\title{
A Drosophila telomer védelmét szolgáló fehérjék fajképzésben betöltött lehetséges szerepének vizsgálata
}

Ph. D. értekezés

Vedelek Balázs

Témavezetők:

Prof. Boros Imre Miklós

Dr. Blastyák András

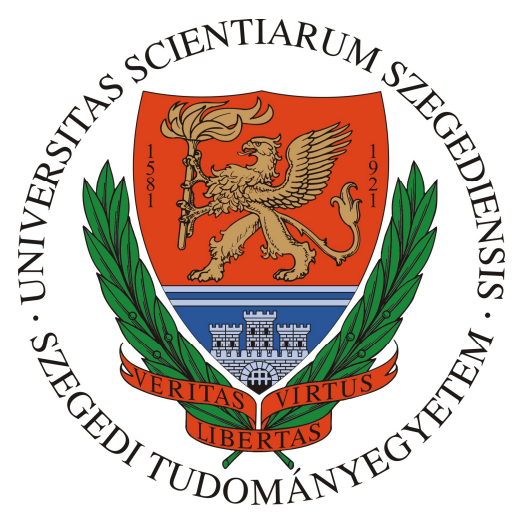

Biológia Doktori Iskola

Biokémiai és Molekuláris Biológiai Tanszék / Biológia Intézet

SZTE TTIK

Szeged, 2017 


\section{Tartalom}

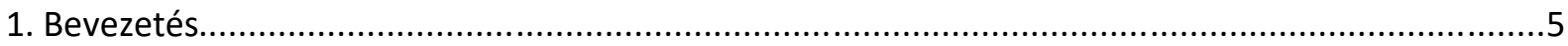

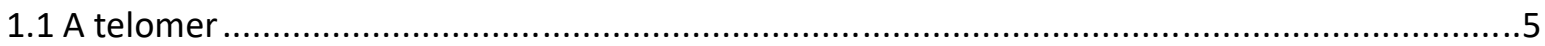

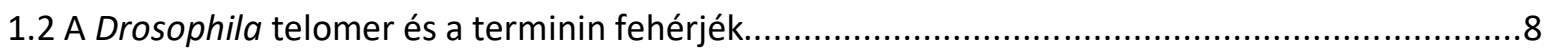

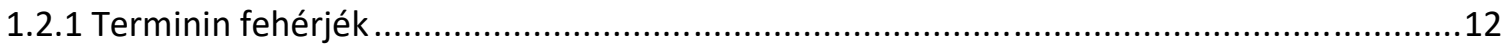

1.3 A fajkeletkezés és a gyors evolúciójú gének szerepe a fajok izolálásában ...............................14

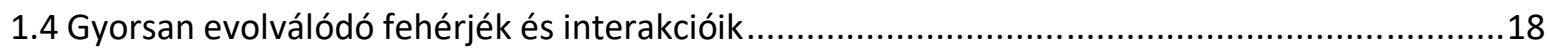

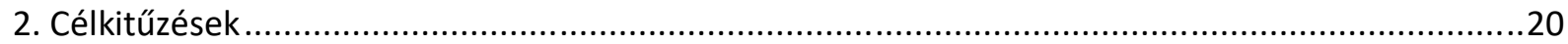

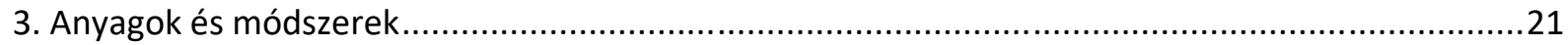

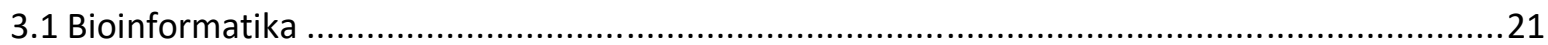

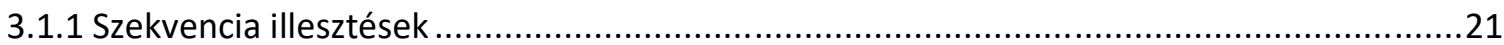

3.1.2 Globuláris-rendezetlen szerkezetek meghatározása.....................................................22

3.1.3 Kodon-illesztések és az evolúció sebességének számítása .............................................22

3.1.4 Három dimenziós térszerkezeti modellek készítése ......................................................22

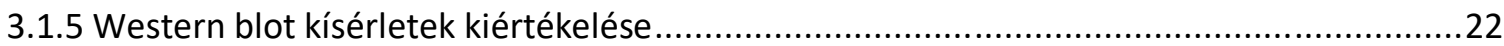

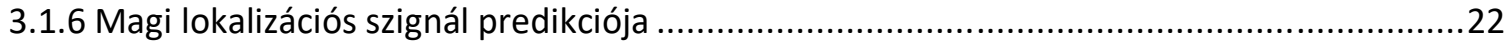

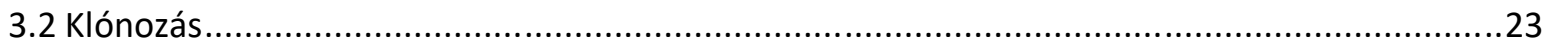

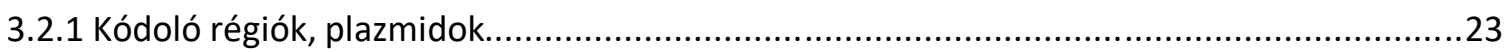

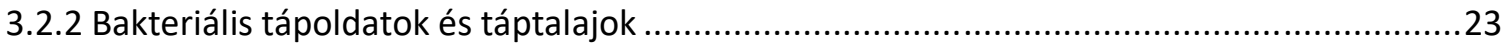

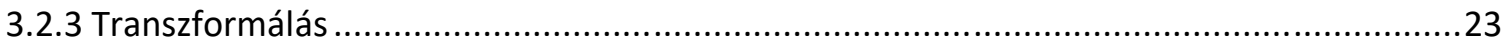

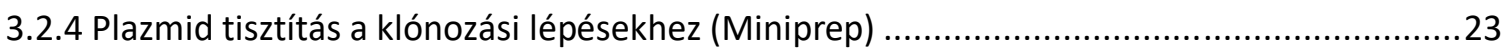

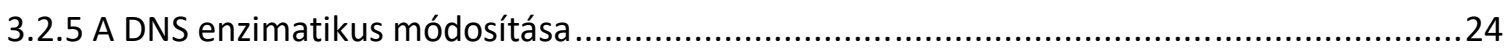

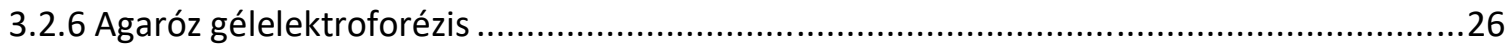


3.2.9 Idegen fehérje expressziót monocisztronos elrendezésben biztosító plazmidok előállítása

3.2.10 Idegen fehérje expressziót policisztronos elrendezésben biztosító plazmidok előállítása 28

3.3 Virális vektor előállítása és fehérje termeltetés rovar sejtekben .29

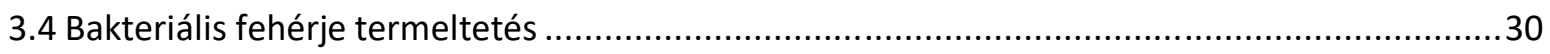

3.5 Sejtek feltárása és a fehérjék oldhatóságának vizsgálata........................................................30

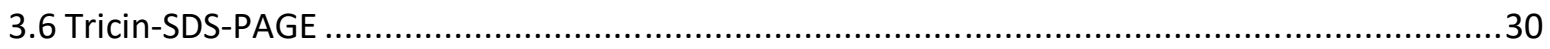

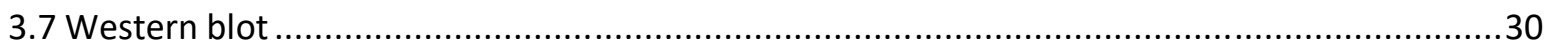

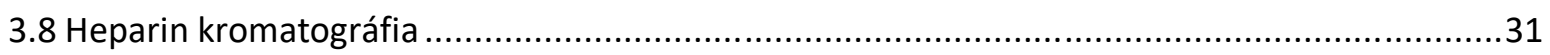

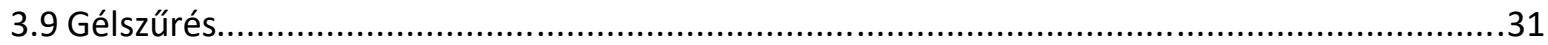

3.10 Peptid mass fingerprinting - tömegspektroszkópia...............................................................31

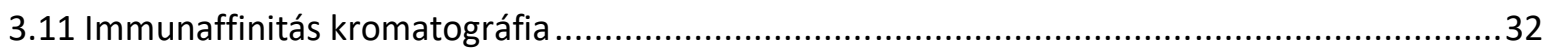

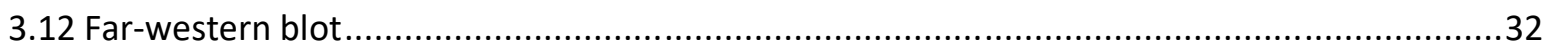

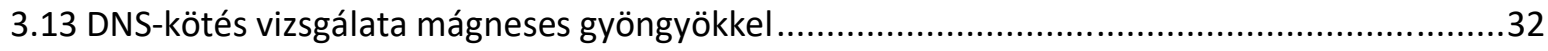

3.14 DNS kötés vizsgálata bioréteg interferencia (BLI) segítségével ...........................................34

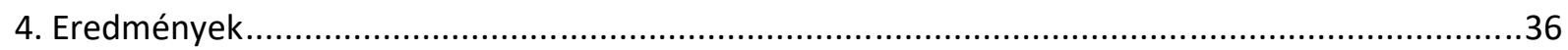

4.1 A terminin fehérjék doménjei evolúciós léptékben gyorsan változnak ...................................36

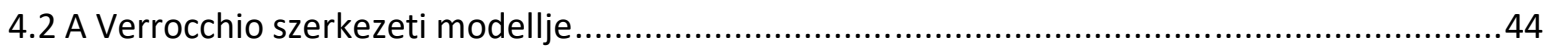

4.3 A terminin fehérjék heterológ expressziója..........................................................................50

4.4 A terminin fehérjék tisztításuk során két alkomplexet formálnak .......................................54

4.5 A D. yakuba Ver és a D. melanogaster DTL hibrid komplexet formálnak.................................58

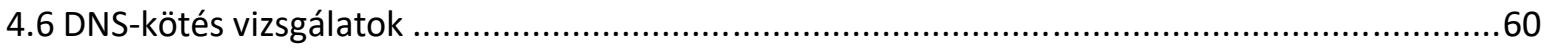


$5.1 \mathrm{~A}$ terminin fehérjék gyorsan változó doménjeiken át alakítanak ki kölcsönhatásokat 65

5.2 A terminin komplex két alkomplexből szerveződik. 66

5.3 A Ver-DTL heterodimer és a fajképzés 68

5.4 A Ver-DTL dimer szerepe a DNS hibajavítás gátlásában .... .70

5.5 Gyors evolúciójú fehérjék a fajképzésen túl .72

6. Köszönetnyilvánítás . .74

7. Irodalomjegyzék. 75

8. Összefoglaló. 87

9. Summary 90

10. Függelékek 93 


\section{Bevezetés}

\subsection{A telomer}

Az eukarióta sejtek számos evolúciós újítást hordoznak a prokarióta sejtekhez képest. Ezek egyike a megnövekedett méretű genom, amely a prokarióták többségétől eltérően nem cirkuláris, hanem lineáris kromoszómákba szerveződik. A lineáris kromoszómák lazább szerkezetű, transzkripciósan aktív eukromatinból és kompaktabb struktúrájú, transzkripciót tekintve kevésbé aktív heterokromatinból állnak. Bár a heterokromatikus régiókról csak ritkán történik transzkripció, ezek mégis fontos elemei a genomnak, például ilyenek a centromerek és a kromoszóma végeken található telomerek is.

A telomerek helyes múködése felel a kromoszóma végek védelméért, így nélkülözhetetlenek a genom stabilitásának megőrzésében [Muller 1938, McClintock 1941, 1942]. A telomer funkciója kettős: egyfelől megakadályozza a DNS hibajavító mechanizmusokat abban, hogy a kromoszóma végeket DNS törésként ismerjék fel, másrészt pedig megoldást jelent a végek replikációjának problémájára. A lineáris kromoszóma DNS replikációja során speciális problémát jelent az, hogy a DNS polimeráz nem tud DNS szintézist indítani, csak már létező nukleinsav láncot folytatni. Az örökítőanyag másolása során ezért a sejt RNS oligonukleotidokat használ a DNS szintézis elindításához. Ezek a rövid nukleotidláncok később eltávolításra kerülnek és helyüket a DNS polimeráz tölti fel. Viszont a lemaradó szálon lévő utolsó RNS molekula eltávolítása után nincs nukleotidlánc, amit a DNS polimeráz folytathatna, így ez a szál minden ciklusban minimum az RNS lánc hosszával megegyező mértékben rövidül [Olovnikov 1971, Watson 1972]. A kromoszóma vég replikáció problémára a legelterjedtebb megoldás az élővilágban egy speciális enzim, a telomeráz használata. A telomeráz egy fehérje és RNS alegységekből szerveződő, reverz transzkriptáz aktivitású enzim, ami az RNS templát segítségével meghosszabbítja az egyébként folyamatosan rövidülő telomer régiót [Greider és Blackburn 1985; Nugent és Lundblad 1998]. A kromoszómális DNS vége így a telomeráz templátjának rövid ismétlődéseiből, illetve további heterokromatikus szerveződésú telomer asszociált szekvenciákból (TAS) áll. Emlősök esetén az ismétlődő szekvencia a „TTAGGG", melyet specifikus fehérjék felismernek és hozzákötődnek [Nugent és Lundblad 1998]. A szekvenciához kötődő fehérjék a telomeráz enzim múködésének szabályozása mellett biztosítják a telomer másik fő funkcióját, azaz meggátolják, hogy a DNS hiba javító mechanizmusok törésként ismerjék fel a kromoszóma végeket és „kijavítsák” azokat, mely folyamat kromoszóma fúziókat eredményezne [Sandell és Zakian 1993, van Steensel és de Lange 1997]. Emberben hat fehérje vesz 
részt közvetlenül a kromoszóma végek épségének védelmében: a TRF1, TRF2, POT1, TPP1, TIN2, és a hRap1, melyek együtt a shelterin komplexet alkotják [Liu et al. 2004, összefoglalva: Palm és Lange 2008, Diotti és Loayza 2011]. Ez a komplex alakítja ki a telomerekre jellemző speciális struktúrát, a telomerikus hurkot (t-loop) [Griffith et al. 1999]. A hurok azáltal jön létre, hogy a kromoszómák egyes-szálú 3’ túlnyúló vége visszahajlik a kettős-szálú régió felé és leszorítja a vele azonos szekvenciájú szálat, hibridizálva annak komplementer szakaszával [összefoglalva: de Lange 2004] (1. ábra, B panel). A t-hurok mellett egy másik jellegzetes DNS szerkezet, a G-kvadruplex is kialakulhat a kromoszóma végeken [Williamson 1994, Mullins et al. 2016] (1. ábra, C panel). Ennek jelenléte nem zárja ki a t-hurok formálódását (1. ábra, D panel), azonban az, hogy in vivo pontosan milyen szerkezetet vesz fel a telomer, még nem tisztázott [Oganesian és Karlseder 2009].

A shelterin fehérjék közül a TRF1 [Bianchi et al. 1997] és a TRF2 [Bilaud et al. 1997] a kettős-szálú DNS-kötésért felel, míg a POT1 az egyes-szálú DNS-t köti [Baumann és Cech 2001]. Ennek megfelelően, hiányukban a kettős-szálú vagy egyes-szálú töréseket felismerő hibajavítási mechanizmusok aktiválódnak. A TPP1 fehérje nem köt DNS-t, viszont ez a protein felel a POT1 shelterin komplexhez való kötődéséért [Xin et al. 2007] (1. ábra, A panel). A TIN2 és a hRap1 fehérjék ugyancsak elengedhetetlenek a komplex szerveződéséhez és működéséhez [Kim et al. 1999, Nandakumar et al. 2012, Li et al. 2000]. 
A)

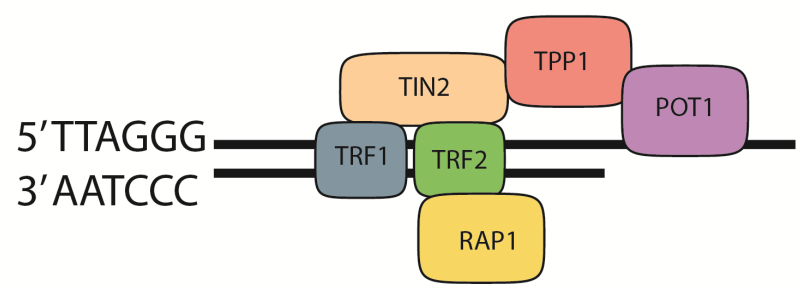

B)

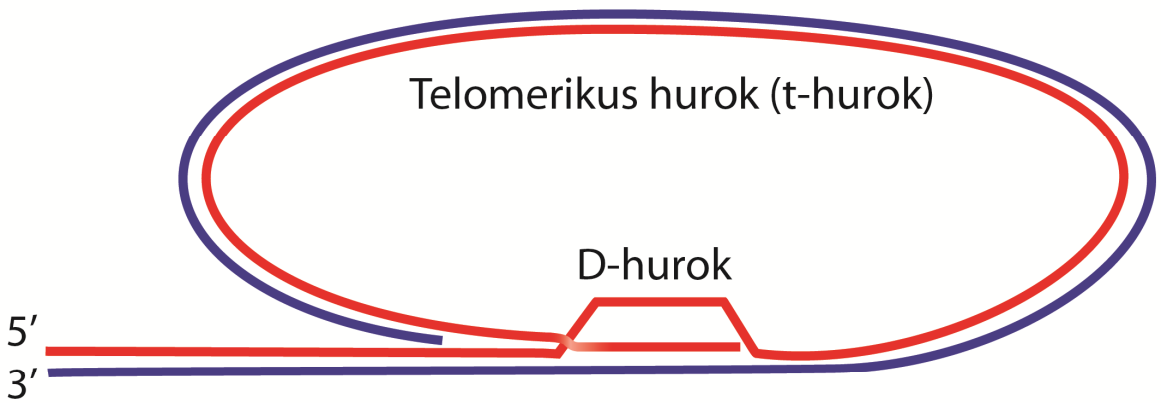

C)

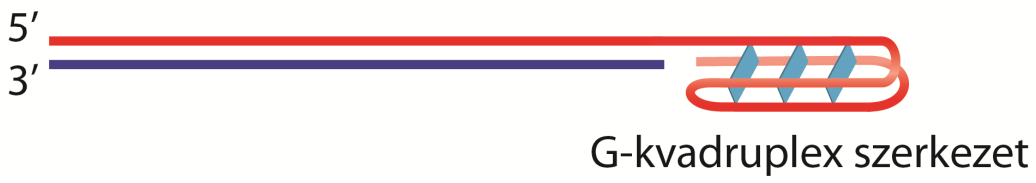

D)

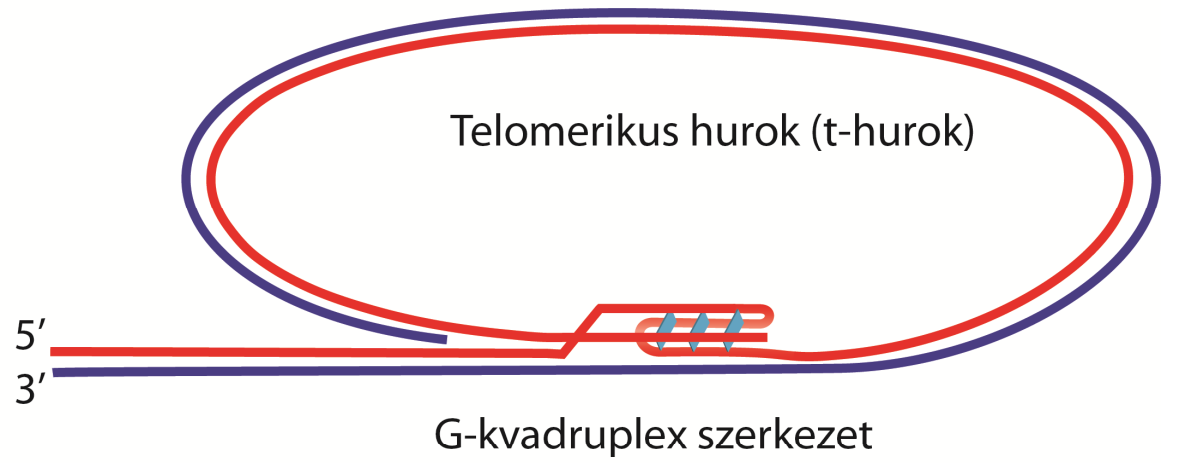

1. ábra: A kanonikus telomer „cap” szerkezetének sematikus ábrázolása

(A) A humán shelterin komplex tagjai és a köztük lévő kölcsönhatások. A fehérjék a "TTAGGG” szekvenciát ismerik fel, a TRF1 és TRF2 kettős-szálú DNS-t kötnek, míg POT1 az egyes-szálú túlnyúló véget. (B-D) A kromoszóma végekre jellemző struktúrák: a telomerikus hurok és a G-kvadruplex. A telomerikus hurkot elektronmikroszkóp segítségével fedezték fel [Griffith et al. 1999], azonban in vivo létezése vitatott. A telomer 3' túlnyúló szálának G-kvadruplex szerkezete bizonyított, és rákterápiás célpontként fontos a gyógyászatban [Hurley et al. 2000, Gomez et al. 2004, Bidzinska et al. 2013]. A shelterin fehérjék nélkül nem alakulnak ki ezek a struktúrák [Oganesian és Karlseder 2009, Mullins et al. 2016]. 
A telomer fenntartásában az említett fehérjéken kívül más proteinek is részt vesznek. Elsőként említendők a DNS javítási mechanizmusok szereplői, az ATM és ATR útvonalból ismert fehérjék (Mre11, Rad50, Nbs, ATM, ATR, ATRIP, ku70/ku80) [összefoglalva: Lydall 2009]. A guaninban és citozinban gazdag telomerikus DNS replikációjához különböző helikázok, nukleázok és kromatin szerkezetet változtató faktorok is szükségesek [Oganesian és Karlseder 2009, Diotti és Loayza 2011, Stewart et al. 2012]. A telomer fenntartás bonyolultságát fokozza továbbá, hogy a heterokromatinba szerveződő telomerikus ismétlődésekről RNS molekulák íródnak át, mely RNS féleségek is részt vesznek a telomer funkció kialakításában [Azzalin et al. 2007, Deng et al. 2009]. Az emlős telomer fenntartásában részt vevő fontosabb fehérjéket a 2. ábra foglalja össze (2. ábra, A panel).

A kromoszóma végek fenntartása azonban nem csak az eddig ismertetett módon lehetséges. Bizonyos esetekben a telomer meghosszabbodása végbemehet homológ rekombinációval. Ilyen folyamat zajlik például egyes emlős sejtvonalakban [Rendel et al. 1997] és rákos sejtekben [Rendel 2003]. Találunk a kanonikustól eltérő telomer szerkezetet és múködést, például hagymafélékben, selyemhernyókban és egyes légyfajokban, közöttük Drosophila-félékben is [összefoglaló: Fulcher 2014]. Laborunkban az ecetmuslicával (Drosophila melanogaster) foglalkozunk, mely az egyik legrégebb óta használt modellorganizmus [Morgan 1903, Carpenter 1905]. Az elmúlt több mint száz év alatt hatalmas genetikai eszköztár és tudás halmozódott fel, melynek segítségével nem pusztán a Drosophila melanogasterröl nyertünk információt, de lehetővé vált minden eukariótában, köztük az emberben lejátszódó molekuláris folyamatok jobb megértése is. Ezért, bár a Drosophilákban a telomer fenntartása bizonyos mértékben eltér az emberétől, annak vizsgálata a fennmaradó hasonlóságok miatt mégis indokolt.

\subsection{A Drosophila telomer és a terminin fehérjék}

A Drosophila melanogasterben és a vele rokon fajokban nincsen telomeráz enzim. A kromoszóma végek meghosszabbítása ezekben az állatokban retrotranszpozícióval történik [Cenci et al. 2003, Pardue és DeBaryshe 2003, Villasante et al. 2007, 2008]. A retrotranszpozonok mozgékony genetikai elemek, melyek a DNS alapú transzpozonoktól eltérő módon mozognak a genomban. A retrotranszpozíció során a retrotranszpozonról RNS molekula képződik, mely a retrovírusokhoz hasonlóan kódol egy reverz transzkriptáz enzimet. A reverz transzkriptáz az RNS molekuláról egy DNS másolatot készít, mely képes beépülni a genomba. Drosophila melanogaster telomerein, a reverz transzkripció során a retrotranszpozon mRNS-ek poli-A végükkel a kromoszóma végekhez 
csatlakoznak, majd a telomerázhoz hasonlóan, a transzpozon eredetú reverz transzkriptáz meghosszabbítja a kromoszóma 3' végét [Biessmann et al. 1992].

A folyamatban három specifikus, csak a kromoszóma végek kialakításában szerepet játszó retrotranszpozon vesz részt, a HeT-A [Biessmann et al. 1990], a TART [Levis et al. 1993], és a TAHRE [Abad et al. 2004]. A Drosophila telomerikus régiója ennek megfelelően ezen retrotranszpozonok és 5’ csonkolódott formáik ismétlődéseiből szerveződik (HTT-array). A retrotranszpozon ismétlődések mellett a telomer részét képező szubtelomerikus régiók (telomer asszociált szekvenciák - TAS), a kanonikus telomerekhez hasonlóan, ebben az esetben is erősen heterokromatikus szerveződésűek. A transzpozonok többsége HeT-A és TART, míg TAHRE elemből átlagosan egy kópia található a genomban [Abad et al. 2004]. A TART és a TAHRE elemek két nyitott leolvasási keretet tartalmaznak, az első a GAG fehérjét kódolja, míg a második a reverz transzkriptáz enzimet. A három közül leggyakoribb HeT-A transzpozon viszont csak GAG fehérjéket kódol, így múködéséhez szükség van a TART vagy TAHRE elemek reverz transzkriptázára [Biessmann et al. 1992].

Mivel a retrotranszpozíció közel véletlenszerű esemény, egyes Drosophila populációk között nagy eltérések lehetnek a telomerek hosszában. Az is előfordulhat, hogy a retrotranszpozon ismétlődések teljesen hiányoznak, ilyen eseteket találhatunk természetes populációkban vagy laboratóriumi törzsek között is [Mechler et al. 1985, Mason et al. 2004]. Ezek a törzsek életképesek, ami a telomer alternatív meghosszabbodását lehetővé tevő, a már említett homológ rekombináción alapuló mechanizmus fontosságára utal [Mason és Biessmann 1995, Capkova Frydrychova et al. 2008]. A kromatin szerkezet összefüggésben van a telomer hosszával, mert a retrotranszpozíció valószínűsége a transzpozonok transzkripciójának függvénye, tehát a telomerikus régiók kondenzáltságának csökkenése a transzpozíciók számának növekedését eredményezi. Ezt a jelenséget figyelhetjük meg a tel mutáns esetében, ahol jelentősen megnő a telomer régiók hossza [Siriaco et al. 2002]. A túl hosszú telomer csökkenti a nőstény legyek fertilitását, így a retrotranszpozon transzkripciójának pontos szabályozása nem csak a telomer végek elvesztése miatt fontos [Török et al. 2007, Walter et al. 2007].

A rövid ismétlődésekből álló kanonikus telomer szerveződésétől eltérően, Drosophilában a retrotranszpozicióval kialakuló kromoszóma végek nagy szekvenciaváltozatosságot mutatnak. A szekvenciaváltozatosság miatt kizárt, hogy a specifikus szekvenciát felismerő shelterin komplex múködőképes legyen ecetmuslicában. Azonban mivel mégsem tapasztaljuk a kromoszómák összetapadását, ami a kromoszóma végek védelméért felelős komplex hiányára utalna, egy shelterinnel azonos funkciójú komplex jelenlétére következtethetünk. A feltételezett komplex 
tagjainak azonosítása klasszikus genetikai módszerekkel történt. Több olyan mutáns izolálása is sikeres volt, melyekben a lárvák mitotikusan osztódó neuroblasztjaiban hibás volt a telomer capping, azaz gyakoriak voltak a kromoszóma fúziók. A genetikai analízis eredményeként sikerült azonosítani a telomer funkcióban résztvevő egyéb gének mellett, a kromoszómavégek védelméért felelős géneket is. Ezeknek a termékei a shelterinnel analóg fehérjekomplexet alkothatják, melyet termininnek neveztek el [Raffa et al. 2011]. A hipotetikus terminin komplex négy telomer specifikus fehérjéből (HOAP, HipHop, Ver, DTL) és a heterokromatinban gyakran előforduló HP1 fehérjékből áll. A shelterintől eltérően a terminin szekvenciától függetlenül képes a DNS-hez kötődni [Cenci et al. 2005; Mason et al. 2008; Raffa et al. 2013]. A terminint alkotó fehérjék, a HP1-et kivéve, csak a telomerek fenntartásában játszanak szerepet.

A terminin fehérjéken kívül a Drosophilában is számos további fehérje szükséges a kromoszóma végek kialakításához és fenntartásához. A DNS javítási mechanizmusok résztvevői, akárcsak a telomerázzal kialakuló telomerek esetén, a Drosophila retrotranszpozicióval létrejött telomereinek védelmében is fontos szereppel bírnak. Így az ATM és az Mre11-Rad50-Nbs (MRN) komplex tagjainak hiányában a telomer múködés hibájára utaló kromoszóma fúziókat figyelhetünk meg [Ciapponi et al. 2004, 2006, Komonyi et al. 2009]. Drosophilában az ATR és ATRIP fehérjék mutációja esetén nem tapasztalunk telomer fúziókat, viszont ATM és ATR kettős mutánsokban súlyosabb fenotípus jelenik meg, mint az ATM mutánsokban, ami részlegesen átfedő funkcióra utal [Bi et al. 2005]. Ezen fehérjéken kívül fontos, a Drosophila-félékben konzervált proteinek még az UbcD1 ubikvitin ligáz [Cenci et al. 1997], a Woc transzkripciós faktor [Raffa et al. 2005] és a kis RNS-ek (piRNS) biogenezisében részt vevő Armi és Aub fehérjék, melyek hiánya szintén kromoszóma fúziót eredményez [Khurana et al. 2010]. A telomer múködésének feltárása még nem teljes, a közelmúltban további fehérjéket fedeztek fel, melyek nemcsak Drosophilában, de emberben is jelentőséggel bírnak (2. ábra, B panel) [Singh és Lakhotia 2015, Cenci et al. 2015, Yamaki et al. 2016, López-Panadès és Casacuberta 2016, Cipressa et al. 2016]. 


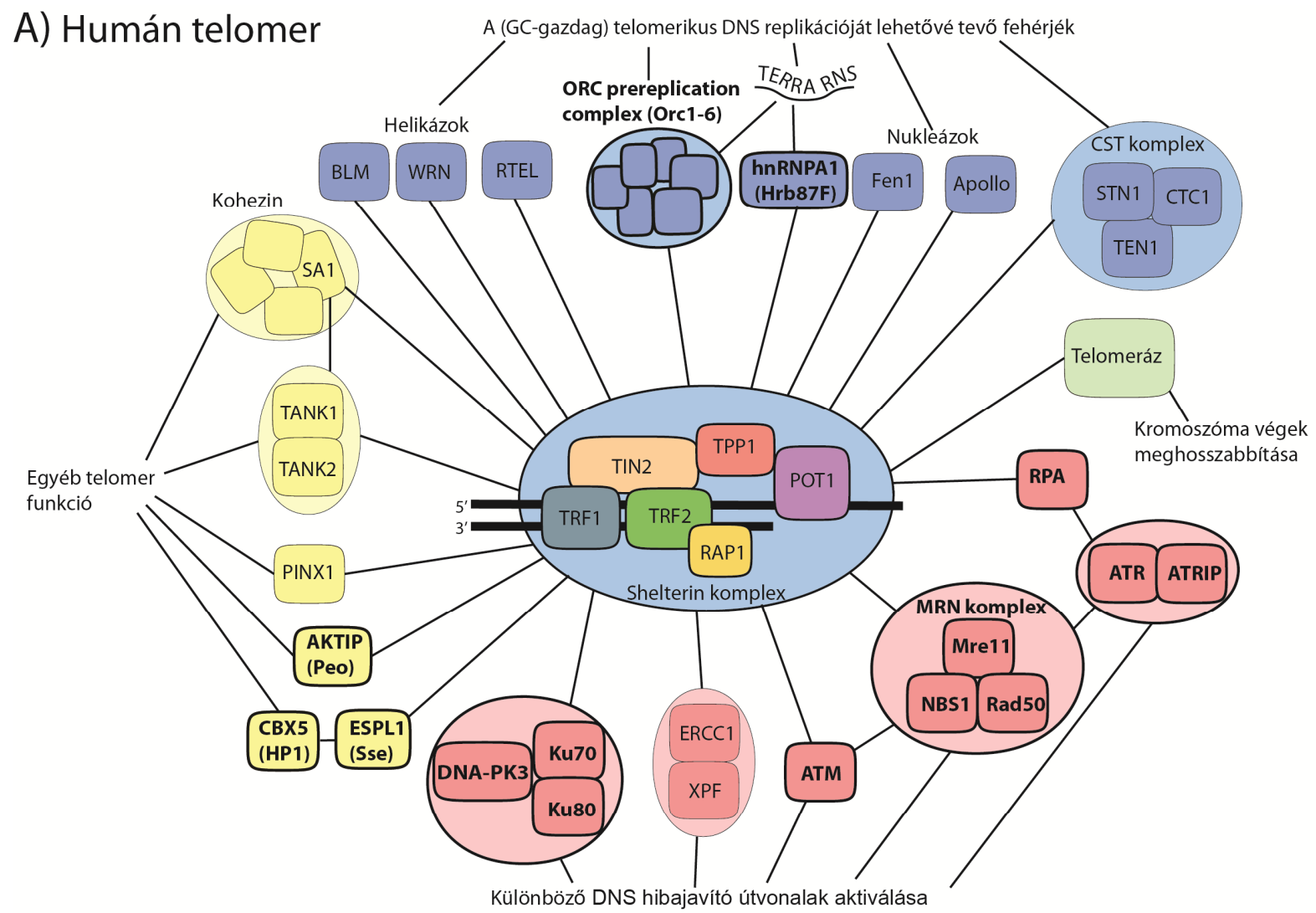

B) Drosophila telomer

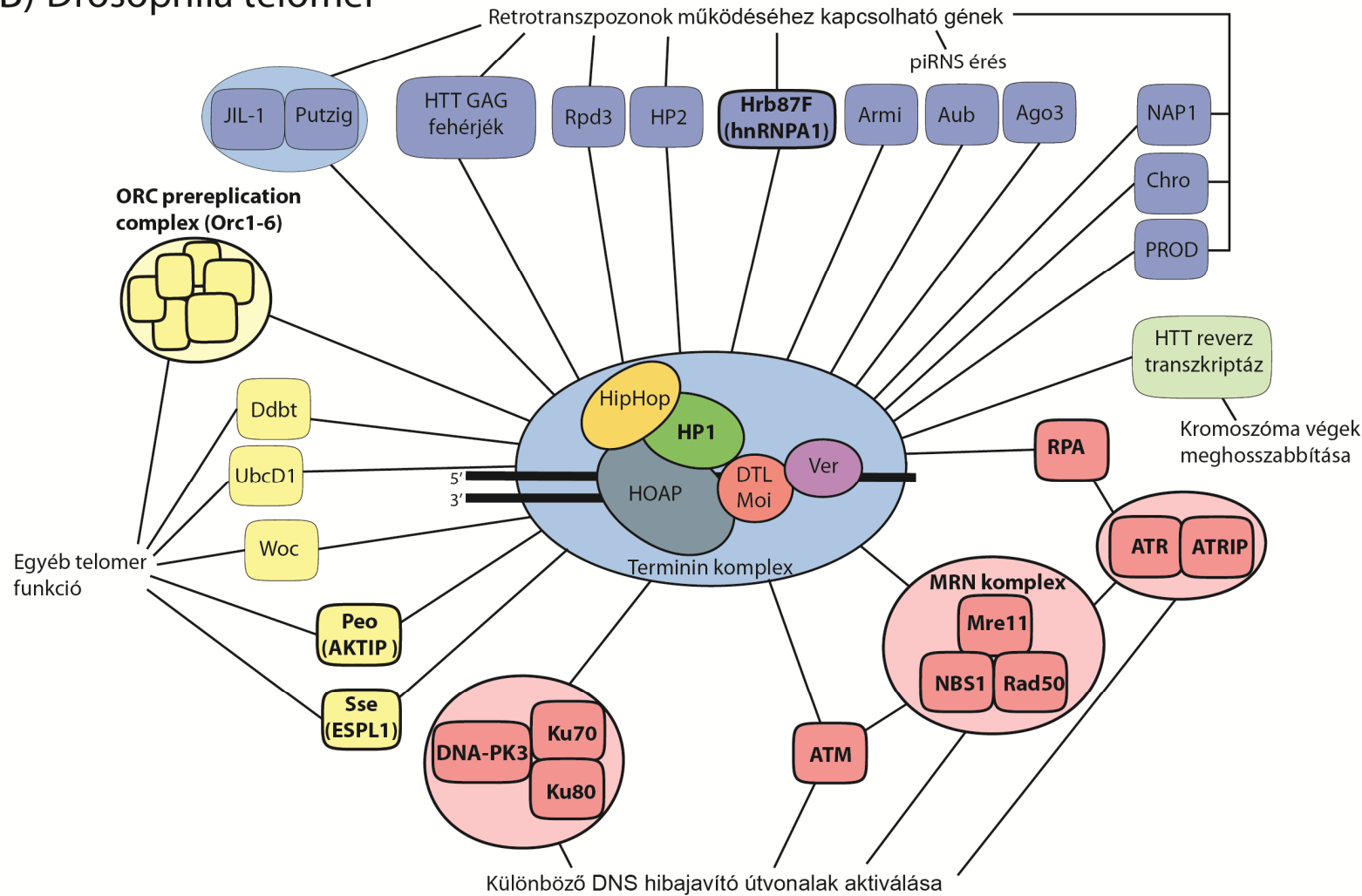

2. ábra: A humán és a Drosophila telomer fenntartásban részt vevő fehérjék és kapcsolatianak vázlatos ábrája

$A z$ ember $(A)$ és a Drosophila (B) telomer fenntartásban részt vevő fontosabb ismert fehérjék. $A$ shelterin $(A)$ és a terminin (B) komplexek az ábrák központjában láthatóak kék körben. A shelterin és terminin fehérje 
komponenseik elhelyezkedése a feltételezett komplexen belüli kapcsolataikat mutatják. A kék körön kívül azokat az ismert fehérjéket jelöltük, melyek részt vesznek a telomer hosszának szabályozásában, illetve a DNS hibajavítási útvonalakban. A Drosophila és humán telomer fenntartásban részt vevő fehérjék közül számos megegyezik (vastagon szedve). Mindkét esetben zöld szín jelöli a kromoszómák meghosszabbítását végző enzimet és piros a DNS hibajavításhoz kapcsolható fehérjéket. A humán és Drosophila telomer fenntartásban részt vevő fehérjék közti fő különbségeket visszavezethetjük az eltérő fenntartási mechanizmusokra: emberben a „GC” gazdag szekvenciák replikációja (kék) [Cenci et al. 2005, Deng Z et al. 2007, Oganesian és Karlseder 2009, Diotti és Loayza 2011, Stewart et al. 2012, Burla et al. 2015, Cipressa et al. 2016], míg Drosophilában a retrotranszpozonok transzkripciójának szabályozása (kék) jelenti a fő eltérést [Raffa et al 2011, 2013, Burgio et al. 2011, Silva-Sousa et al. 2012, Takács et al. 2012, Singh és Lakhotia 2015, Cenci et al. 2015, Yamaki et al. 2016, López-Panadès és Casacuberta 2016, Cipressa et al. 2016]. Sárgával jelöltük az egyéb telomer funkciókat végző fehérjéket.

\subsubsection{Terminin fehérjék}

Míg emberben a shelterin komplex felelős a kromoszóma végek DNS javító mechanizmusok előli elrejtéséért és hosszuk szabályozásáért, addig Drosophilában a terminin fehérjék látják el ezt a funkciót. A HP1, a HOAP, a HipHop, a Ver és a DTL proteinek a kromoszómák végein találhatóak és hiányukban kromoszóma fúziókat figyelhetünk meg [Fanti et al. 1998, Cenci et al. 2003, Raffa et al. 2009, Gao et al. 2010, Raffa et al. 2010]. Immunprecipitációs kísérletek során ezek a fehérjék együtt tisztulnak, ezért feltételezzük, hogy komplexet alkotnak [Raffa et al. 2011]. A komplex léte azonban mindmáig hipotetikus, szerveződése és sztöchiometriája nem ismert. Az öt terminin fehérjéből négy, a HOAP, a HipHop, a Ver és a DTL jelentősen kisebb konzerváltságot mutat a Drosophila fajok között, mint más Drosophila proteinek, ami meglepő, hiszen az alapvető sejtmúködéshez köthető fehérjék általában konzerváltak. Még meglepőbb, hogy ezek a változékony fehérjék olyan konzervált útvonalak szereplőivel közösen látják el a funkciójukat, mint a DNS hibajavító mechanizmus proteinjei (2. ábra). A fehérjék alacsony konzervációját a fehérjék gyors evolúciójaként értelmezzük.

A következőkben a terminin fehérjéket egyenként tekintem át, csak legfontosabb ismert szerepüket, valamint egymással és DNS-sel mutatott kapcsolatukat említve.

\section{DTL/Moi}

DTL (Drosophila Telomer Loss, másik nevén Modigliani) kisméretű protein (21kDa), mely immunprecipitációs kísérletek alapján kölcsönhat a HOAP és a HP1 fehérjékkel [Raffa et al. 2009]. A HOAP szükséges a DTL telomeren történő lokalizációjához [Raffa et al. 2009]. DTL mutánsban az egyes-szálú DNS törést felismerő ATR DNS hibajavító mechanizmus aktiválódik, mely kromoszóma fúziókat eredményez [Komonyi et al. 2009].

Érdekesség, hogy a DTL a Tgs1 fehérjék egy bicisztronos mRNS-ről képződnek, így közös transzkripciós szabályozás alatt állnak. A Tgs1 egy trimetil-guanozin-szintázt kódol, ami nem vesz részt a telomer fenntartásban [Komonyi et al. 2005]. 
Ver

Verrocchio (Ver) egy 24 kDa méretű fehérje melynek hiányában, - akárcsak a DTL esetén - az ATR DNS hibajavító útvonal aktiválódik. Immunprecipitációs kísérletek során a Ver a HOAP és a DTL fehérjékkel hat kölcsön [Raffa et al. 2010].

HOAP

HOAP (HP1-ORC Associated Protein) a HP1-gyel való kölcsönhatása után kapta a nevét [Cenci et al. 2003]. HOAP-ot a caravaggio (cav) gén kódolja. Ez a 60 kilodalton körüli fehérje a legnagyobb a terminin fehérjék között, és központi szerepet lát el a telomer szerveződésében. Hiányában a HipHop, a DTL és a Ver fehérjék sem lokalizálódnak a telomeren [Gao et al. 2010, Raffa et al. 2009, 2010], továbbá a DNS javító mechanizmusok aktiválódnak és a sejtciklus megáll [Musarò et al. 2008]. HOAP kettős-szálú DNS-hez kötődik, funkciójában a TRF1 és TRF2 shelterin fehérjékre hasonlít.

Érdemes megemlíteni, hogy HOAP nemcsak aminosav szinten mutat felgyorsult evolúciót, hanem a cav gén is többször duplikálódott a Drosophila törzsfejlődés során [Dubruille et al. 2012].

HipHop

HipHop (HP1-HOAP interacting protein) neve a HOAP-pal és a HP1-gyel való kölcsönhatására utal. Ez a megközelítően $35 \mathrm{kDa}$ méretű fehérje és a HOAP kölcsönösen stabilizálják egymást a telomer végeken, ezen felül mindkettő lokalizációja az MRN és ATM komplexek által szabályozott [Gao et al. 2010]. HipHop akárcsak HOAP az evolúció során többször is duplikálódott [Dubruille et al. 2012]. Egy ilyen paralóg Drosophila melanogasterben a K81, mely a ritka apai hatású gének egyike [Yasuda et al. 1995]. K81 a csíravonalban HipHop helyett épül be a kromoszómák végére [Gao et al. 2011].

HP1

Szigorúan véve, a 28 kDa méretű HP1 (Su(var)205) nem nevezhető terminin fehérjének, hiszen konzervált fehérje [Clark és Elgin 1992] és egyéb szerepe is ismert, mint például a heterokromatin szabályozása [Fanti et al. 1998, Savitsky et al. 2002, Perrini et al. 2004, Vermaak és Malik 2009]. Azonban HP1 szoros kölcsönhatásba lép a HOAP és a HipHop fehérjékkel, ezért a komplex részének tekintjük [Badugu et al. 2003, Gao et al. 2010]. HP1 a heterokromatin fenntartását a H3 hiszton metilált kilencedik lizinjével (H3K9me) történő kölcsönhatás révén fejti ki [Lu Xingwu et al. 2013].

Habár a HP1 maga egy konzervált fehérje, a fehérjecsalád, amibe tartozik, változatos evolúciós történettel rendelkezik [Levine et al. 2012.] 
A DTL, a Ver, a HOAP és a HipHop különböző Drosophila fajokban jelentősen nagyobb szekvencia különbséget mutatnak, mint más Drosophila fehérjék, mely jelenség több kérdést is felvet [Raffa et al. 2011]. Figyelembe véve a fehérjék fontos funkcióját, elképzelhető, hogy a tapasztalt különbségek nem a fajok szétválása miatt alakultak ki, hanem a fajok szétválásának egyik hajtóerejeként szolgálhattak. Hogy jobban megértsük ezt a feltevést, tekintsük át, hogy milyen mechanizmusokat ismerünk a populációk és a molekulák szintjén, melyek új fajok kialakulásához vezethetnek.

\subsection{A fajkeletkezés és a gyors evolúciójú gének szerepe a fajok izolálásában}

Számos elmélet foglalkozik a fajképzés mechanizmusával ökológiai, populációgenetikai megközelítésben éppúgy, mint molekuláris szinten [Gavrilets 2003, Kulathinal és Singh 2008; Nei és Nozawa 2011].

Ahhoz, hogy a fajképzésről beszélhessünk, definiálnunk kell a faj fogalmát, azonban, mivel a faj egy mesterséges fogalom, a legjobb definíció sem használható minden aspektusban maradéktalanul. Ezért több tudományág is megalkotta a saját, az adott területen jól használható faj definícióját (pl.: ökológiai fajfogalom, genetikai fajfogalom, filogenetikus fajfogalom, fenetikai fajfogalom, felismerési fajfogalom). A klasszikus biológiai definíció szerint a faj a potenciálisan ivaros szaporodással termékeny utódot létrehozni képes élőlények csoportja, melyek más hasonló csoportoktól elkülönülnek [Mayr 1942]. A továbbiakban ezt a faj fogalmat használom.

A fajkeletkezést filogenetikai szempontból két típusra oszthatjuk, az anagenezisre és kladogenezisre. $A z$ anagenezis során nem jön létre új elágazás a filogenetikai fán, ám az ősi alakok a fiataloktól oly mértékben különböznek, hogy nem tekintjük őket egy fajnak. A kladogenezis során viszont új elágazás jön létre a filogenetikai fán, azaz egy fajból kettő lesz. A kladogenezis általában populációk elkülönülésével kezdődik, melyek eltérő irányba fejlődve idővel különböző fajokat alkotnak. A kladogenezisnek négy klasszikus típusát ismerjük, melyeket a populációk mérete és az elkülönültség foka alapján határozunk meg (3. ábra).

Allopatrikus fajkeletkezésről beszélünk, ha egy populáció két nagyobb populációra esik szét, például földrajzi izoláció vagy migráció miatt [Hoskin et al. 2005]. Az izoláltság révén a két populációban eltérő mutációk halmozódnak fel, végül nem lesznek képesek egymással szaporodni, így két faj alakul ki.

A peripatrikus fajkeletkezés klasszikus esete egy sziget kolonizálása. A szigetre egy kisebb populáció érkezik, mely genetikailag kevésbé diverz, ezért erős palacknyak hatás érvényesül rajta. Ilyenkor a természetes szelekció mellett jelentős genetikai sodródás is érvényesül, mely miatt olyan allélok 
maradhatnak fenn, amelyek egy nagy populációban elvesznének [Templeton 1980]. Ebben az esetben tehát az új mutációk könnyen fennmaradhatnak, melyek gyors reprodukciós izolációhoz vezethetnek.

A parapatrikus fajkeletkezés hasonlít a peripatrikusra, azonban ebben az esetben a két populáció nem szigetelődik el teljesen. Általában a kiindulási populáció élőhelyének megváltozása idézi elő a parapatrikus fajkeletkezést [Gavrilets 2003].

A negyedik típus a szimpatrikus fajkeletkezés, amikor nincs földrajzi elkülönülés és az élóhely is állandó, mégis új faj alakul ki a kiindulási populáción belül. A szimpatrikus evolúció ritka jelenség. Így keletkeztek például a Darwin pintyek (Geospiza fajok) ahol a fajkeletkezés a különböző típusú táplálékhoz való alkalmazkodás során működik (szétválasztó szelekció). Egy másik példa bizonyos pálma fajok keletkezése [Savolainen et al. 2006].

\section{Allopatrikus Peripatrikus Parapatrikus Szimpatrikus}

\section{Eredeti populáció}
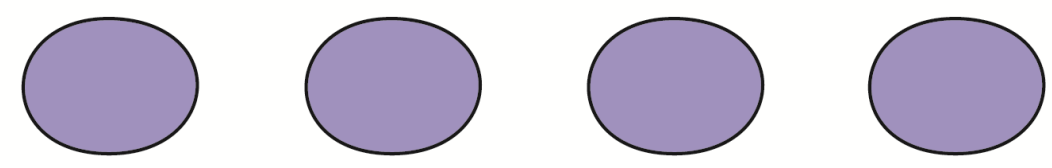

Fajképződés
első lépése
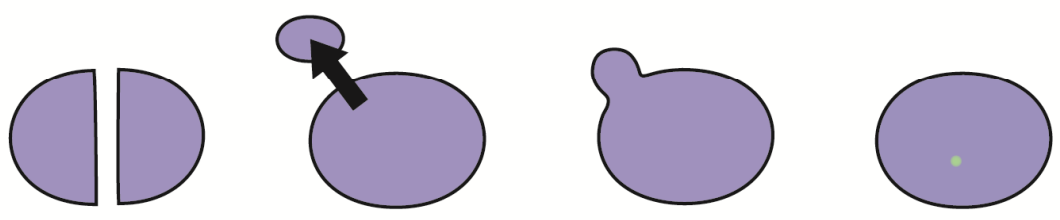

Akadály képződés

Megjelenés új élőhelyen

Genetikai változás

\section{Reprodukciós izoláció kialakulása}
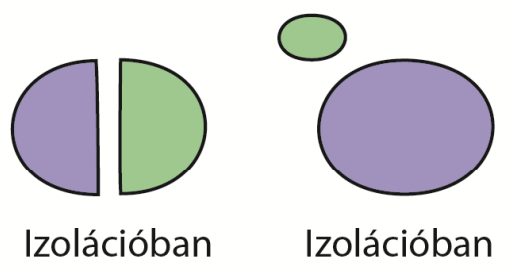

Izolációban

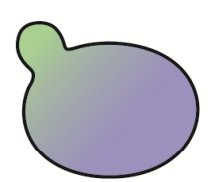

Szomszédos élőhelyen

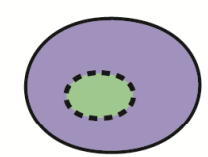

Populáción belül

\section{Fajok elkülönülése}
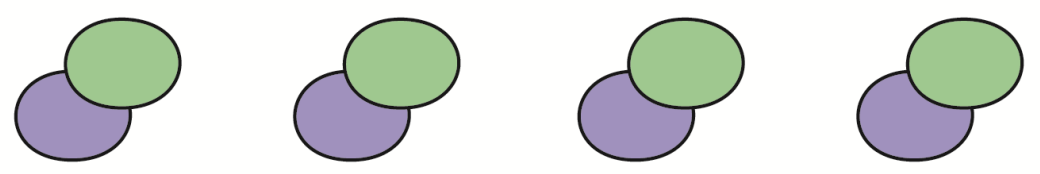

\section{3. ábra: A fajkeletkezés mechanizmusait földrajzi elkülönülés és populáció méret alapján bemutató ábra} Az allopatrikus és peripatrikus fajkeletkezés során a populációk elkülönülnek egymástól, míg parapatrikus és szimpatrikus fajkeletkezés során földrajzi izoláció nem figyelhető meg.

(Krempels ábrája alapján [Krempels 2006]) 
Az allopatrikus és peripatrikus fajkeletkezés során a földrajzi elkülönültség következtében a populációk egymástól függetlenül fejlődhetnek. A földrajzi elkülönülést a populációk között lévő földrajzi egység (hegy, völgy, tenger vagy egyéb) esetleg a migráció teszi lehetővé, melyeket külső reprodukciós korlátoknak nevezünk. A külső korlátok mellett léteznek egyéb mechanizmusok is, melyek a parapatrikus és szimpatrikus fajkeletkezés sebességét növelhetik. Ezek a mechanizmusok az élőlények genetikai sajátosságaiból adódnak, ezért belső reprodukciós korlátoknak nevezzük őket. A belső reprodukciós korlátokat további két csoportba soroljuk. A pre-zigotikus korlátok meggátolják a párzást, míg a poszt-zigotikus korlátok meggátolják hibrid utód létrejöttét, vagy a hibrid utódok sterilitását okozzák. Pre-zigotikus korlát például az udvarlási viselkedést (afrikai Nagy-tavak sügérjei [Boughman 2002]) vagy a genitáliák formáját (rovarok) meghatározó gének [Masly 2012]. Bármilyen genetikai különbség múködhet poszt-zigotikus korlátként, amennyiben az utódok életképességét vagy fertilitását csökkenti. Az ilyen eltérések gyakran érintik a kromoszómák helyes múködését.

A kromoszóma mutációk jellemzően reprodukciós korlátként funkcionálhatnak [Ayala és Coluzzi 2005]. Azonban a kromoszóma átrendeződések méretétől és pozíciójától függ az, hogy milyen mértékben járulnak hozzá a poszt-zigotikus izolációhoz. Ennek elsődleges oka, hogy rekombinációs események során különböző mennyiségű és fontosságú gén elvesztését vagy duplikációját eredményezhetik. A kromoszóma mutációk poszt-zigotikus korlátként való múködésének pontos mechanizmusa fajonként eltérő lehet, leírásukra több modell is született, melyet Reiseberg gyújtött össze [összefoglalva: Reiseberg 2001].

A kromoszóma mutációk mellett poszt-zigotikus korlátként működhetnek gének is. A homológ rekombináció folyamatát kiaknázó faj-izolálási mechanizmust írtak már le egérben. A speciációért felelős fehérje a PRDM9 [Mihola et al. 2009, et al. Oliver 2009]. Funkcióját tekintve specifikus szekvenciánál köti a DNS-t és kijelöli a rekombináció kezdőpontjait. A fehérje DNS-kötő doménjében tapasztalt gyors evolúció miatt, eltérő fajokban eltérő szekvenciát ismer fel, így eltérő mintázatot eredményez a rekombináció kezdőpontjainak eloszlásában. Amennyiben a vizsgált fajokat keresztezzük, a rekombináció lezajlása után, a forrópontok különböző elhelyezkedése miatt, a keletkező kromoszómák egyenlőtlen méretűek lesznek. A felismerési helyek aszimmetriája miatt gének vagy egész kromoszóma régiók veszhetnek el, mutálódhatnak, vagy duplikálódhatnak, mely végül letalitáshoz vezet.

A PRDM9 poszt-zigotikus korlátként való múködését az teszi lehetővé, hogy gyors evolúciót mutat, így rövid idő alatt új felismerési szekvenciát fejleszthet. 
Szintén gyors evolúciót mutató, ismert izolációs gének Drosophila melanogasterben és Drosophila simulansban az Lhr (Lethal hybrid rescue) és a Hmr (Hybrid male rescue) gének [Brideau et al. 2006, 2011, Satyaki et al. 2014], melyek a centromer kialakításában játszanak fontos szerepet. Az Lhr és Hmr fehérjék nem minden fajban múködnek speciációs korlátként. Például a $D$. melanogaster nőstények keresztezése $D$. simulans hímekkel nem eredményez életképes hím utódokat, míg $D$. simulans nőstények keresztezése D. melanogaster hímekkel igen [Sturtevant 1920]. A tapasztalt különbségekért az X kromoszómán található $H m r$ gén felelős, azaz $D$. melanogaster $H m r$ gén hibrid letalitást okoz, míg a D. simulans Hmr gén nem [Barbash et al. 2004]. A letalitás hátterében feltehetően a fehérjék fajonként eltérő expressziós szintje állhat [Thomae et al. 2013]. A Hmr fehérje D. melanogasterben mutat magasabb expressziót, míg $D$. simulansban az Lhr fehérje szintje magasabb. A fehérjék egymáshoz viszonyított aránya hatással van a kromoszómákon történő lokalizációjukra. Akár az egyik, akár a másik fehérje expressziós szintje magasabb, az kedvez a HmrLhr komplex kialakulásának a centromeren. Azonban a hibridben, ahol mindkét fehérje szintje magas, a Hmr-Lhr komplex aspecifikusan előfordulhat több heterokromatikus régióban is, ami a mitotikus folyamatok zavarához és letalitáshoz vezet [összefoglalva: Fukugawa 2013].

Tehát, ezek a gyors evolúciójú fehérjék, melyek a kromoszóma integritásáért felelnek, potenciálisan, de nem szükségszerűen poszt-zigotikus korlátként működhetnek.

Habár a PRDM9 és a Hmr-Lhr fehérjék eltérő mechanizmussal múködnek közre a fajképzésben (PRDM9 esetében a fehérje sajátos szerkezete teszi lehetővé a felismerési szekvencia megváltozását [Oliver et al. 2009], míg a Hmr-Lhr fehérjék expressziós szintbeli különbsége miatt szenved zavart a centromer múködése Drosophila hibridben [Thomae et al. 2013, Fukagawa 2013]), rendelkeznek közös jellemzőkkel, mint a gyors evolúció és az egész kromoszómát érintő funkció. Ilyen, az egész kromoszómát érintő funkció a kromoszómák végén a telomer fenntartása is, melyet ecetmuslincában gyorsan változó fehérjék végeznek.

A Drosophila nemzetség, és általában a Dipterák fajgazdagsága igen nagy. Több mint 1500 Drosophila faj [Bächli, G. (1999-2008)] ismeretes, melyek közül közel 380 faj él a Hawaii szigeteken. Az adatok arra utalnak, hogy a Drosophilák törzsfejlődése során a környezeti korlátok mellett több belső mechanizmus is kialakulhatott a fajok gyors izolálására [Mallet 2006]. Ilyen a fajképzésben részt vevő gének lehetnek a gyorsan változó terminin fehérjék is. 


\subsection{Gyorsan evolválódó fehérjék és interakcióik}

A terminin fehérjék egyik legérdekesebb tulajdonsága, hogy gyors evolúciót mutatnak. Ez leginkább azért meglepő, mert a sejtben az alapvető szerepet betöltő gének általában konzerváltak.

Az élet alapját jelentő sejtműködési funkciókat biztosító gének hosszú evolúciós múlttal rendelkeznek. Mivel az ilyen alapvető szerepet betöltő fehérjék esetében evolúciós léptékben is elegendő idő állt rendelkezésre az optimális aminosav sorrend eléréséhez, valamint az expressziós és az interakciós mintázatok stabilitásának kialakulásához, ezért nagymértékben konzerválódtak és csak ritkán fordul elő bennük változás.

A gyors változás és a fontos funkció kockázatos kombinációnak túnik, amely veszélyeztetheti a sejt múködését. Ennek ellenére vannak fontos szerepet betöltő gyors evolúciójú fehérjék, amelyek mégis képesek stabil kölcsönhatások kialakítására. A látszólag ellentmondásos jelenség több mechanizmussal is magyarázható.

A legkézenfekvőbb magyarázat lehet, hogy a gyorsan evolválódó fehérjék is tartalmazhatnak konzervált doméneket. A konzervált domén pedig legtöbbször akkor is képes ellátni a feladatát, ha a molekula többi része megváltozott, így a gyors evolúció nem jelent kockázatot a sejt múködésére.

Egy másik magyarázatot a különböző formákban megjelenő redundancia kínálhat. Vannak olyan fehérjék is, amelyek funkciót ellátó doménjei is gyorsan változnak. A funkció megőrzéséhez ezekben valamilyen természetű redundanciát kell feltételeznünk. Például a PRDM9 gyorsan evolválódó doménje zinc-finger motívumok ismétlődéséből áll [Oliver et al. 2009]. Ebben az esetben egy-egy motívum változása vagy esetleg kiesése nem jelenti a DNS-hez való kötési képesség megszúnését, csupán a szekvencia felismerés specifikusságát érinti.

Másik példa az, ha egy gén duplikálódik. Ebben az esetben a génpár egyes tagjain a szelekciós nyomás kisebb, mint a duplikációs esemény előtt a génen, mert az egyik gén terméke még biztonsággal ellátja a funkcióját, amíg a másik gén termékében több aminosav is megváltozhat.

$A z$ is elképzelhető, hogy a redundancia a fehérje szerkezetéből adódik: az aminosav sorrend kevésbé fontos, mert a fehérje funkciót a térszerkezet biztosítja. Néhány, a múködéshez esszenciális aminosav megfelelő pozícionálása pedig többféle aminosav szekvencia segítségével is megoldható. Az oligoszacharid illetve DNS és RNS kötéséről ismert Ob-fold fehérjék családja például nagy szekvencia diverzitást mutat, mégis rendkívül hasonló a térszerkezetük [Guardino et al. 2009].

Elméletileg két gyors evolúciójú fehérje között megmaradó stabil interakciót okozhatja a fehérjék koevolúciója is, ahol az egyik fehérjében történő változást a másik fehérjében bekövetkező újabb 
változás kompenzál. A kölcsönhatásnak ebben az esetben is bizonyos rugalmassággal kell rendelkeznie, hogy a mutációkat elviselje. Viszont pár mutáció-kompenzáció ciklus után a két fehérje annyira különbözhet a kiindulási fehérjéktől, hogy azokkal már nem képesek kölcsönhatásba lépni.

A terminin fehérjék evolúciója felgyorsult, mégis interakcióba lépnek egymással, mely elméletben magyarázható a fehérjék közti koevolúcióval.

Egy hipotetikus Drosophila hibridben két fajból származó HP1, HOAP, HipHop, Ver és DTL fehérjék találhatóak. Az eltérő fajokból származó fehérjék között kialakuló kölcsönhatások alapján alapvetően három féle terminin komplex formálódhat. Elképzelhető, hogy a különböző fajokból származó fehérjék egyáltalán nem hatnak kölcsön egymással és mindegyikük létrehozza a saját fajra jellemző terminin komplexét. Ebben az esetben az kromoszóma végeken véletlenszerú eloszlásban jelennek meg a tisztán egyik, vagy másik fajból származó komplexek, melyek nem lépnek egymással interakcióba. A kölcsönhatásuk viszont feltehetően szükséges a telomerikus hurok vagy G-kvadruplex kialakulásához, ezért veszélyeztethetik a sejt életképességét. Ennek a lehetőségnek a valószínűsége igen alacsony, hiszen a HP1 fehérje konzervált, és habár az egyik, vagy másik fajból származó gyorsan evolválódó fehérjék, mint például a HOAP vagy a HipHop egymással nem is, de a konzervált HP1-gyel interakcióba léphetnek. A második lehetőség tehát, hogy a sejtekben hibrid komplex formálódás kezdődik, azonban mert a gyorsan evolválódó tagok között nem alakul ki kölcsönhatás, nem alakul ki mind az ötféle fehérjét tartalmazó működőképes komplex. A harmadik lehetőség, hogy mindegyik fehére kölcsönhat egymással és teljes hibrid komplexeket alakítanak ki. A komplex funkcióképessége ebben az esetben is kérdéses. A gyors evolúció miatt számos aminosav különbség okozhat akkora térbeli eltéréseket a komplex felszínén, melyek veszélyeztethetik a komplex helyes múködését.

Ha tehát két közeli rokon fajból származó egyazon komplex tagjait vizsgálva nem találunk kölcsönhatást a komplex fehérjéi között, akkor ezt a molekuláris elkülönülés kimutatásaként értékelhetjük. E logika szerint a gyors evolúcióval kialakuló eltérések a hibrid komplex létrejöttét gátolják és ezzel hibrid letalitást okoznak. Megjegyzendő, hogy a fordított eset, azaz eltérő fajok terminin fehérjéi közötti kölcsönhatás kimutatása ugyanakkor nem jelent cáfolatot a terminin fehérjék fajképzésben betöltött esetleges szerepére. A komplex fizikai képződése ugyanis nem jelenti feltétlenül funkcionális tulajdonságainak a megtartását, illetve azonosságát. A gyorsan változó fehérjék tanulmányozása azonban ebben az esetben is számos érdekes információval szolgálhat a fehérjék közti interakció természetéről. 


\section{Célkitűzések}

A Drosophila kromoszóma végek védelme és fenntartása, és az ebben szerepet játszó, gyorsan evolválódó, fehérjék vizsgálata számos érdekes probléma megközelítésére ad lehetőséget. A közvetlenül a terminin komplex szerkezetére és múködésére vonatkozó kérdéseken túl ilyenek az egymással fizikai kapcsolatban álló fehérjék esetleges koevolúciójára vonatkozó kérdések. A dolgozatom alapját képező munkában e kérdések közül többet vizsgáltam. A telomert védő terminin komplex szerveződését és az abban részt vevő fehérjék kapcsolatait tanulmányoztam, különös tekintettel e fehérjék Drosophila fajok közötti változékonyságára. Munkámmal részben arra a kérdésre kerestem a választ, hogy a telomert védő fehérjék gyors evolúciója hozzájárulhat-e új fajok kialakulásához.

I. In silico vizsgálatokat végeztem azzal a célkitúzéssel, hogy meghatározzam:

I/a: azonos sebességgel változnak-e az egyes terminin fehérjék részei, vagy vannak eltérő sebességgel evolválódó domének a fehérjéken belül (4.1 fejezet).

I/b: a rendelkezésre álló szerkezeti adatok alapján hogyan jósolható meg az, hogy egy adott terminin fehérje változásai milyen hatással vannak a térszerkezetre és a funkcióra $(4.2$ fejezet).

II. A terminin komplex szerveződésének és működésének vizsgálatához célul tűztem ki:

II/a: a komplexet alkotó fehérjék előállítását heterológ rendszerben, további biokémiai vizsgálatokra alkalmas formában (4.3 fejezet).

II/b: a komplex tagjai között kialakuló kapcsolatok vizsgálatát teljes vagy részkomplex(ek) létrejöttének in vitro kimutatásával (4.4 fejezet).

III. A terminin komplex speciációban játszott szerepére vonatkozó elképzelés megerősítésére célom volt annak vizsgálata, hogy kialakul-e terminin alkomplex eltérő fajokból származó alegységekből (4.5 fejezet).

IV. Célom volt, az egyes alegységek jellemzésével a Drosophila telomer védelmét biztosító terminin komplex és az emlős shelterin komplex működésének és sajátosságainak összehasonlítása (4.6 fejezet). 


\section{Anyagok és módszerek}

\subsection{Bioinformatika}

\subsubsection{Szekvencia illesztések}

A terminin gének kódoló szekvenciái, a Drosophila melanogaster esetén a Flybase adatbázisból (http://flybase.org/) származnak. Ezeket a szekvenciákat használtam fel a BLAST algoritmussal történő kereséshez 21 Drosophila faj (Drosophila ananassae, D. biarmipes, D. bipectinata, D. elegans, $D$. erecta, D. eugracilis, D. ficusphila, D. grimshawi, D. kikkawai, D. melanogaster, D. miranda, $D$. mojavensis, $D$. persimilis, $D$. pseudoobscura pseudoobscura, $D$. rhopaloa, $D$. sechellia, $D$. simulans, $D$. takahashii, D. virilis, D. willistoni, D. yakuba) teljes genom shotgun contig adatbázisából. A Drosophila melanogaster szekvenciákkal történő keresés a nagy változatosság miatt kevésnek bizonyult ahhoz, hogy a kódoló régiókat mind a 21 fajban azonosítsuk. Ezért az első keresésből kapott találatokat felhasználtuk újabb keresésekhez, melyek a hiányzó fajokkal mutatott nagyobb homológia miatt már lehetővé tette a gének azonosítását.

A HipHop és a HOAP fehérjék többször is duplikálódtak az evolúció során. Az ortológok és paralógok többségét Dubruille és munkatársai már azonosították [Dubruille et al. 2012], viszont négy általunk vizsgált fajjal nem foglalkoztak (D. miranda, $D$. yakuba, $D$. sechellia, D. erecta). A kimaradt fajokban is sikerült azonosítani HipHop és HOAP ortológokat. Továbbá azonosítottunk egy HOAP paralógot a $D$. miranda esetében, mely a többi kimaradt fajban nem volt jelen. Azért hogy eldöntsük, melyik találat jelenti HOAP ortológot és melyik a paralógot, megvizsgáltuk a gének genomi környezetét. Amennyiben a szomszédos gének azonosak voltak a paralógot nem tartalmazó fajokéval, a gént ortológnak tekintettük.

A BLAST találatok szekvenciái $5^{\prime}$ és $3^{\prime}$ irányba is 0,5-1 Mb-sal kiterjesztve kerültek letöltésre. A szekvenciákon a kódoló régiókat az Augustus program segítségével azonosítottuk [Stanke et al. 2004]. Feltehetően intronok hiánya és a kódoló szakasz rövidsége miatt, néhány esetben a Ver szekvenciákban az Augustus nem talált nyitott leolvasási keretet. Ezekben az esetekben a Ugene programot használtam a kódoló régió meghatározására, mely a rövid kódoló régiókat is felismeri [Okonechnikov 2012].

Az azonosított régiók pozícióját illetve a gének annotációs számát a függelékekben összegeztem (1. függelék). 
Ezt követően a Ugene program segítségével a nukleotid szekvenciákat lefordítottam aminosav szekvenciára és T-coffee algoritmussal alapértelmezett beállítások mellett (-50 rés nyitási büntetéssel) illesztettem egymáshoz [Notredame et al. 2000]. A Ugene kiszámolta, hogy az egyes aminosavak hány százalékban azonosak a konszenzus szekvenciával, mely érték az aminosavak konzerváltságával arányos.

\subsubsection{Globuláris-rendezetlen szerkezetek meghatározása}

A D. melanogaster fehérjék globuláris régióinak meghatározását a Globplot nevű szoftverrel végeztem, mely Russell és Linding definíciója alapján végezte a számításokat [Linding et al. 2003].

\subsubsection{Kodon-illesztések és az evolúció sebességének számítása}

A fehérjéket kódoló nukleinsavak klasszikus módszerekkel történő illesztése nem veszi figyelembe a leolvasási keretet, így az egyes kodonok ezzel a módszerrel nem vizsgálhatóak.

Ezért korábban T-coffee algoritmussal illesztett aminosav szekvenciákat használtam fel kodonillesztések készítéséhez a PAL2NAL program segítségével [Suyama et al. 2006]. A kodon-illesztések alkalmasak a kodonok összehasonlítására és a szinonim és nem szinonim szubsztitúciók SNAP programmal történő vizsgálatára [Korber 2000].

\subsubsection{Három dimenziós térszerkezeti modellek készítése}

A fehérje modelleket az UCSF Chimera programcsomaggal kezeltem [Pettersen et al. 2004]. A Ver fehérjét egy korábban publikált szekvencia illesztés alapján [Raffa et al. 2010] az Stn1 fehérje szerkezetéhez illesztettem a Chimera MODELLER kiterjesztésének segítségével [Webb és Sali 2014]. A MODELLER hátránya, hogy csak az illeszthető régiókra számít térszerkezetet. Phyre2 szerver használatával viszont az egész megadott szekvencia modellezése megtörténik, így nagyobb lefedettségű predikciót kaptam a Ver térszerkezete [Kelley et al. 2015]. A Phyre2 azonban a többi gyors evolúciójú terminin fehérje esetén nem adott felhasználható eredményt.

\subsubsection{Western blot kísérletek kiértékelése}

A western blotok kiértékelése és a jelek (bandek) erősségének összehasonlítása az ImageJ szoftvercsomag segítségével történt [Schneider et al. 2012].

\subsubsection{Magi lokalizációs szignál predikciója}

A magi lokalizációs szignál predikciója a cNLS Mapper segítségével történt $D$. melanogaster Ver aminosav szekvencián, 3.0 „cut-off” pontozást alkalmazva [Kosugi et al. 2009]. 


\subsection{Klónozás}

\subsubsection{Kódoló régiók, plazmidok}

A klónozáshoz használt cDNS-ek a Drosophila Genomics Resource Center-tôl (Indiana University, Bloomington) származnak. A Drosophila yakubából származó géneket Ökrösné Gercsó Katalin izolálta a Szegedi Biológiai Központban.

Az Escherichia coli bakteriális expresszióhoz a pET16a vagy pET22b plazmid (Novagen) vázat használtam, a baculovírushoz a pAcUW21 (BD Biosciences) plazmidot.

\subsubsection{Bakteriális tápoldatok és táptalajok}

Az Escherichia coli törzsek növesztéséhez LB tápközeget ( $1 \%$ tripton, 0,5\% élesztő kivonat, $1 \% \mathrm{NaCl}$ ) használtam. A szilárd táptalajok 1,5\% agart tartalmaztak. A pET és pAcUW21 vektorokat hordozó transzformánsokra $100 \mu \mathrm{g} / \mathrm{ml}$ ampicillin (Sigma-Aldrich) antibiotikummal szelektáltam. A Rosetta sejtek szelekciójához $34 \mu \mathrm{g} / \mathrm{ml}$ kloramfenikolt (Sigma-Aldrich), míg az Arctic Express sejtekhez 25 $\mu \mathrm{g} / \mathrm{ml}$ gentamicint (Lonza) használtam.

\subsubsection{Transzformálás}

A munkám során használt plazmidokat transzformálással juttattam a kompetens baktériumokba. A kompetens sejteket Inoue protokollja alapján készítettem el, majd $-80^{\circ} \mathrm{C}$-on tároltam felhasználásig [Inoue et al. 1990]. A transzformálások során $100 \mu \mathrm{l}$ kompetens sejthez $10 \mu \mathrm{l}$ ligátumot vagy 30-40 ng plazmid DNS-t mértem, és jégen inkubáltam 20 percig. Ezt követően 30 másodperc $42^{\circ} \mathrm{C}$-os hősokkot alkalmaztam. Ezt követően $1 \mathrm{ml}$ LB médiumot mértem hozzájuk, és 1 órán keresztül $37^{\circ} \mathrm{C}$-on inkubáltam őket. Végül a sejteket szelektív, a megfelelő antibiotikumot tartalmazó LB lemezre szélesztettem.

\subsubsection{Plazmidtisztítás a klónozási lépésekhez (Miniprep)}

A plazmidok tisztítására hagyományos alkalikus lízis technikát alkalmaztam.

A szelektív médiumban éjszakán át (8-16 óra) felnövesztett baktériumkultúrát Eppendorf csövekbe pipettáztam, majd $13000 \mathrm{rpm}$ fordulatszámmal centrifugáltam fél percen át. A felülúszót eltávolítottam. A sejteket ezt követően $100 \mu$ l BRS oldatban (50 mM glükóz, 50 mM Tris-HCl pH 8,0, 10 mM EDTA) szuszpendáltam, majd jégre helyeztem. A sejtek líziséhez $200 \mu$ l LS-t (200 mM NaOH, 1\% SDS) mértem az Eppendorf csövekbe, és forgatással óvatosan elegyítettem. A mintát jégen inkubáltam, amíg áttetszővé nem vált. A sejtek lízisét követően 150 l 3 M kálium-acetátot (az oldat acetátra nézve $5 \mathrm{M}$ ) pipettáztam a csövekbe; óvatosan elegyítettem, majd 10 percre jégre tettem, míg a fehérjék kicsapódtak. Ezt követően 10 percig 13000 rpm fordulatszámmal centrifugáltam a 
mintát. A plazmid DNS kicsapásához a felülúszót $1 \mathrm{ml}$ 96\%-os etanolt tartalmazó Eppendorf csövekbe mértem, megkevertem, és 5 percet hagytam állni jégen. A mintát ismét $13000 \mathrm{rpm}$-en centrifugáltam 5 percen át. A felülúszót eltávolítottam, és vártam három-négy percet, hogy a csapadék megszáradjon. A plazmid DNS-t ezt követően $50 \mu \mathrm{l} 20 \mu \mathrm{g} / \mathrm{ml}$ RNáz tartalmú TE (10 mM Tris-HCl, pH 8,0, 1 mM EDTA) pufferben oldottam fel.

\subsubsection{A DNS enzimatikus módosítása}

$P C R$

Alapvetően kétféle PCR reakciót alkalmaztam munkám során. A kódoló régiók pontos és megbízható sokszorosítását az erre a célra fejlesztett nagy pontosságú DNS polimerázzal, a Phusion polimerázzal (ThermoFisher Scientific) végeztem. A PCR során a pontos átírásnak kedvező „HF” jelzésű puffert használtam.

A plazmidok és inszertek összeépítését követően az előállított plazmidokat baktériumokba transzformáltam. Mivel az összeépítés során kapott és transzformált DNS elegy nem csak a várt szerkezetű plazmidokat tartalmazza, a felnőtt kolóniák is eltérő szerkezetű plazmidokat hordozhatnak. A számunkra megfelelő plazmidot hordozó kolóniák kiválasztását kolónia PCR-ral végeztem. Ebben az esetben egy pozitív-negatív választ keresünk, így a Phusion polimeráz helyett egy gazdaságosabb DreamTaq polimerázt (ThermoFisher Scientific) használtam.

Az alkalmazott protokollok a következők:

Nagy fidelitású PCR során $50 \mu$ t térfogatú reakciókat mértem össze az alábbi recept szerint:

- $0,5 \mu$ templát plazmid DNS

- $2-2 \mu l$ primer (10mM)

- $1 \mu \mathrm{l}$ dNTP mix (10mM)

- $\quad 10 \mu \mathrm{l}$ x HF pufferből

- $\quad 0,1 \mu \mathrm{l}$ Phusion DNS polimeráz

- $34,4 \mu \mathrm{l} \mathrm{H} \mathrm{H}_{2} \mathrm{O}$ 
A PCR program a következő:

$95^{\circ} \mathrm{C}$ elődenaturáció 5 perc

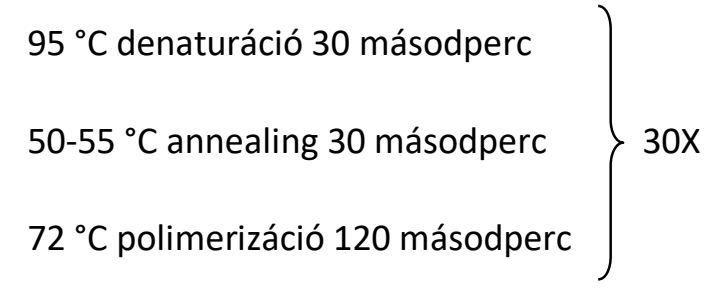

$72{ }^{\circ} \mathrm{C}$ polimerizáció 10 perc

Kolónia PCR során $20 \mu \mathrm{l}$ térfogatú reakciókat mértem össze az alábbi recept szerint:

- tip-hegynyi baktérium kultúra

- $\quad 1-1 \mu$ primer $(10 \mathrm{mM})$

- $0,5 \mu \mathrm{l}$ dNTP mix (10mM)

- $2 \mu \mathrm{l} 10 \mathrm{x}$ DreamTaq puffer

- $\quad 0,1 \mu \mathrm{l}$ DreamTaq DNS polimeráz

- $15,4 \mu \mathrm{l} \mathrm{H}_{2} \mathrm{O}$

A PCR program a következő:

$95^{\circ} \mathrm{C}$ elődenaturáció 10 perc

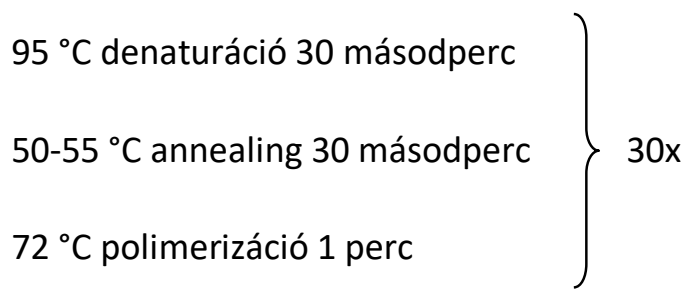

$72{ }^{\circ} \mathrm{C}$ polimerizáció 10 perc 


\section{Restrikciós endonukleázok}

A plazmid és inszert DNS-ek irányított összeépítését restrikciós endonukleázok használatával készítettem elő. A restrikciós enzimes emésztésekhez a ThermoFisher Scientific cég enzimeit, és a gyártó által javasolt puffereket és kondíciókat használtam.

\section{Foszfatázok}

A plazmidok és inszertek összeépítése során előfordulhat, hogy a plazmidok önmagukra zárulnak, és a későbbi transzformálásuk után jelentős mennyiségű telepet formálnak, melyek nem tartalmazzák a várt szerkezetű plazmidot. A fals pozitív telepek számának csökkentése lehetséges a plazmidok végeinek defoszforilálásával, mely magakadályozza azok önmagukra történő záródását. Linearizált plazmidok defoszforilálásához ThermoFisher Scientific gyártó által forgalmazott SAP (Shrimp Alkaline Phosphatase) enzimet alkalmaztam a gyártó javaslatainak megfelelően.

\section{A szabad DNS végek ligálása}

A megfelelő restrikciós enzimekkel kezelt plazmid és inszert DNS-ek összeépítéséhez, ligáláshoz a ThermoFisher Scientific cég T4 DNS ligázát, és a megfelelő puffert vettem igénybe. A beépítendő DNS fragmentumot a plazmidhoz képest legalább kétszeres feleslegben mértem a reakciókba. A reakcióelegyet $18^{\circ} \mathrm{C}$-on 3-4 órát vagy éjszakán (8-16 óra) át inkubáltam.

\subsubsection{Agaróz gélelektroforézis}

A klónozási lépések során fontos tudnunk, hogy a megfelelő DNS fragmentummal dolgozunk-e. Ezért a PCR reakciók során előállított DNS-t, a plazmid izolátumokat és minden egyéb DNS molekulát agaróz gél segítségével értékeltünk ki, mely lehetővé teszi a DNS koncentrációjának és a fragmentumok méretének a megbecsülését.

A munkám során $1 \%$ agaróz gélt használtam, mely gélek $0,5 \mu \mathrm{g} / \mathrm{ml}$ etídium-bromidot tartalmaztak. A futtatás 1x TAE pufferben (40 mM Tris- $\mathrm{HCl}$ pH 8,0, $20 \mathrm{mM}$ ecetsav, $1 \mathrm{mM}$ EDTA) történt $120 \mathrm{~V}$ feszültég mellett. A DNS fragmentumokat UV fénnyel megvilágítva tettük láthatóvá.

Fragmentum méret meghatározáshoz a ThermoFisher Scientific által forgalmazott molekulasúly létrát használtam („GeneRuler ${ }^{\mathrm{TM}} 1$ kb Plus DNA Ladder”, „GeneRuler ${ }^{\mathrm{TM}} 1$ kb DNA Ladder”).).

\subsubsection{DNS fragmentumok izolálása agaróz gélből}

Fragmentum izolálásra akkor van szükség, amikor a kiválasztott DNS fragmentumunk mellett más, nem kívánatos DNS fragmentumok is jelen vannak a mintában. Például az inszertek PCR-ral történő 
sokszorosítása során előfordulhat, hogy nem specifikus termékek is keletkeznek, melyektől ezzel a módszerrel szabadulunk meg.

A DNS fragmentumokat 1\%-os agaróz gélen elválasztottam, majd a kívánt fragmentumot tartalmazó géldarabkát kivágtam. Az agaróz darabból a DNS-t a Qiagen cég QIAquick Gel Extraction Kit segítségével nyertem ki, a gyártó által javasolt protokoll szerint.

\subsubsection{Alkoholos kicsapás}

Az egymást követő enzimreakciók között, amikor erre szükség volt, a DNS-t alkohollal csaptam ki. Ilyen esetekben a mintákhoz 2-2,5x mennyiségú abszolút etanolt adtam, forgatva megkevertem, majd 1 órára $-20^{\circ} \mathrm{C}$-ra helyeztem. Ezt követően 10 percet centrifugáltam a mintákat, a felülúszót eltávolítottam és 70\%-os etanolban mostam a csapadékot. 5 perc centrifugálás után leöntöttem a felülúszót, és hagytam a csapadékot beszáradni. A DNS-t desztillált vízben oldottam vissza.

3.2.9 Idegen fehérje expressziót monocisztronos elrendezésben biztosító plazmidok előállítása

A vektorként használt plazmidokat két restrikciós endonuklázzal hasítottam, amelyeket úgy választottam ki, hogy lehetővé váljon az inszert DNS irányított beépítése (mintánként változóan az alábbi enzimeket felhasználva: Ndel, Ncol, BgllI, Notl, BamHI). Az endonukleázokkal hasított plazmidok végeit a ligálási lépés előtt defoszforiláltam SAP enzimmel. Az inszerteket nagy fidelitású PCR-ral állítottam elő. A használt primerek segítségével restrikciós endonukleázok felismerési szekvenciáit alakítottam ki a kódoló régiók végein.

A felhasznált primerek a következők:

A színkódok a következő restrikciós endonukleázok felismerési helyeit jelölik: Ndel, Ncol, Notl, Bglll, BamHI, Xbal, Spel

HP1:5'GACACCATGGGCAAGAAAATCGACAACCCTGAGAGCTC3'(F),

5'GACAGGATCCTTAATCTTCATTATCAGAGTAC3'(R);

hisHP1: 5'GACACATATGGGCAAGAAAATCGACAACCCTGAGAGCTC3' (F)

HOAP: 5'GACACCATGGCACTGCTGCTACTATGTGTTAATATGTCGGGGAC3' (F),

5'GACAGGATCCTCAGGCTATTGAGGTGACGTC3'(R);

HipHop: 5'GACACATATGGCCTCCATTGACGAGGGCTCGCGCGTTGAGCGGAG3' (F), 5'GACAGGATCCCTAACCACCTGTGGTTCCCATC3' (R); 
HipHop-HA

5'AGATCTGCGGCCGCACTAGTCTAAGCATAATCTGGAACATCATATGGATAACCACCTGTGGTTCCCATCAAG TAAATATCC3' (R)

DTL/Moi: 5'GTACCATGGTTATGTCCCTGGTGCCAGAAGCCT3' (F), 5'GTAGGATCCTCATTTCTCGATCAGACTTCTCATCTCCA3' (R);

DTL/Moi-HA:

5’AGATCTGCGGCCGCACTAGTCTAAGCATAATCTGGAACATCATATGGATATTTCTCGATCAGACTTCTCATCT $\mathrm{CC}^{\prime}(\mathrm{R})$

DTL/Moi-HA (Baculovírusba): 5'GTAAGATCTATGTCCCTGGTGCCAGAAGCCTCTAC3' (F)

Ver: 5'GTACATATGGATTTTAATCAGAGTTTCGAGG3' (F),

5'CAAAGATCTCTATTTATTTGTTGTATTCTGCATTG3' (R)

Flag-Ver: 5'GGAATTCCATATGGACTACAAAGACGATGACGACAAGGATTTTAATCAGAGTTTCGAGGA3' (F)

Dyak-Ver:

5'CGATCTCTAGAAATAATTTTGTTTAACTTTAAGAAGGAGATATACATATGGATTGCAATCAGAGCTTCG3' (F), 5'GAAGATCTTCGCGGCCGCAACTAGTCTACTATTTCTCTGTCGAACTCTGTG3' (R);

A megfelelő enzimekkel hasítottam az inszerteket, hogy a linearizált plazmidokba ligálhatóak legyenek. Mind a plazmidokat, mind az inszerteket az egyes enzimatikus kezelések között alkoholos kicsapással tisztítottam. Az inszertek emésztését követően fragmentum izolálást végeztem, majd az inszerteket ligáltam a plazmidokba. A ligált DNS mintát DH5alfa sejtekbe transzformáltam és kolónia PCR segítségével azonosítottam a pozitív telepeket. A pozitív telepekből a korábban leírtak alapján kultúrát növesztettem és DNS-t preparáltam belőlük. A klónozás sikerességéről tesztemésztéssel és szekvenálással győződtem meg.

3.2.10 Idegen fehérje expressziót policisztronos elrendezésben biztosító plazmidok előállítása Heterológ fehérje termeltetés során baktériumban gyakori, hogy a fehérjék oldhatatlan formában termelődnek. Az oldhatóságot gyakran növeli, ha a fehérjék interakciós partnerei is jelen vannak a termeltetés során, ezért a fehérjék koexpressziójára alkalmas policisztonos vektorokat készítettem, melyek előállítása metodikailag nem különbözik a korábban leírtaktól. Az inszertek előállításához újabb PCR-t végeztem. Templátként a monocisztronos expressziós plazmidok szolgáltak, míg a 
kazetták előállításához szükséges primereket az üres pET plazmid szekvenciára terveztem, így eltérő kódoló régiók esetében is használható ugyanaz a primerpár:

5'CCCTCTAGAAATAATTTTGTTTAACTTTAAGAAGGAGATATA3' (F), 5'ATAGATCTGCGGCCGCACTAGTAACTCAGCTTCCTTTCGGGCTTTGTTAG3' (R).

A restrikciós endonukleázok felismerési helyei: Xbal, BgIII, Notl, Spel

A forward primer a pET expressziós vektorok riboszóma-kötő helyére hibridizál és egy Xbal hasítási helyet kódol. A reverse primer komplementer szekvenciája pedig a T7 transzkripció terminációs szignál előtt található. A reverse primer hordoz még Spel, Notl és Bglll felismerési helyeket is. Az ezzel a primerpárral készített PCR termék felépítése tehát a következő: Xbal-riboszóma kötő helycDNS-Spel-Notl-BgIII (4. ábra).

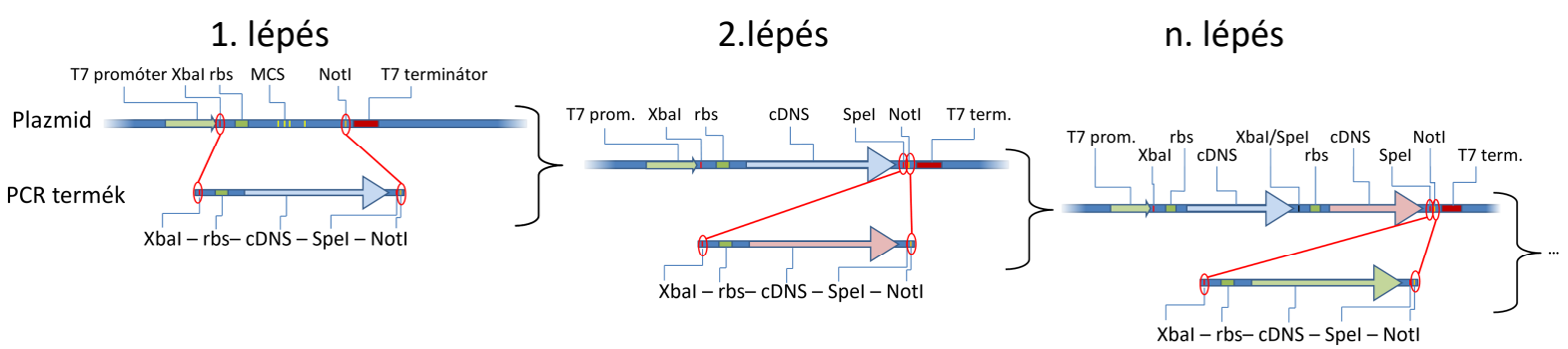

\section{4. ábra: A policisztronos expresszióhoz tervezett konstrukciók klónozási stratégiája}

Az első lépés során Xbal-Notl kezelt plazmidba (Plazmid) építjük a szintén Xbal-Notl kezelt inszertünket (PCR termék). Az így kapott plazmidot a második lépés során Spel és Notl enzimekkel emésztjük, míg a PCR termékünket továbbra is Xbal-Notl enzimekkel. Xbal és Spel kompatibilis véget adnak, ezért a két DNS molekula összeépíthető. Az így kapott plazmid már két kódoló régiót, egy-egy Spel-Notl helyet tartalmaz, mely lehetővé teszi további inszertek beépítését ( $n$. lépés).

A policisztronos konstrukció előállításához első lépésben a pET22 plazmidot és az inszertet is Xbal és Notl enzimekkel kezeltem, majd összeligáltam. Az így keletkezett monocisztronos plazmidot ezek után Spel és Notl enzimekkel kezeltem, míg a következő inszertet Xbal és Notl enzimekkel. A Spel és Xbal enzimek kompatibilis végeket adnak tehát az új cDNS beépül, viszont a ligálást követően mindkét enzim felismerési szekvenciája megszúnik. Tehát egy bicisztronos konstrukciót állítottunk elő), amely újfent csupán egy Spel felismerési helyet tartalmaz a Notl hely előtt. Ezzel a módszerrel tetszőleges számú inszert beépíthető az Spel-Notl helyekre.

\subsection{Virális vektor előállítása és fehérje termeltetés rovar sejtekben}

A haemagglutinin DTL fúziós fehérjét termelő baculovírust a Baculovirus Gold kit (BD Biosciences) protokollját követve állítottam elő. 
A DTL-t tartalmazó plazmidot és a vírust kotranszfektáltam Sf9 sejtekbe, ahol a transzgén a vírusba rekombinált. A rekombináns vírusokat hígításos módszerrel szelektáltuk, és a legnagyobb expressziót mutató törzzsel dolgoztunk tovább. A vírus sokszorosítását követően T-175 méretű flaskákban növesztett Sf9 sejteket fertőztünk. A fertőzést követően 3 nappal a sejteket gyújtöttük és $-80^{\circ} \mathrm{C}$-on tároltuk további felhasználásig.

\subsection{Bakteriális fehérje termeltetés}

A fehérje termelés BL21(DE3), Arctic Express vagy Rosetta sejtekben történt (Agilent Technologies, Inc.) $18{ }^{\circ} \mathrm{C}$-on (Arctic Express) vagy 30-37 ${ }^{\circ} \mathrm{C}$-on (BL21, Rosetta) 0,3-0,75 mM IPTG-t használva indukálószerként. A fehérjetermeltetés ideje a fehérjétől és sejttől függően 4-60 órás volt.

\subsection{Sejtek feltárása és a fehérjék oldhatóságának vizsgálata}

A sejtek feltárását ultrahangos kezeléssel (Sonics Vibra cell ${ }^{\mathrm{TM}}$ ) végeztem, hat cikluson keresztül, melyekben 20 másodperces aktív kezelést 10 másodperc szünet követett, 30\% amplitúdón. A felhasznált puffer összetétele $20 \mathrm{mM}$ Tris- $\mathrm{HCl}\left(\mathrm{pH}\right.$ 7,5), $100 \mathrm{mM} \mathrm{NaCl}$ és 1-1 mM MgCl${ }_{2}$ és $\mathrm{CaCl}_{2}$ volt.

Az ultrahangos sejtfeltárást követően a mintákat centrifugáltam. A csapadékot és a felülúszót is poliakrilamid gélen elemeztem. A csapadék és a felülúszó fehérje tartalmának összehasonlításával az idegen fehérje oldhatóságára következtettem.

\subsection{Tricin-SDS-PAGE}

A Ver és DTL fehérjék mérete (24 és 21 kDa) a klasszikus Laemli SDS-PAGE felbontásának alsó határán van. Ezért ezeket a fehérjéket tricin gélen választottam el $1 \mathrm{M}$ Tris, 0,33 $\mathrm{M} \mathrm{HCl}, 0,1 \%$ SDS pH 8,45 összetételü gél puffert, 0,1 M Tris- $\mathrm{HCl}$ pH 8,9 anód puffert, és $0,1 \mathrm{M}$ Tris, 0,1 M tricin, 0,1\% SDS, pH 8,25 katód puffert használva [Schägger 1987]. A tricin gélt az első fél órában 30-50V feszültséget alkalmazva futtattam, állandó $40 \mathrm{~mA}$ áramerősség mellett, majd másfél óráig 120-150 V-on $130 \mathrm{~mA}$ áramerősség mellett. A gélt $10 \%$ ecetsav és $50 \%$ metanol tartalmú oldatban fixáltam, majd Coomassie Brilliant Blue-val festettem és 10\% ecetsavban differenciáltam.

\subsection{Western blot}

A poliakrilamid gélelektroforézist követően a fehérjéket nitrocellulóz membránra transzferáltam 25 mM Tris, 192 mM glicin, 0,1\% SDS, 20\% metanol összetételű puffert használva, 40 V-on 90 percig. A membránt $5 \%$ tejpor tartalmú pufferben ( $5 \%$ sovány tejpor, $20 \mathrm{mM}$ Tris pH7,5, $150 \mathrm{mM} \mathrm{NaCl}$ ) kezeltem, hogy elkerüljem az ellenanyag nem specifikus kötődését a membránhoz. A haemagglutininnel jelölt fehérjéket nyúlból származó anti-HA elsődleges ellenanyaggal (Abcam ab9110) mutattam ki, míg a Flag-jelölt fehérjéket egér M2 ellenanyaggal (Sigma F3165). 
Tormaperoxidázzal konjugált, nyúl vagy egér antitest ellen termelt ellenanyagot használtam másodlagos ellenanyagként (Dako P0448, P0260). A különböző ellenanyagokkal 1 órán keresztül inkubáltam a membránt és a kezeléseket követően háromszor tíz percet mostam TBST-ben ( 20 mM Tris pH 7,5, $150 \mathrm{mM} \mathrm{NaCl,} \mathrm{0,05 \%} \mathrm{Tween).} \mathrm{A} \mathrm{jeleket} \mathrm{Immobilon} \mathrm{HRP} \mathrm{szubsztrát} \mathrm{adását} \mathrm{követően}$ (Merck) Li-Cor Western Blot szkenner segítségével detektáltam.

\subsection{Heparin kromatográfia}

A DNS-kötő fehérjék tisztításához gyakran használt eljárás a heparin oszlop kromatográfia, hiszen a heparin fizikai jellegeit tekintve hasonlít a DNS cukor-foszfát gerincére. A terminin fehérjék szekvenciától függetlenül képesek kötni a DNS-t, ezért ezzel a technikával kezdtem a tisztítási lépéseket.

Kromatográfia előtt a feltárt sejteket centrifugáltam és G75 Sephadex gyöngyökön (GE Healthcare) átszűrtem. A szürletet heparin-sepharose (GE Healthcare) oszlopra vittem $1 \mathrm{ml} /$ perc folyási sebességet alkalmazva. Pufferként $20 \mathrm{mM}$ Tris pH7,5, $100 \mathrm{mM} \mathrm{NaCl}, 5 \%$ glicerol oldatot használtam. Az oszlopra kötött fehérjéket 18-20 oszlop térfogatnyi $(1 \mathrm{ml})$ emelkedő $(0,1-1 \mathrm{M}) \mathrm{NaCl}$ gradienssel eluáltam Tris pufferben (20 mM Tris pH 7,5, $1 \mathrm{M} \mathrm{NaCl}, 5 \%$ glicerol) miközben $1 \mathrm{ml}$ térfogatú frakciókat gyújtöttem.

\subsection{Gélszürés}

A gélszűrés vagy méretkizárásos kromatográfia a natív fehérjék méret és alak szerinti elválasztását teszi lehetővé, ezért ideális technika fehérjekomplexek vizsgálatához.

A gélszürést Superdex 200 10/300 GL oszlopokon végeztem (GE Healthcare). A heparin-sepharose oszlopról származó mintákat ultrafiltrálással (Amicon, Merck) sómentesítettem és koncentráltam. A gélszűrés során $0,25 \mathrm{ml} /$ perc folyási sebesség mellett $0,3 \mathrm{ml}$ térfogatú frakciókat gyűjtöttem. A folyamat során $20 \mathrm{mM}$ Tris pH 7,5, $100 \mathrm{mM} \mathrm{NaCl}$ 5\% glicerin tartalmú puffert használtam. Az oszlopot Broad range SDS-PAGE Standard (Biorad) segítségével kalibráltuk. A 116, 66, 45 kDa méretű fehérjék elúciós csúcsát megjelöltük az ábrákon.

\subsection{Peptid mass fingerprinting - tömegspektroszkópia}

A tricin gélen elválasztott fehérjék festése Coomassie Brilliant Blue festékkel történt. A minket érdeklő fehérjéket jelző sávokat kivágtuk a gélből, majd redukciót és alkilációt követően tripszinnel emésztettük Sun és munkatársai leírása alapján [Sun et al. 2006]. A tripszin múködését 10\%-os hangyasavval állítottuk meg. A gélből a peptideket ultrahangos kezeléssel gyorsított diffúzióval távolítottuk el, és C18 töltettel sómentesítettük. A mintákhoz ezt követően 1:1 arányban dihidroxi- 
benzoesavat adtunk mátrixként, és a MALDI lemezre mértük, majd szobahőmérsékleten hagytuk beszáradni. A MALDI-ToF gép kalibrációja után a mintákat analizáltuk az „RP_2-3kDa-med” előre beállított paramétereit használva. A FlexAnalysis program segítségével vettük fel a spektrumot és azonosítottuk a mono-izotópos csúcsokat. A fehérjéket MASCOT és Prospector keresésekkel azonosítottuk a SwissProt.2014.3.7 adatbázisban.

\subsection{Immunaffinitás kromatográfia}

Haemagglutinin peptiddel jelölt DTL fehérje vagy Flag peptiddel jelölt Ver fehérje további tisztítása illetve kölcsönható partnerekkel történő együtt tisztítása érdekében immunaffinitás kromatográfiát végeztem. Haemagglutinin vagy Flag epitópok elleni ellenanyagot hordozó agaróz gyöngyökből (antiHA agaróz (Pierce), M2 anti-Flag agaróz (Sigma-Aldrich)) oszlopot készítettem. A DTL esetében a heparin-sepharose oszloppal tisztított frakciókat, míg a Ver esetében a sejtkivonatot 3-5 alkalommal újra töltöttem az oszlopra, hogy az telítődjön a heterológ fehérjékkel. A gyöngyökhöz kötött fehérjéket HA vagy Flag (Sigma) peptiddel eluáltam és tricin gélen azonosítottam.

\subsection{Far-western blot}

A far-western kísérlet egy módosított western blot, amely alkalmas fehérje-fehérje kölcsönhatás kimutatására. A „próba” fehérje potenciális kölcsönható partnereit nitrocellulóz membránra transzferáltam poliakrilamid gélelektroforézist követően. A membránt a nem specifikus kölcsönhatások elkerülése érdekében kötőpufferben (5\% tejpor $20 \mathrm{mM}$ Tris pH 7,5 $100 \mathrm{mM} \mathrm{NaCl}, 1$ $\mathrm{mM} \mathrm{MgCl} 2,1 \mathrm{mM} \mathrm{CaCl}$ ) inkubáltam. A próba előállításához a vizsgált fehérjét tartalmazó sejteket feltártam ultrahangos kezeléssel, majd centrifugáltam a mintákat. A felülúszót tízszeresére hígítottam kötőpufferben majd a membránokra mértem. A membránokat éjszakán át rázattam $4{ }^{\circ} \mathrm{C}$ on, majd TBST-vel mostam őket. A próba fehérje haemagglutinin epitópot hordoz, így jelenléte a membránon a western blot pontban leírtak alapján kimutatható.

A kísérlet során felhasznált rekombináns humán hisztonokat a New England Biolabs forgalmazza ( $\mathrm{H} 1$ : M2501S, H2A: M2502S, H2B: M2505S, H3.3: M2507S, H4: M2504S).

\subsection{DNS-kötés vizsgálata mágneses gyöngyökkel}

A DNS kötés vizsgálatához 80-mer oligonukleotidot terveztem, melynek egyik vége biotinilált és nem alakít ki másodlagos struktúrát (5. ábra). A kettős-szálú és 3' túlnyúló végú DNS előállításához a biotinilált DNS szakasznak a 80-mer és 40-mer hosszú komplementerét használtam. Egy telomerikus szekvenciából (HeT-A) ugyancsak 80-mer hosszú régiót és annak 80- és 40-mer komplementer szakaszait is felhasználtam a DNS kötés vizsgálatához. 
egyes-szálú DNS (ssDNS): 5’biotin-

TCCACCCATTTACCCGAGAGACACACATTTTACCCCATTTCCCCCTTTACACAGAGAGATTATTTAGCCGTTTCCC CTTA3'

kettős-szálú DNS (dsDNS) előállításához (komplementer):

5'TAAGGGGAAACGGCTAAATAATCTCTCTGTGTAAAGGGGGAAATGGGGTAAAATGTGTGTCTCTCGGGTAA ATGGGTGGA3'

3’ túlnyúló végű DNS előállításához (komplementer):

5'AAATGGGGTAAAATGTGTGTCTCTCGGGTAAATGGGTGGA3'

ssDNS (HeT-A): 5'biotin-

AGGACGGCAGTCATGACAAAATACTCTCACTCAAACAAATCGGTGGGCAAAGGGTGGACATTGAAAGGAAAA

ACAGGACA3'

dsDNS (HeT-A komplementer):

5'TGTCCTGTTTTTCCTTTCAATGTCCACCCTTTGCCCACCGATTTGTTTGAGTGAGAGTATTTTGTCATGACTGCC

GTCCT3'

3’ túlnyúló DNS (HeT-A komplementer):

5'ATTTGTTTGAGTGAGAGTATTTTGTCATGACTGCCGTCCT3'

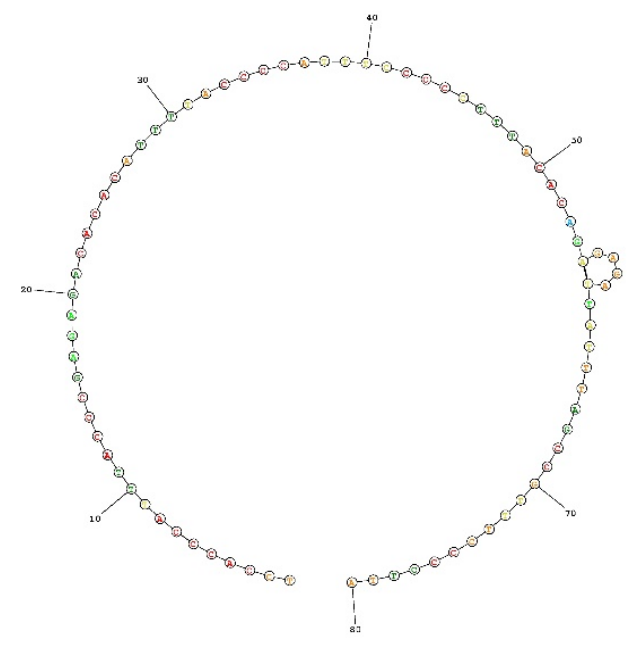

5. ábra: A tervezett egyes-szálú DNS-re az „RNA structure” szoftver predikciója alapján nem jellemző másodlagos szerkezet felvétele [Reuter JS és Mathews DH. 2010]

33. 
A biotinilált DNS-t mágneses gyöngyök felszínén rögzített streptavidinhez kötöttem (Dynabeads M280 Streptavidin a gyártó által javasolt protokollnak megfelelően). A heparin-sepharose oszlopról származó frakciókat a gyöngyökkel forgatva egy éjszakán át inkubáltam $4{ }^{\circ} \mathrm{C}$-on, majd háromszor mostam $20 \mathrm{mM}$ Tris pH 7,5 $100 \mathrm{mM} \mathrm{NaCl}, 1 \mathrm{mM} \mathrm{MgCl}, 1 \mathrm{mM} \mathrm{CaCl}$-ben. A fehérjéket $20 \mathrm{mM}$ Tris pH 7,5, $1 \mathrm{M} \mathrm{NaCl}$ tartalmú pufferrel eluáltam és western blot segítségével azonosítottam.

\subsection{DNS kötés vizsgálata bioréteg interferencia (BLI) segítségével}

Bioréteg interferencia mérések biomolekulák között kialakuló kölcsönhatások kimutatására alkalmas módszer. A mérésekhez olyan szenzorokat használunk, melyek belseje vezeti a fényt. A szenzort megvilágítva a fotonok a szenzor belsejében terjedve, annak végéről visszaverődnek és szintén a szenzoron belül visszajutnak a detektorba. Amennyiben a szenzor hosszát megváltoztatjuk a visszavert fényhullámok fázisa eltolódik, ami a detektorban interferenciát okoz, mely mérhető. A technikával a szenzor hossz változása pontosan megállapítható, mert arányos a detektorban mért interferencia mértékével. A szenzorok végére kötött biomolekulák a szenzor hosszának változását és ezzel a fényhullámok fázisának eltolódását eredményezik (6. ábra). A mérésekhez a FortéBio Octet rendszerét alkalmaztuk.

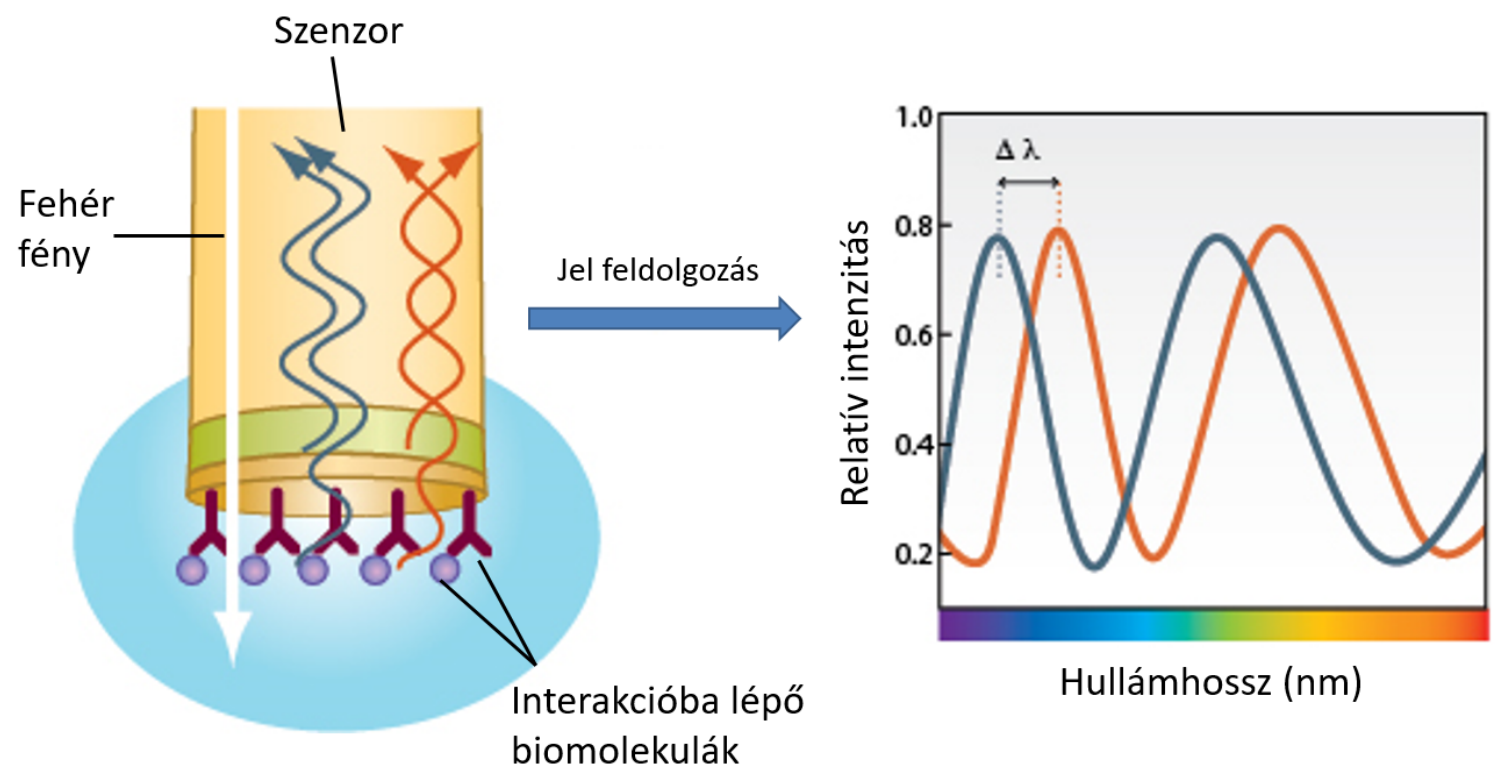

\section{6. ábra: Bioréteg interferencia múködési elve}

A szenzor belsejében terjedő fény egy része a szenzor végét elérve visszaverődik és a szenzoron belül haladva visszajut a detektorba. Amennyiben a szenzor hossza megváltozik, a fotonok eltérő fázisban verődnek vissza a szenzor végéről, mint korábban. A fáziseltolódás mértéke arányos a szenzor hossz változásával. (Az ábra FortéBio képeinek módosításával készült http://www.fortebio.com) 
A mágneses gyöngyökkel végzett kísérletekhez hasonlóan, egyes-szálú, kettős-szálú és 3’ túlnyúló végú DNS-t használtunk, melyeket biotin-sztreptavidin kölcsönhatást kihasználva a szenzorokhoz kötöttünk.

A reakciók során pufferként PBS puffert használtunk $\left(137 \mathrm{mM} \mathrm{NaCl}, 2,7 \mathrm{mM} \mathrm{KCl}, 10 \mathrm{mM} \mathrm{Na} 2 \mathrm{HPO}_{4}\right.$, 1,8 $\mathrm{mM} \mathrm{KH}_{2} \mathrm{PO}_{4}$ ) melyet 0,05\% Tween 20 detergenssel egészítettünk ki.

A mérésekhez először a különböző szerkezetű (egyes-szálú, kettős-szálú, 3’ túlnyúló végú) biotinilált DNS mintákat ( $3 \mathrm{ug} / \mathrm{ml}$ ) kötöttük a sztreptavidinnel telített szenzorokhoz (SAX szenzor, Fortébio). Ezt követően a szabad sztreptavidin molekulákat biotin konjugált lizinnel (10 ug/ml biocitin, Sigma) kezeltük, a nem specifikus kölcsönhatások elkerülése érdekében. A DNS-fehérje kötés mérése előtt mintapufferben vettük fel az alapvonalat, mely a mérések későbbi összehasonlításához szükséges. A kísérletek során a fehérjéink DNS kötése mellett a disszociációjukat is vizsgáltuk.

A rendszer alkalmas kinetikai mérések elvégzésére is. Az adatok kiértékelése az Octet szoftverével valósult meg a heterogén szubsztrát viselkedését leíró képlet alapján. A számításokhoz szükséges fehérjekoncentrációt poliakrilamid gélen futtatott minták számítógépes kiértékelésével becsültem. 


\section{Eredmények}

\subsection{A terminin fehérjék doménjei evolúciós léptékben gyorsan változnak}

A terminin fehérjék gyors evolúcióját többen leírták [Raffa et al. 2010, Gao et al. 2010, Dubruille et al. 2012], ám ezek az adatok általában egész fehérjékre vonatkoznak, és nem ismerjük meg belőlük az egyes domének változásának sebességét. Azonban, ha a terminin fehérjék fajképzésben betöltött szerepét vizsgáljuk, érdemes megnézni az evolúciós sebességet az interakciós doménekre is különkülön. Amennyiben ezek gyors evolúciót mutatnak és koevolúciójukat is sikerül alátámasztani, az az elméletünk megerősítését jelentheti.

A terminin fehérjék többségének doménszerkezete ismert, ami megkönnyíti a molekularészek evolúciójának a vizsgálatát. A fehérjék doménszerkezetét a 7. ábra foglalja össze (7. ábra).

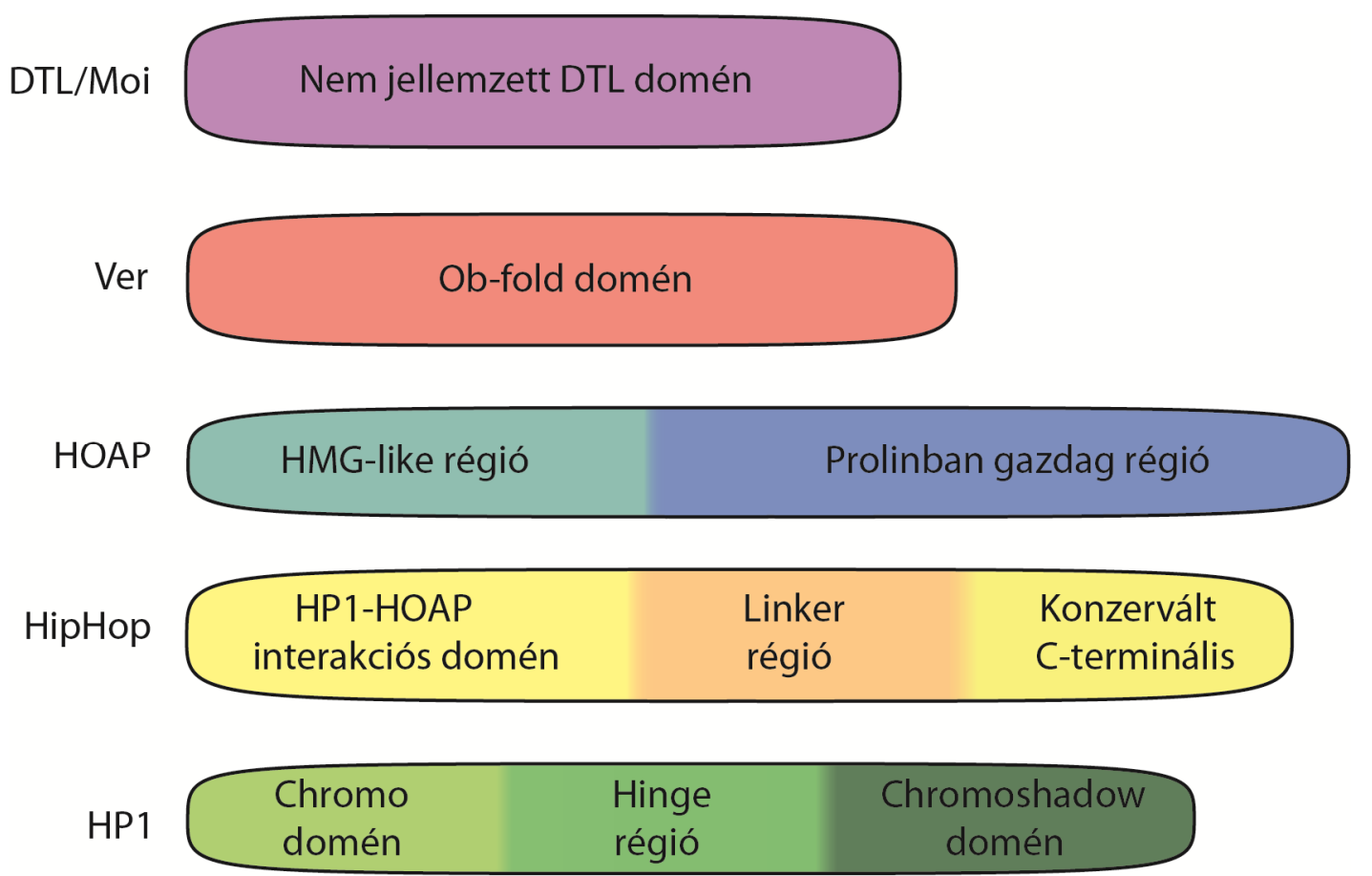

\section{7. ábra: A terminin fehérjék doménszerkezetének vázlatos ábrázolása}

A DTL domén szerkezete és pontos funkciója a terminin komplexen belül nem jellemzett. Kisméretű fehérje, ezért feltételezzük, hogy csupán egy domént hordoz. A Verrocchio szintén kisméretű fehérje, azonban homológiát mutat az élesztő shelterin egy tagjával, az Stn1 fehérjével. A Ver egyetlen domént, egy Ob-fold domént tartalmaz. Az Ob-fold doménnel rendelkező fehérjék az oligoszacharidokhoz való affinitásuk alapján kapták a nevüket (Oligosacharid-binding fold), azonban a szénhidrátok mellett a csoport számos tagja felismeri a DNS cukor-foszfát gerincét. A Ver molekuláris funkciója feltehetően az egyes-szálú DNS kötése [Raffa et al. 2010]. A HOAP fehérje két régióra osztható, az N-terminálisán található „HMG-like” doménre és a C-terminális 
három prolin tartalmú ismétlődésre [Badugu et al. 2003; Shareef et al. 2001]. A HMG-like régió felelős a kettősszálú DNS kötéséért [Shareef et al. 2001, Gao et al. 2010]. A C-terminálisnak a HP1-gyel való kölcsönhatásban van szerepe [Badugu et al. 2003]. HipHop 99 aminosavnyi N-terminális része felel HOAP-pal és HP1-gyel való kölcsönhatásáért. HipHop két további doménnel rendelkezik, a C-terminálison egy konzervált régióval, illetve egy összekötő (linker) régióval, ami összeköti a konzervált részt az interakciós doménnel. A konzervált régió felel HipHop heterokromatinban való lokalizációjáért [Gao et al. 2011]. HP1 három domént tartalmaz; a chromodomént, a chromoshadow domént és a kettőt összekötő „kapocs” vagy hinge régiót. A chromodomén a H3 hiszton metilált lizinjét ismeri fel és köti (H3K9me) [Bannister et al. 2001], ez a funkció azonban nem szükséges a telomeren való lokalizációhoz [Fanti et al. 1998]. A chromoshadow domén fehérje-fehérje kölcsönhatásért felelős domén, mely HP1 vagy más chromoshadow domént hordozó fehérjékkel való kölcsönhatást tesz lehetővé [Aasland, és Stewart 1995, Smothers és Henikoff 2000]. Badugu és munkatársai szerint HP1 chromoshadow és hinge régiója is szükséges a HOAP-pal való kölcsönhatásához. HOAP két HP1 molekulát köt úgy, hogy C-terminálisa kölcsönhatásba lép a hinge és a chromoshadow doménnel [Badugu et al. 2003]. A hinge domén köti az egyes-szálú (ezt nagyobb affinitással) és a kettős-szálú DNS-t [Perrini et al. 2004] és szintén szerepe lehet a H3K9me felismerésében [Mishima et al 2012].

A domének evolúciós rátájának összehasonlításához 21 Drosophila fajból összegyújtöttem a terminin fehérjékkel homológiát mutató szekvenciákat (ortológokat és paralógokat) és azokat bioinformatikai módszerekkel elemeztem. Referenciaként a konzervált Globin1 fehérjét és a gyorsan evolválódó Lhr fehérjét is bevontam a vizsgálatokba.

A kódoló régiókat aminosav szekvenciára fordítottam és szekvencia illesztéseket végeztem. Az illesztések alapján grafikusan ábrázoltam az egyes aminosavak konzerváltsági értékét (8. ábra). Az így készített ábrákon, az egyes domének határai tisztán elkülöníthetőek (8. ábra nyílhegyek). 
Globin1

Lhr

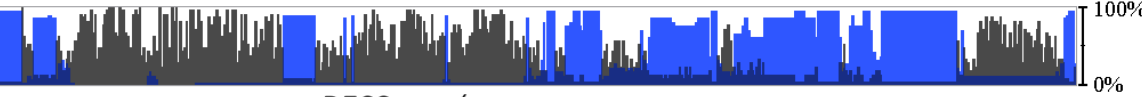 BESS motívum}

HP1

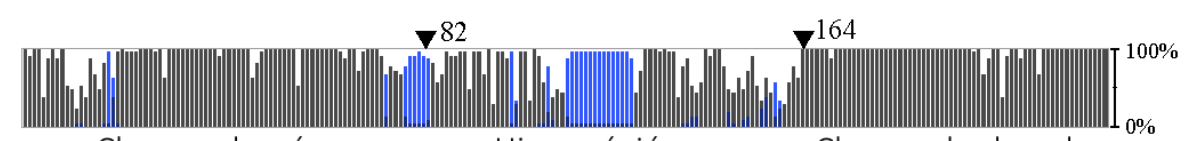

Chromo domén

Hinge régió

Chromoshadow d.

HOAP

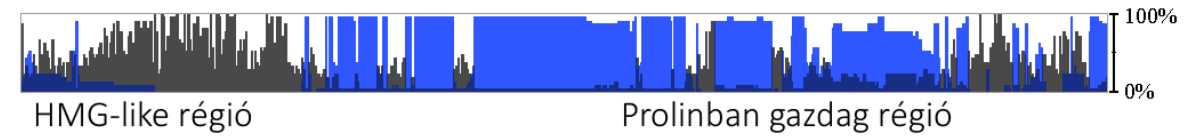

HOAPparalógok

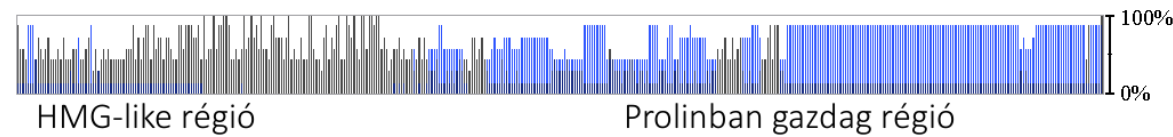

HOAP és paralógjai

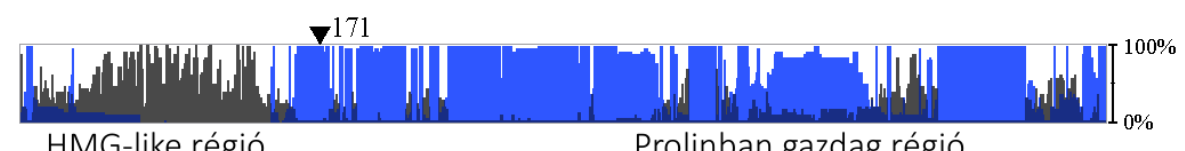

HipHop

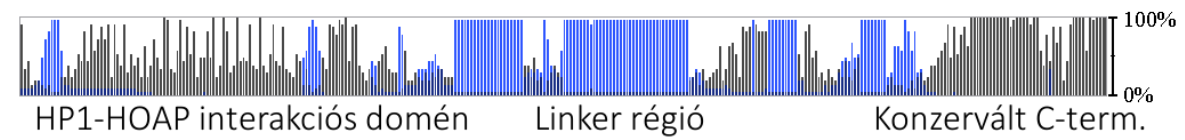

HipHopparalógok

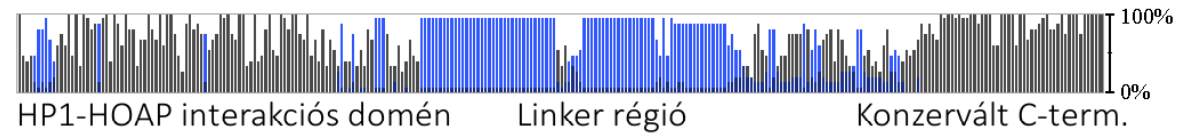

HipHop és paralógjai

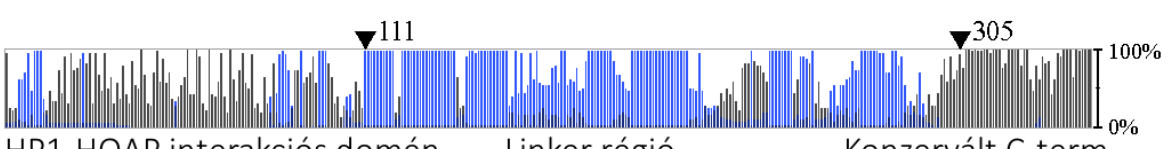

HP1-HOAP interakciós domén

Linker régió

Konzervált C-term.

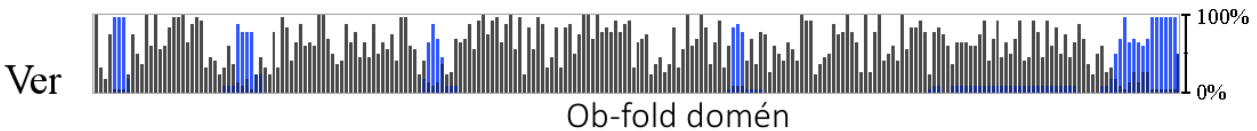

DTL/Moi

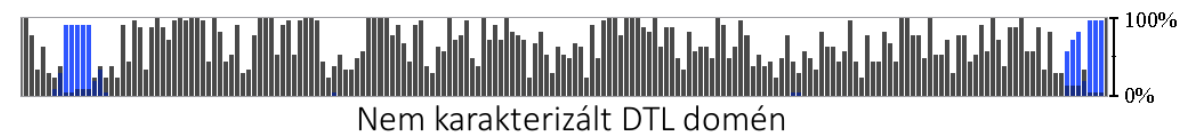

A konszenzus aminosav gyakorisága az illesztett szekvenciákon belül Az illesztésben található úrök (gaps) gyakorisága a szekvenciák között

8. ábra: A fehérje illesztések segítségével számolt konzerváltság alapján a fehérjék doménjei elkülöníthetőek. A szürke oszlopok a szekvencia illesztések alapján meghatározott konszenzus aminosav gyakoriságát jelzik a vizsgált szekvenciák között. Minden oszlop egy-egy aminosavnak felel meg, minél magasabb egy oszlop annál 
konzerváltabb az adott aminosav. Az Lhr és HOAP szekvenciái túl hosszúak, hogy az egyedi aminosav eloszlás megfelelő felbontással ábrázolható legyen, ezért oszlopok helyett folytonos színezést látunk. A kék oszlopok az illesztésben található lyukakat (inszerciók/deléciók) mutatják szintén aminosav szintű felbontásban a szekvenciákban előforduló gyakoriságuk szerint. Az alacsony szürke és magas kék oszlopok egy-egy inszerciót jelölnek. Az alacsony kék oszlopok átfedésben magasabb szürke oszlopokkal deléciókat jelölnek. A HOAP és a HipHop esetén ábrázoltuk az ortológokra, a paralógokra és az összes homológ szekvenciára jellemző adatot is. HP1, HOAP és paralógjai illetve HipHop és paralógjai esetén nyílhegy jelöli a domének határait.

A HOAP prolinban gazdag régiója és a HipHop linker doménje jelentős mennyiségű inszerciót hordoz a globuláris doménekhez viszonyítva, csakúgy, mint a gyorsan evolválódó Lhr több szakasza. A HP1 kapocs (Hinge) régiójában szintén láthatunk inszerciókat. A kisebb fehérjékre (Globin1, Ver, DTL), melyek feltehetően egy domént hordoznak, nem jellemzőek az ilyen változások.

A Drosophila melanogasterből származó fehérjék szekvenciájában megvizsgáltuk, hogy mekkora valószínúség szerint alkotnak globuláris vagy rendezetlen struktúrákat. Nem meglepő, hogy egyes rendezetlen struktúrájú fehérjerészekre (HOAP prolinban gazdag C-terminálisa, HipHop linker szakasza, HP1 hinge régiója) jellemzőbb az inszerciók jelenléte (9. ábra, 2-6. függelékek). A HipHop és a HOAP esetén a globulárisnak jelzett régiók egybeesnek a domének határaival. A nem strukturált domének funkciója a komplex összeszerelésében jelentős lehet [Dyson és Wright 2005], viszont kölcsönható partner nélkül az ilyen molekularészek akár in vivo is gyorsan degradálódnak [Janin és Sternberg 2013]. 


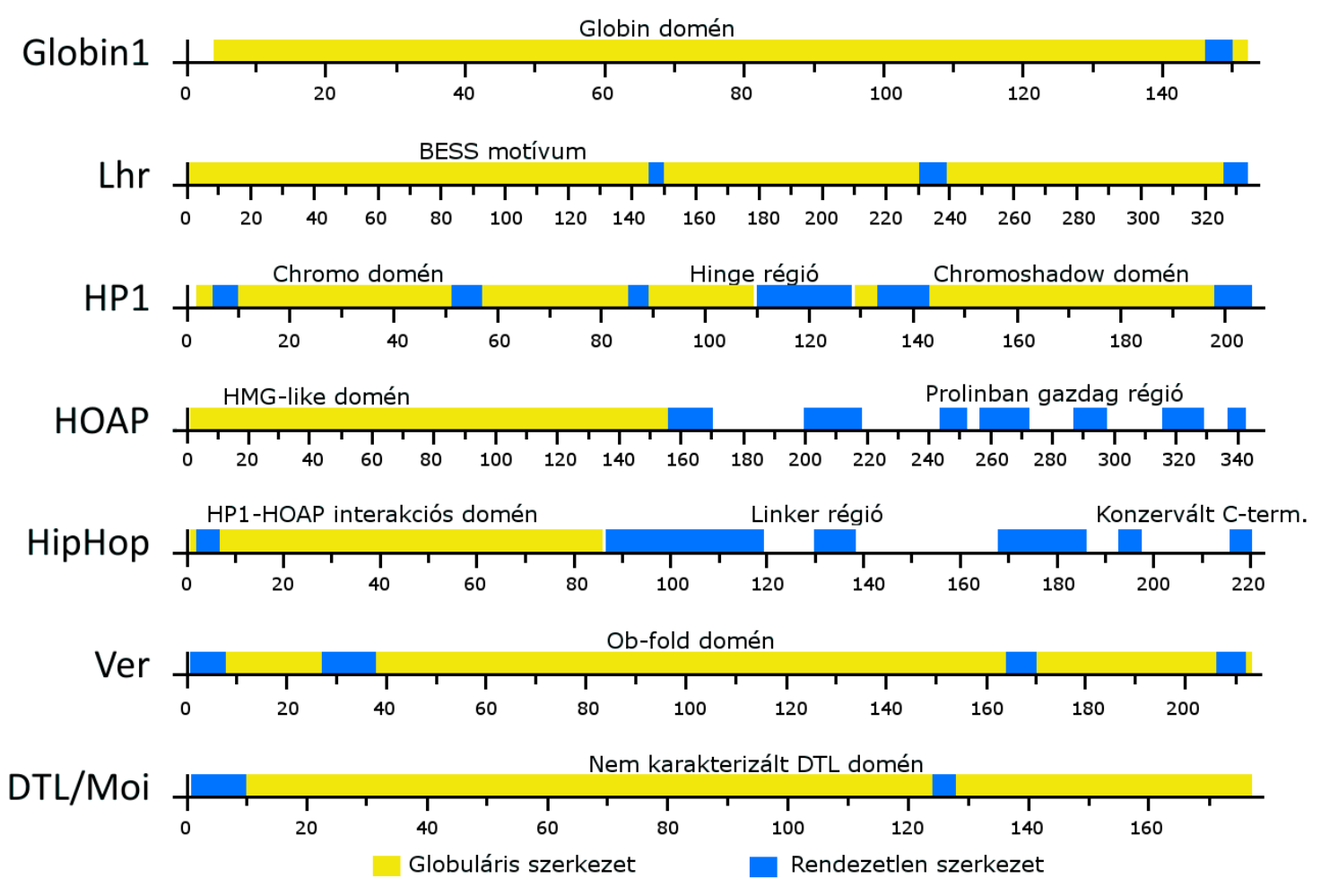

9. ábra: A vizsgált fehérjék közül Globin1, Lhr, Hp1, Ver, és DTL globuláris szerkezetet mutat, míg HOAP és HipHop C-terminálisuk felöl kiterjedt rendezetlen struktúrával rendelkeznek.

Russell és Linding definíciója szerint végzett predikciók [Linding et al. 2003]. A sárga szakaszok a globulárisnak prediktált régiókat jelzik, míg a kék részek a rendezetlen szakaszokat. A számítások a D. melanogaster szekvenciái alapján történtek. A tengelyen látható számok az aminosavak sorszámának feleltethetőek meg.

Az elkészült aminosav illesztésekből kodon illesztéseket készítettünk. A kodon illesztések olyan nukleinsav illesztések melyekben a kodonok pozíciója megfelel az általuk kódolt aminosav pozíciójának az aminosav illesztésben. A kodonok összehasonlításával, azaz a szinonim (pS) és nemszinonim ( $\mathrm{pN}$ ) mutációk arányának ( $\mathrm{pN} / \mathrm{pS}$ ) összevetésével, meg tudjuk határozni az egyes fehérjék és doménjeik evolúciós sebességét [Hurst 2002]. A szinonim mutációknak (S) nincs hatásuk a fenotípusra, ezért nem hat rájuk szelekció, arányuk pedig információt ad az alap mutációs rátáról, mely lókuszonként eltérő lehet. A nem szinonim mutációk ( $N$ ) viszont megjelennek a fenotípusban, ezért hathat rájuk szelekció. Minél több a nem szinonim mutáció két gén között, evolúciósan annál távolabb helyezkednek el. Ha a nem szinonim mutációk arányát (nem szinonim szubsztitúció per nem szinonim szubsztitúciós hely: pN) elosztjuk a szinonim mutációk arányával (szinonim szubsztitúció per szinonim szubsztitúciós hely: pS) egy olyan értéket kapunk (pN/pS), ami az adott fehérje változásának a sebességét írja le és kiküszöböli a lókuszonként eltérő mutációs ráta által okozott esetleges hibát. 
Egy gén evolúciós rátáját minden egyes kodonra kapott $\mathrm{pN} / \mathrm{pS}$ arány átlagából kapjuk. Az egy-egy fehérjét jellemző pN/pS érték tehát statisztikai jellegű, ezért félrevezető lehet, így például, gyors evolúciót mutató fehérje is hordozhat konzervált domént [Yurlova et al. 2009].

A pN/pS értékek relatívak, a számítás során a kapott eredményeket befolyásolhatja a kiválasztott fajok evolúciós távolsága, a felhasznált fajok száma és az illesztések minősége is. Ezért az eredmények validálásának érdekében megvizsgáltam, hogy a teljes fehérjék esetében, hogyan változnak ezek az értékek öt, tizenkettő és huszonegy faj, illetve a paralógok bevonása esetén (10. ábra, A panel). Nem meglepő módon, 5 közeli rokon fajt vizsgálva alacsonyabb pN/pS értékeket tapasztaltunk, mint 12 faj esetén. A 21 fajt vizsgálva viszont nem kaptunk jelentősen eltérő eredményt a 12 faj adataihoz képest. Ez azzal magyarázható, hogy az a kilenc faj, amelyeket bevontunk a kalkulációba, nem jelentenek újabb szélsőértéket, hanem beilleszthetőek a 12 faj rokonsági körébe (10. ábra, B panel). Hasonló eredményeket kaptunk azokban az esetekben is, ahol a paralógok bevonása lehetséges volt (10. ábra). A mintaszámtól és rokonsági foktól függetlenül azt tapasztaltuk, hogy a Globin1 és a HP1 lényegesen alacsonyabb pN/pS értéket mutatnak, mint az azonos fajokból származó Lhr, HOAP, HipHop, Ver vagy DTL fehérjék.

A deléciók és inszerciók jelenléte az illesztésekben nem befolyásolja a szekvenciák között számolt pN/pS értékeket, mert az ürökhöz illeszkedő kodonoknak nem számolható ilyen értéke. 
A)

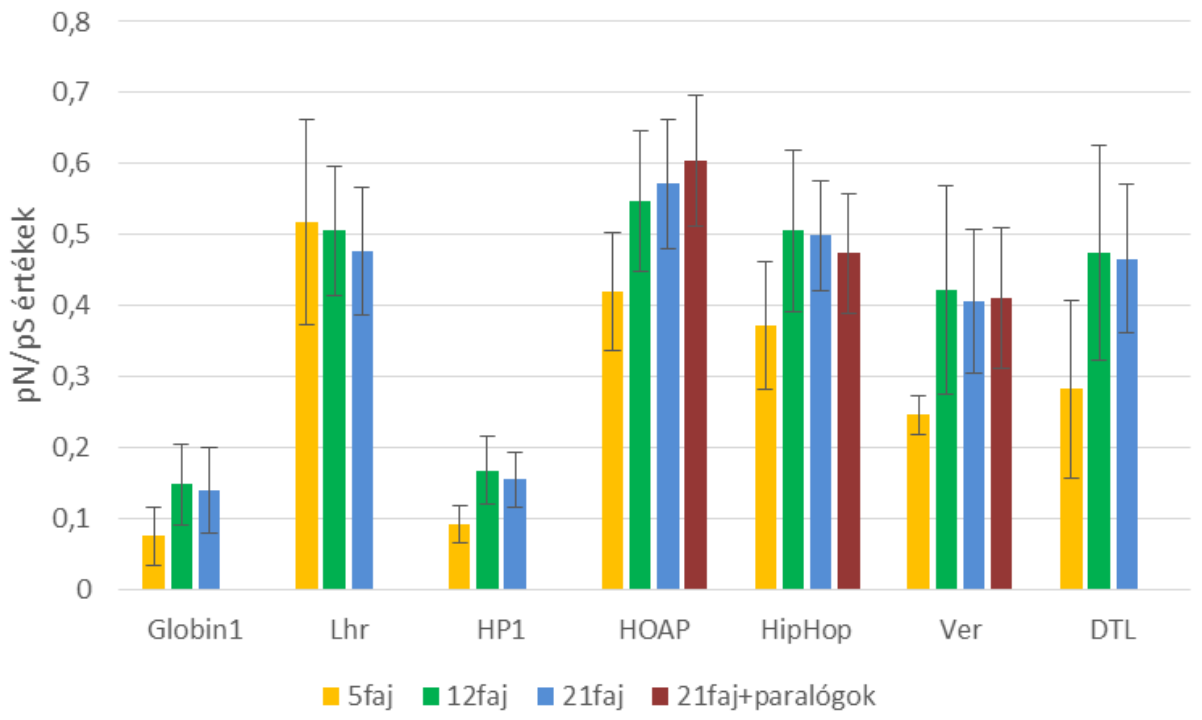

B)

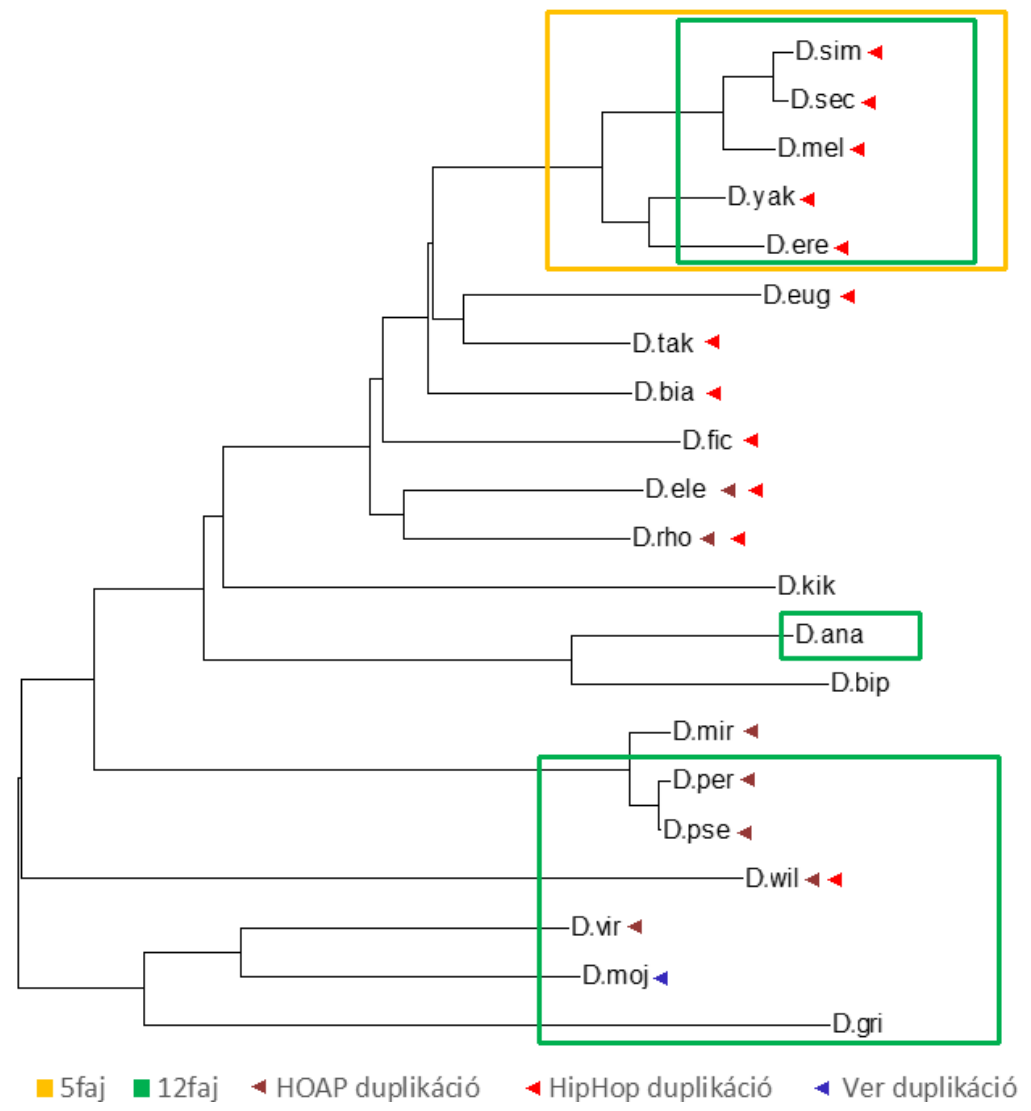

10. ábra: A számolt evolúciós sebesség és a mintaszám összefüggése

(A) A szinonim mutációkra normalizált nem szinonim mutációk eloszlását mutatja az ábra $A$ része, teljes szekvenciákban számolva. A pN/pS értékek változnak a mintaszám és a rokonsági fok függésében, azonban egymáshoz viszonyított értékük közel állandó. A konzervált Globin1 és HP1 mindig alacsonyabb értéket mutat, mint a többi gyorsan evolválódó fehérje. (B) HP1 illesztés alapján maximum-likelihood metódussal számolt fa, mely összeegyeztethető az irodalomban talált adatokkal [Seetharam és Stuart 2013, van der Linde és Houle 2008]. Látszik, hogy az 5 faj esetén számolt értékek a közel rokon fajokra vonatkoznak (sárga keret), míg a 12 faj szélesebb rokonságot ölel fel (zöld keret). A 21 faj nem bővítette tovább a kört, de árnyaltabb eredményt 
várhatunk a bevonásukkal, akárcsak a paralógok esetében. Az ábrán nyilak jelölik azokat a fajokat, ahol legalább egy paralógot találhatunk [Dubruille et al. 2012].

Az irodalomból ismert domének megfeleltethetőek a szekvencia illesztések alapján hasonló konzervációs értékeket mutató régióknak (8. ábra). Ezeknek a régióknak külön-külön meghatároztam az evolúciós sebességét és összevetettem a teljes szekvenciákra kapott értékekkel és egymással is (11. ábra).

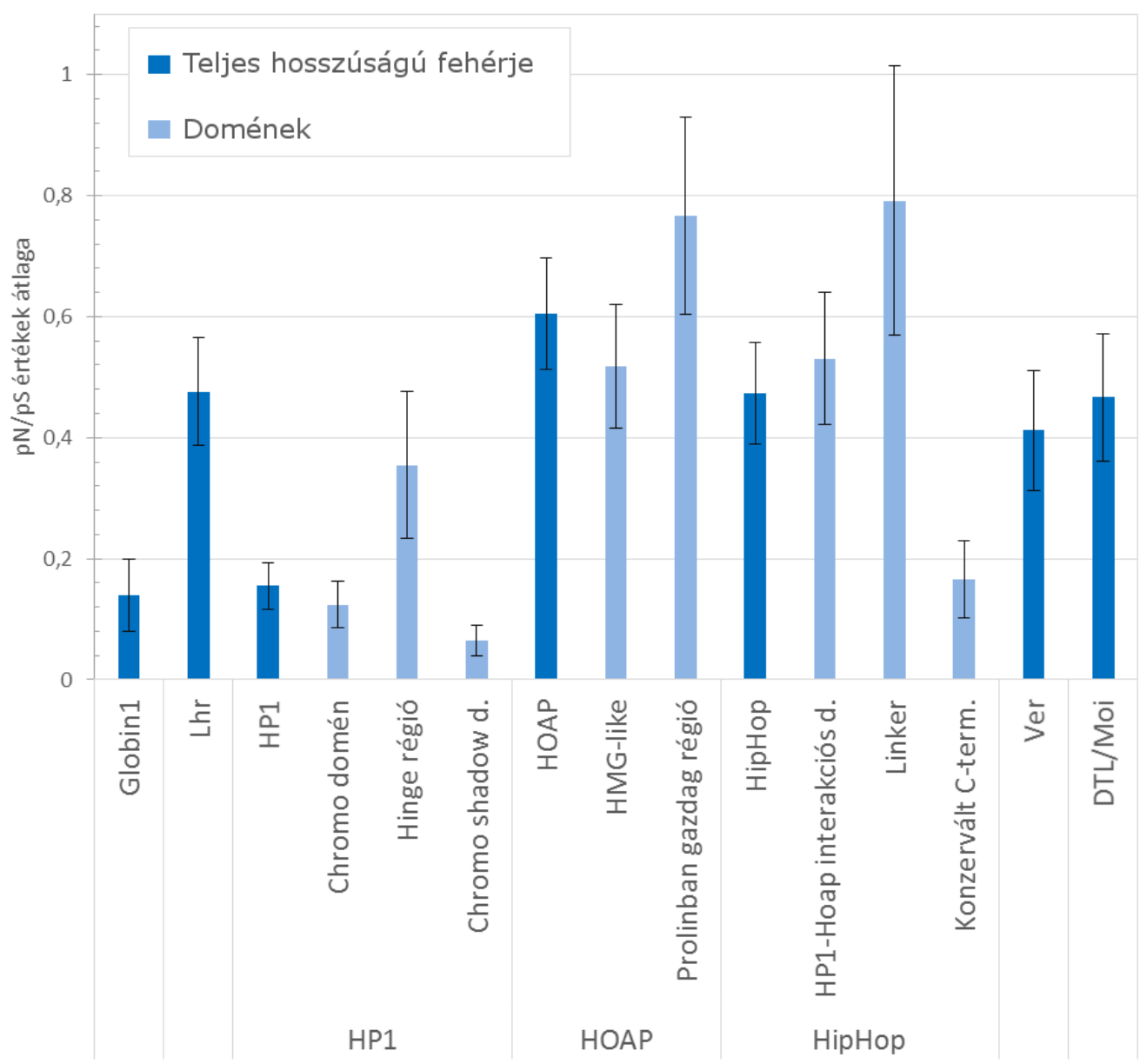

11. ábra: A teljes fehérjék és doménjeik eltérő pN/pS értékekkel rendelkeznek.

A teljes fehérjékre és azok doménjeire számított $\mathrm{pN} / \mathrm{pS}$ értékek oszlopdiagramon lettek ábrázolva. A terminin fehérjék és doménjeik gyorsabb evolúciót mutatnak a konzervált fehérjékhez képest.

A domének evolúciós sebességének meghatározásához az összes rendelkezésre álló szekvenciát felhasználtuk. Eredményeink alapján a HP1 chromo és chromoshadow doménjei erősen konzerváltak. A HipHop C-terminálisán is találunk egy konzervált régiót, ahogy azt Gao és munkatársai már 
korábban leírták [Gao et al. 2011]. A várakozásnak megfelelően az összekötő funkciót ellátó, rendezetlen szerkezetúnek jósolt molekularészek gyors evolúciót mutattak. Azonosítottunk olyan doméneket is, melyek szerepe protein-protein kölcsönhatásban ismert és evolúciójuk felgyorsult. Eredményeink alapján ilyen a HOAP HMG-like régiója, a HipHop HP1-HOAP kölcsönható régiója, a Ver Ob-fold doménje és a DTL nem karakterizált doménje. Ezeknek a doméneknek a vizsgálatával választ kaphatunk olyan kérdésekre, mint például, hogy hogyan hatnak kölcsön a gyorsan evolválódó molekulák, hogyan képesek komplexet alkotni, illetve részt vehetnek-e a fajképzés folyamatában.

\subsection{A Verrocchio szerkezeti modellje}

A fehérjék múködésének megértését nagyban elősegítheti háromdimenziós molekula modellek alkalmazása, azonban a terminin fehérjék esetében nem rendelkezünk térszerkezetre vonatkozó adatokkal. Mivel a terminin fehérjék többsége nem mutat egyértelmű hasonlóságot más fehérjékkel, a lehetőség is korlátozott a homológia alapján történő molekulamodellek készítésére (2-6. függelékek). Kivétel azonban a Ver esete. Ez a fehérje evolúciósan gyorsan változik, és tartalmaz egy ismert szerkezetű domént. A Verrocchióról az Stn1 élesztő fehérjével mutatott homológiáját kihasználva Raffa és munkatársai készítettek térszerkezeti modellt [Raffa et al. 2010]. A Modeller program segítségével reprodukáltam ezt a térszerkezetet, mely szekvencia szinten csak az Ob-fold részt fedi le (12. ábra). A modell fejlesztése érdekében a Phyre2 online felületén készítettem újabb predikciókat (12-13. ábrák). Ebben az esetben, eltérően a Modellertől, nem a felhasználó biztosítja a szekvencia illesztéseket és a homológ szerkezetet, hanem maga a program keres találatokat az adatbázisában, melyek közül több mintát is felhasználhat.
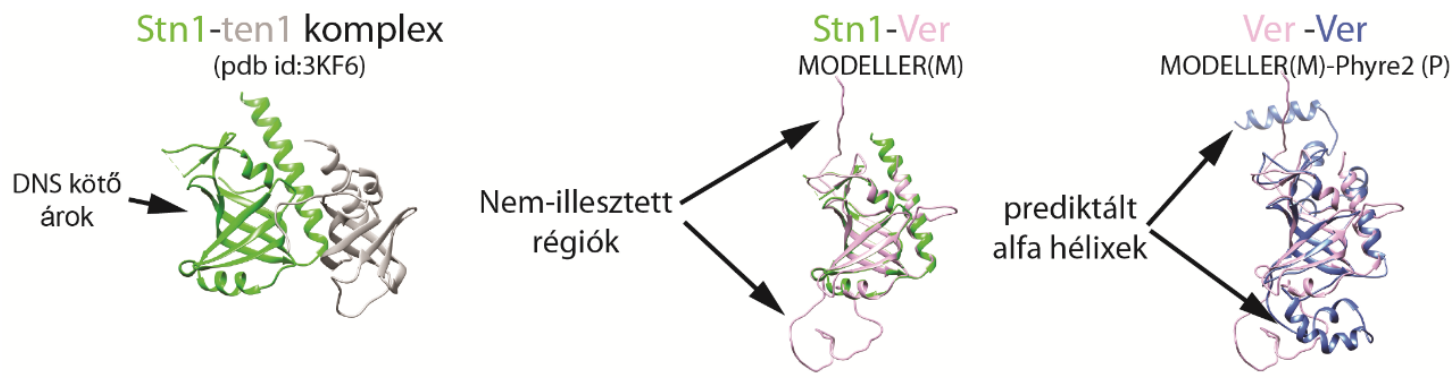

12. ábra: A Verrochio homológia alapú modellezéssel illeszthető az Ob-fold fehérjékre.

Egy (MODELLER), vagy több (Phyre2) templátot felhasználva hasonló térszerkezeti modellt kapunk. Az Stn1 fehérje zöld színnel, a ten1 szürkével, míg a Ver különböző modelljei rózsaszín (MODELLER) és kék (Phyre2) színekkel vannak jelölve. A fehérjék szerkezetét a polipeptid lánc szalag-szerű (ribbon) ábrázolásával mutatjuk be. 
Mivel a Phyre program több véletlen generált lépést is használ a modellezés során, ezért futásonként eltérő eredményt adhat. Ezért többször lefutattam a Drosophila melanogaster Ver szekvenciájára, mely számítások eltérő, de hasonló szerkezeteket eredményeztek (13. ábra, A panel). A Phyre program a szerkezet predikcióhoz kizárólag szekvencia adatokat kér, ezért más fajból származó, eltérő szekvenciájú proteinekre lényegesen eltérő szerkezet predikciót adhat. Rokon fajokból ( $D$. yakuba és $D$. grimshawi) származó Ver szekvenciákat felhasználva azonban a korábbiakhoz hasonló eredményeket kaptunk, ami a szerkezet konzerválódására utal (13. ábra, B panel). Az N-terminális a flexibilitása miatt befolyásolhatja a számításaink eredményét, ezért $\mathrm{N}$-terminálisra nézve csonka fehérjéket is modelleztem, azonban ez a modellek minőségére nem volt jelentős hatással (13. ábra, E panel).

Az eltérő modelleknél a legnagyobb különbségeket az $\mathrm{N}$-terminálison található hélix pozíciója mutatja, melyről eredményeink alapján azt feltételezzük, hogy a magi lokalizációhoz szükséges. A hélix egy rendezetlennek prediktált nyéllel kapcsolódik az Ob-foldhoz (9. ábra), mely megnöveli az ezen a régión található konzervált aminosav szekvencia hozzáférhetőségét, feltehetően az importin fehérjék számára. Egy, a magi lokalizációs szignálok felismerését végző szoftver (cNLS Mapper) találatot adott a 17. és 48. aminosav között, ami megerősíti feltételezésünket, hogy ez a régió magi lokalizációs szignálként múködhet. 


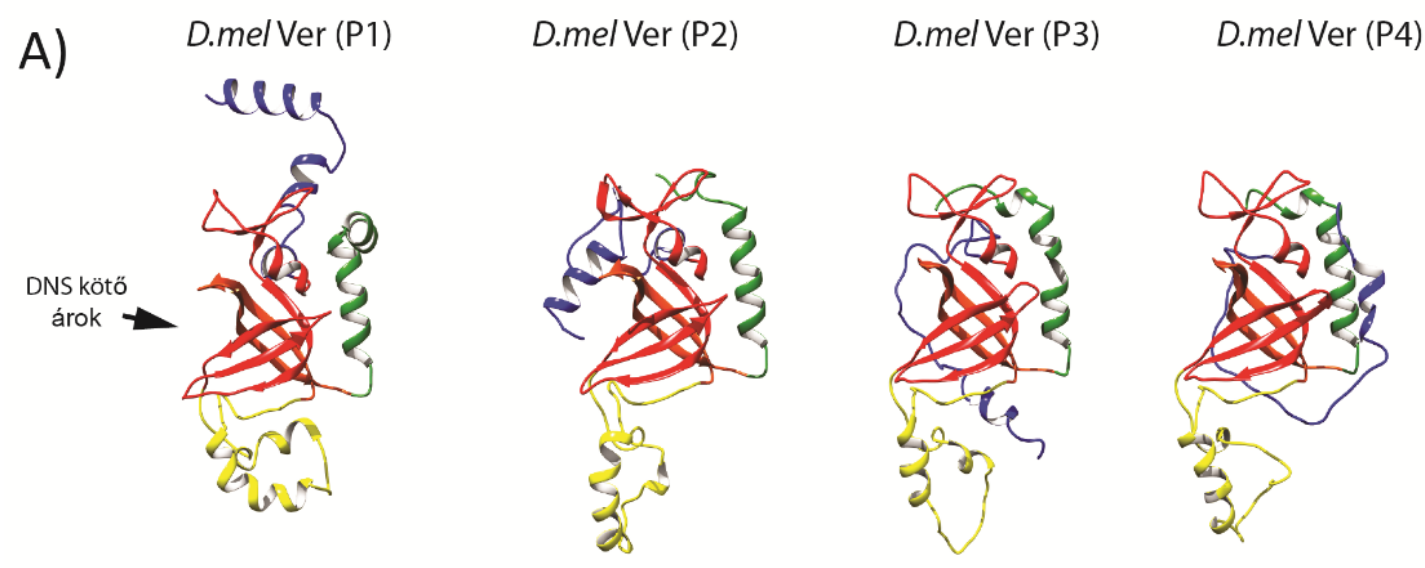

B)

D.yak Ver (P1)

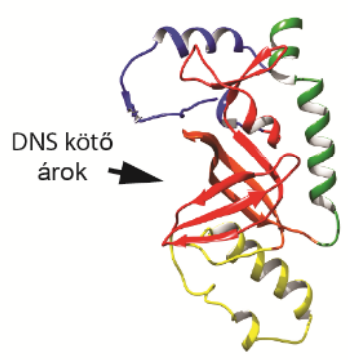

D.yak Ver (P2)

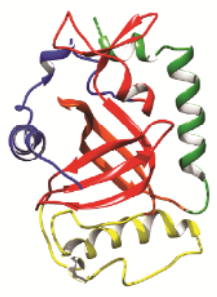

D.griVer (P1)

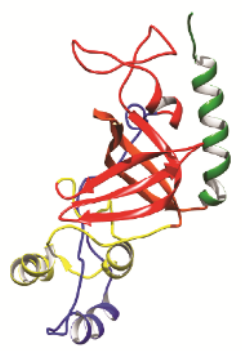

D.gri Ver (P2)

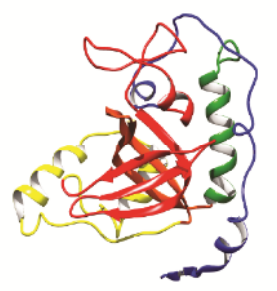

C)

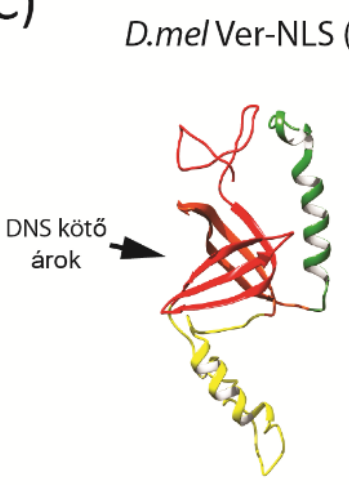

D.mel Ver -NLS(P2)

D.mel Ver-NLS(P3)
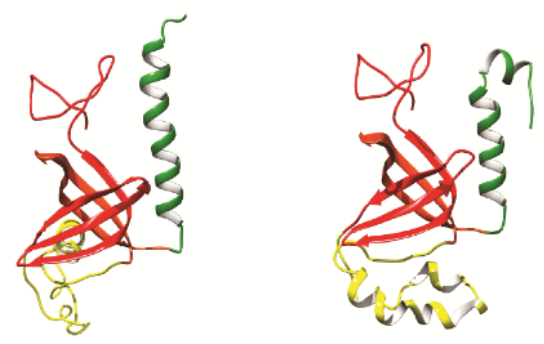

Ob-fold

Ob -fold kapcsolt hélix

Flexibilis N-terminális (NLS)

Változékony helikális

régiók

13. ábra: A Phyre programmal generált Ver térszerkezetek minden vizsgált esetben nagy hasonlóságot mutatnak

(A) D. melanogaster illetve (B) D. yakuba és $D$. grimshawi Ver szekvenciákat felhasználva készített modellek az aminosav sorrendben tapasztalt eltérések ellenére rendkívül hasonlóak. Eltérést az $\mathrm{N}$-terminális mutat, mely a sejtmagi lokalizációs szignált hordozza, illetve a sárgával jelölt, egy vagy két hélixet tartalmazó rész. (C) Az Nterminális eltávolítása nem okozott jelentős változást a szerkezet predikciókban. 
Az eltérések ellenére minden térszerkezetben állandó pont az Ob-fold domén (piros) és a hozzá kapcsolódó alfa hélix (zöld). Az Ob-fold esetében, a feltételezett DNS-kötő árok minden modellen megfigyelhetö.

A Phyre programmal kapott szerkezetekre a Modeller program segítségével illesztettem a másik két vizsgált faj szekvenciáját és az 5 legjobb modellt átfedésben ábrázoltam (14. ábra, A panel). A szekvencia különbségek ellenére (D.mel-D.yak 17\%, D.mel-D.gri 65\%, D.yak-D.gri 64\%) bármelyik fajból származó fehérje illeszthető a másik faj esetén kapott modellre.

Természetesen az illeszthetőség nem jelenti azt, hogy a fehérje valóban felveszi ezt a prediktált szerkezetet. Ha összehasonlítjuk a D.mel Ver (P1) modellre illesztett szerkezeteket D. melanogaster, D. yakuba és $D$. grimshawi esetén, alig tapasztalunk eltérést. Viszont jelentős különbségeket fedezhetünk fel a hidrofobicitás alapján színezett felszínen, ahol D. grimshawii esetén megnövekedett a felületen a hidrofób aminosavak száma (14. ábra, C panel). Ezek a változások a fehérje-fehérje interakcióra is hatással lehetnek.

Azt találtam, hogy habár a Ver térszerkezeti modellek változatosak, alapvető tulajdonságaikban nem különböznek lényegesen, így bármelyik modell vizsgálata esetén értékes következtetéseket tudunk levonni. 


\section{Eltérő fajok szekvenciái Phyre modellre való illeszthetősége}

A)

Templát: $\quad$ D. mel
5-5 legjobb illesztés:

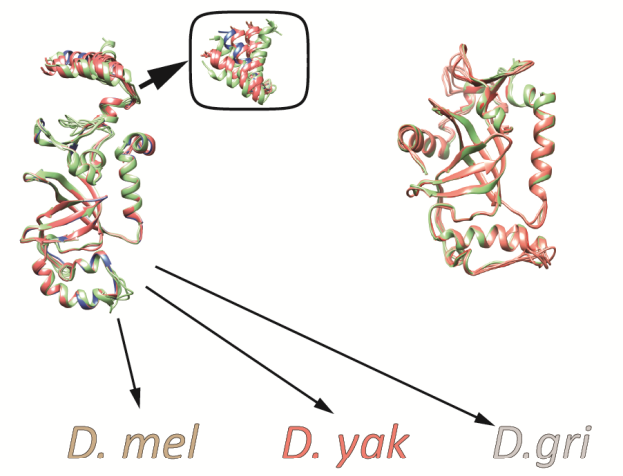

B)

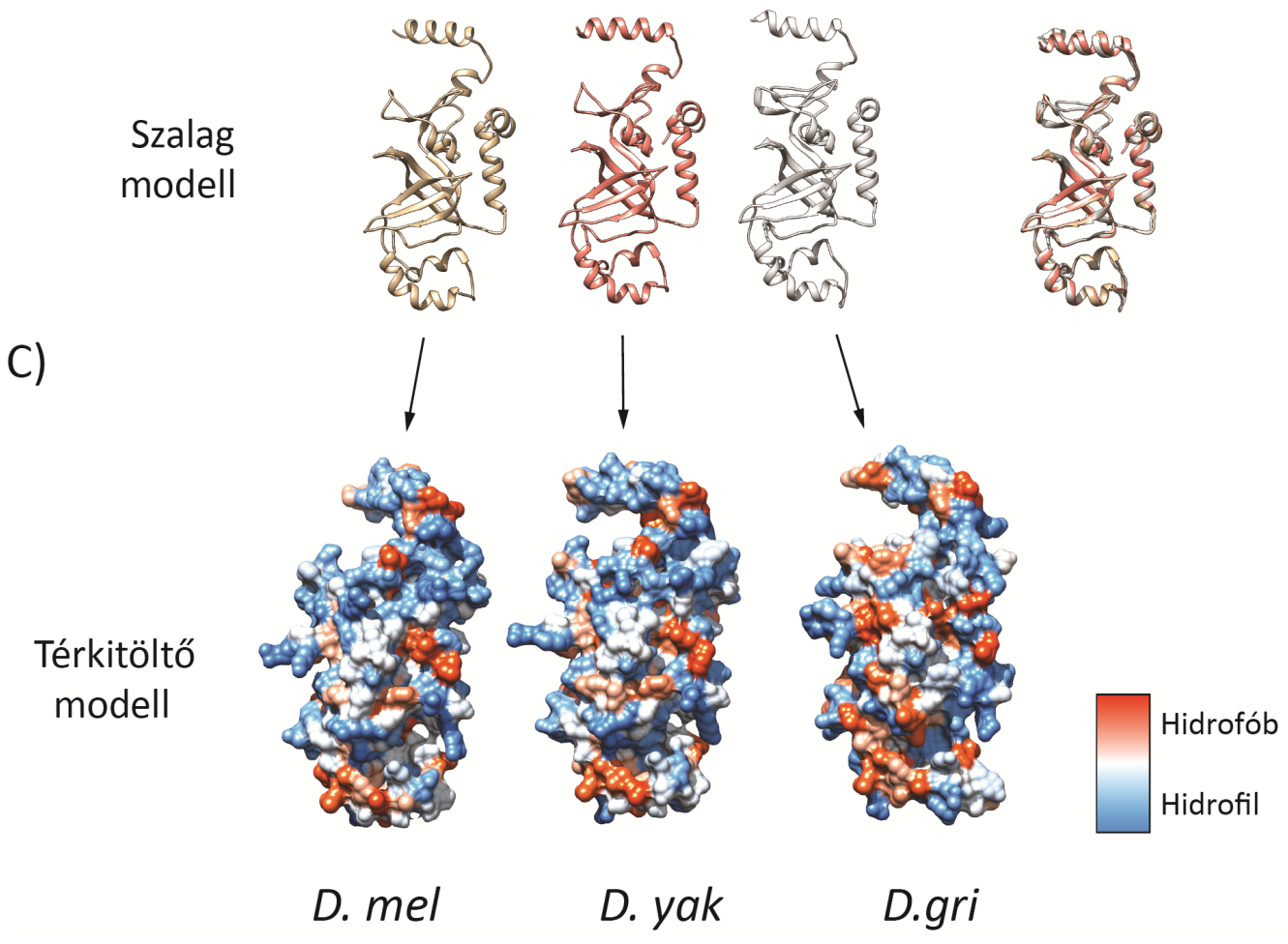

14. ábra: A szekvencia különbségek ellenére hasonló modelleket kapunk $D$. melanogaster, $D$. yakuba és $D$. grimshawi Ver ortológok esetében.

(A) $\mathrm{Az}$ "A" panel első térszerkezete a Phyre2 programmal készített $D$. melanogaster (kék) modell. Ezt a szerkezetet templátként felhasználva elkészítettünk további 5-5 modellt a $D$. yakuba (rózsaszín) és $D$. grimshawi (zöld) szekvenciákra a MODELLER program segítségével. Az ábrán kiemelésre került, hogy a $D$. melanogaster Phyre2 modelljére illesztett szerkezeteknek csak az N-terminális hélixe mutatott kisebb eltérést a kiindulási modellhez képest. Hasonlóan az első térszerkezetekhez, a második és harmadik modell a másik két vizsgált faj Phyre2 modelljeire (D. yakuba (piros) és $D$. grimshawi (szürke)) illesztett MODELLER predikciókat jelentik. A harmadik modellen ( $D$. grimshawi templát) nyílhegy jelöli a nem illeszthető szakaszokat, melyek jelenléte abból fakad, hogy $D$. grimshawi Ver fehérje 6 aminosavval rövidebb, mint $D$. melanogaster és $D$. yakuba fehérjék. (B) A $D$. melanogasterre legjobban illeszkedő $D$. yakuba és $D$. grimshawi modellek szalag ábrázolása minimális eltéréseket mutat. (C) Azonos szalagmodellek térkitöltő modellije látható a " $\mathrm{C}^{\prime \prime}$ panelen. $\mathrm{A}$ felszín színezete az aminosavak hidrofobicitásának megfelelő. Habár szalag ábrázolásban az egyezés nagyfokú a vizsgált fehérjéink esetében, az eltérő szekvencia miatt a felszínre kerülő aminosavak jellege különbözhet. 
Például a D.mel Ver (P1) modellt mintaként használva D.gri szerkezet esetén jelentős hidrofób felületnövekedést tapasztalunk, ami kedvezőtlen energia viszonyokat eredményez.

További térszerkezet elemzésekhez a D.mel Ver (P1) modellt választottam ki, mert a flexibilis sejtmagi lokalizációs szignál ebben az esetben jól elkülönül a fehérje többi részétool. Ha megnézzük a szerkezetet az aminosav konzerváltságnak megfelelően színezve, láthatjuk, hogy a konzervált aminosavak főként a helyes térszerkezet kialakításában vesznek részt (15. ábra). Az Ob-foldot kialakító aminosavak a fehérje belseje felé fordulnak, míg az Ob-fold és a hozzá kapcsolt hélix kölcsönhatásában részt vevő aminosavak a struktúra szervezésen kívül egy konzervált felszínt alakítanak ki. Konzerváltságot mutat még a DNS-kötő felszín, illetve az N-terminálison található sejtmagi lokalizációért felelős szignál peptid is. A korábban sárgával ábrázolt (13. ábra) változékony hélixek esetében a konzervált aminosavak pozíciója modellenként változik ugyan, de megfelelő elhelyezkedésük esetén alkothatnak egy kisebb konzervált felszínt.

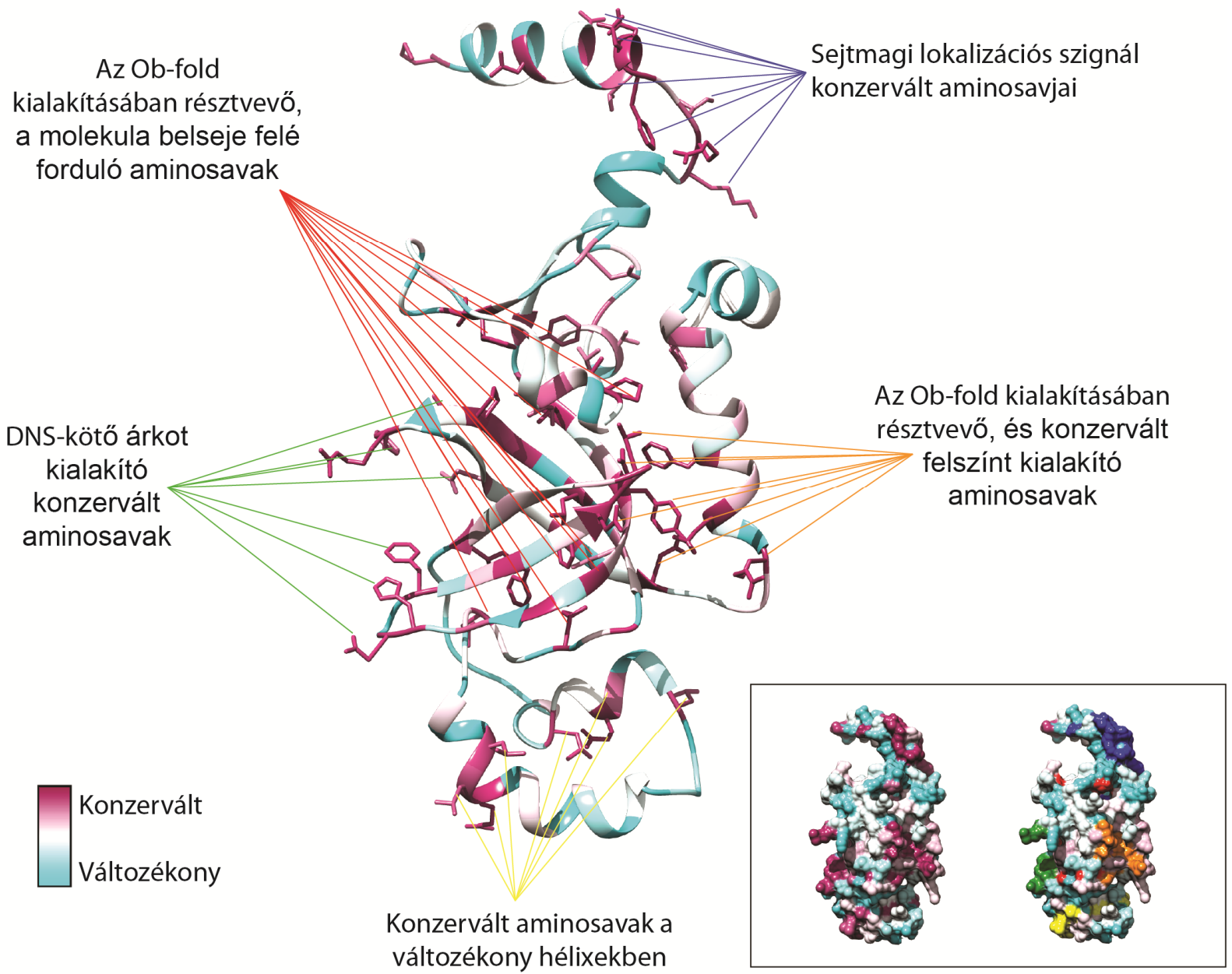

15. ábra: Ver felszínén konzervált aminosavakból kialakuló felszíneket azonosíthatunk

A konzervált aminosavakat öt csoportba oszthatjuk a feltételezett funkcióik alapján melyek a következők: a sejtmagi lokalizációs szignált kialakító aminosavak (kék), az Ob-fold kialakulásában részt vevő, a molekula 
belseje felé forduló aminosavak (piros), az Ob-fold kialakításában szerepet játszó, konzervált felszínt is kialakító aminosavak (narancssárga), DNS kötő árkot kialakító aminosavak (zöld), a változékony hélix konzervált aminosavai (sárga). A kis képen két térkitöltő modell látható. Az első konzerváltság szerint színezett modellt, míg a másik a csoportosításnak megfelelően színezett felszíneket mutatja. A második ábrán piros színezés alig látható, míg a többi aminosav konzervált felszíneket alakíthat ki.

A Ver térszerkezetének elemzése során konzervált felszíneket azonosítottunk, melyek közül egyik az irodalom szerint feltehetően a DNS-kötésért felel, egy másik pedig a sejtmagi lokalizációt biztosító importin fehérjék felismerési szekvenciája. A többi konzervált felszín szerepét nem ismerjük, azonban elképzelhető, hogy a többi terminin fehérje kötéséhez szükséges felszínt biztosítják. Ez magyarázhatja, hogy a fehérjék közötti kölcsönhatások miért maradnak stabilak a gyors evolúció ellenére. Ez utóbbi esetben kevésbé valószínű, hogy fehérjék szerepet játszanak a fajképzésben, hiszen bár a fehérje domének evolúciója gyors, a fehérjék szerkezete mégis konzervált, aminek köszönhetően az interakciókban részt vevő konzervált aminosavak megfelelően pozícionálhatóak az interakciók kialakításához.

\subsection{A terminin fehérjék heterológ expressziója}

A terminin fehérjék közötti kölcsönhatásokat genetikai módszerekkel és GST-pull down kísérleteket alkalmazva korábban is vizsgálták (16. ábra). A kísérleti adatok szerint a Ver interakcióba lép a DTL-lel és a HOAP-pal [Raffa et al. 2010], a DTL interakcióba lép a Ver, a HOAP és a HP1 proteinekkel [Raffa et al. 2009], míg a HipHop kölcsön hat a HP1-gyel és a HOAP-pal, de nem lép kölcsönhatásba a Ver vagy a DTL fehérjékkel [Raffa et al. 2009, Gao et al. 2010, Raffa et al. 2010]. Azért, hogy más módszerrel is igazoljuk e kölcsönhatások és a terminin komplex létezését, továbbá, hogy megvizsgáljuk a gyorsan változó domének kölcsönhatásait és esetleges szerepüket a fajképzésben, bakteriális expressziós rendszerben termeltettük a terminin fehérjéket.

50. 


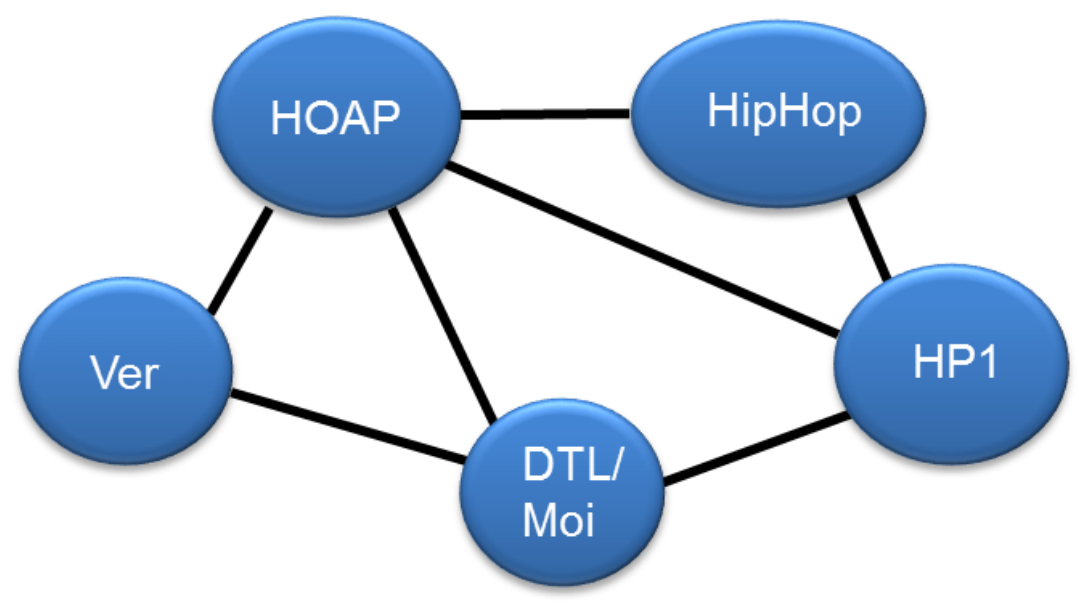

16. ábra: Terminin fehérjék között kimutatott kölcsönhatások

A kék körök a terminin fehérjéket mutatják, míg a vonalak a köztük lévő kölcsönhatásokat. A kölcsönhatások kimutatása főként GST-pull down kísérletekkel történt, heterológ fehérjék felhasználásával [Raffa et al. 2009, 2010, Gao et al. 2010].

Annak érdekében, hogy a proteinek natív térszerkezete ne torzuljon, és egy hozzáadott epitóp ne befolyásolja a komplex összeszerelődését, először jelöletlen („tag” nélküli) fehérjéket termelő plazmidokat állítottam elő. Később, amikor egyes esetekben indokolttá vált, haemagglutinin (HA) illetve hisztidin (his) jelölést használtam. A klónozás részleteit az Anyagok és módszerek fejezetben, a monocisztronos és policisztronos konstrukciók előállítása alpontban fejtettem ki (3.2.9).

Monocisztronos plazmidokról történő indukciót követően jól kimutatható mennyiségű fehérje termelődött a HP1, a HOAP, a Ver és a DTL fehérjékből (17. ábra).
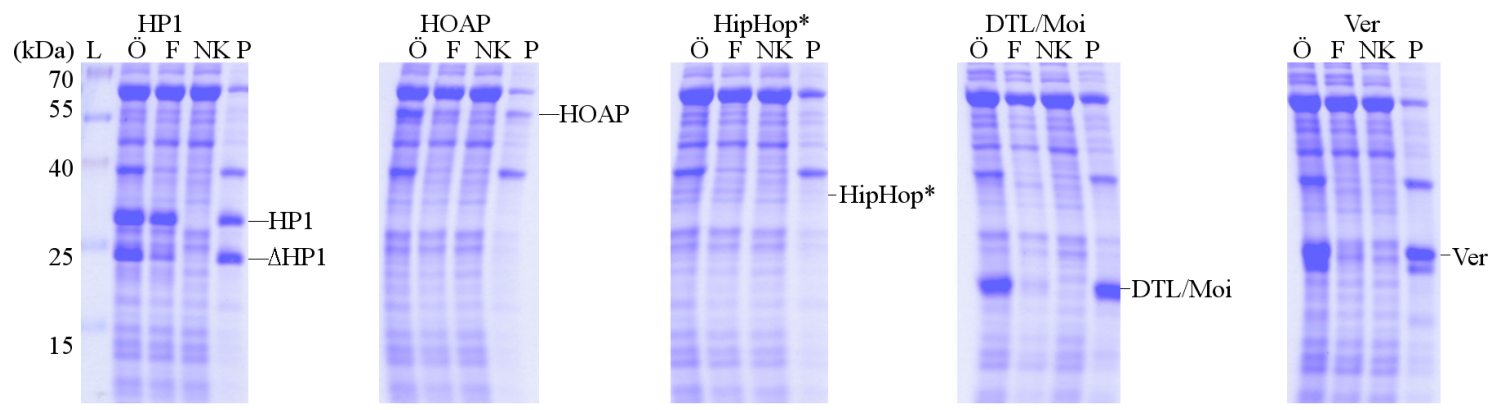

17. ábra: A Drosophila terminin fehérjék egyenként különböző mértékben oldható formában termeltethetők baktériumsejtekben

A terminin fehérjét expresszált baktérium sejt lizátumok PAGE gél fotója. A képen látható expresszált fehérjék minden esetben jelölve. L: molekulatömeg marker (létra - egy gélt látunk több darabba vágva, így a marker az 
ábra minden részével összevethető); Ö: teljes sejt lizátum F: oldható frakció; NK: nem indukált sejtek oldható frakció - kontroll; P: oldhatatlan csapadék frakció (pellet). A sejtextraktumot (Ö) centrifugálva elkülöníthetjük annak oldható (F) és oldhatatlan frakcióit (P). A heterológ fehérje expresszió során gyakori, hogy a termelt fehérje a csapadékban fordul elő, ,"inclusion body"-t képezve.

Az önmagukban termeltetett terminin fehérjék oldhatósága változó. A termelődött HP1 és HOAP fehérjék körülbelül fele jelent meg a felülúszóban (F), míg a DTL és a Ver túlnyomó többsége a csapadékban található (P) (Arctic Expressz $18^{\circ} \mathrm{C}$ ). Az alacsony expressziós szintje miatt, a HipHop termelődése nem látszik a gélen, viszont a fehérje várt pozícióját csillaggal megjelöltük.

A csapadékokban (P) látható 60 és 40 kDa körül megjelenő proteinek bakteriális eredetűek; dajka fehérjék (60 $\mathrm{kDa})$, sejtfalhoz ( $40 \mathrm{kDa}$ ) asszociált fehérjék, vagy antibiotikum rezisztenciához szükséges fehérjék is lehetnek.

A HipHop expresszió a termeltetés körülményeitől függetlenül (hőmérséklet, indukálószer koncentrációja, tápoldat), mindig alacsony szintet mutatott. Az alacsony HipHop expresszió magyarázható azzal, hogy a baktériumok és a Drosophila sejtek eltérő gyakorisággal használnak bizonyos kodonokat, és tRNS-eket. Ezért a BL21 expressziós baktériumtörzset Rosetta sejtekre cseréltük, mely baktériumban ritka tRNS-eket kódoló plazmidot hordoz. Azonban a Rosetta sejtekben történő fehérje termelés sem fokozta a HipHop mennyiségét. Mivel a denaturáló gélen a HipHop kimutathatatlan volt, a követhetőség érdekében a fehérjét HA epitóppal jelöltem. A HipHop a későbbi vizsgálatok során stabilnak bizonyult.

Bakteriális rendszerben a HP1 kódoló régióról két fehérje képződött (17. ábra). A két fehérje megjelenését alternatív start kodon nem indokolta. $\mathrm{N}$-terminális hisztidin tag jelölést követően csak a nagyobb fehérje futási magassága változott, ami a protein $\mathrm{N}$-terminálisának degradációjára utal. Ezt megerősíti a később végzett tömegspektrometria: mindkét termelődött fehérjét HP1-ként azonosítottuk, azonban a kisebb fehérje esetén az N-terminálison nem volt peptid találat (19. ábra, B panel).

A Ver és a DTL expressziós szintje megfelelő ugyan, és degradáció sem jellemző rájuk, azonban, míg a többi protein az oldatban marad, addig a Ver és a DTL oldhatatlan formában (inclusion body) képződik (17. ábra). Ezt úgy vizsgáltuk meg, hogy a feltárt sejteket nagy fordulatszámon centrifugáltuk, melynek köszönhetően elkülönítettük az oldható fehérjéket (felülúszó) az oldhatatlan aggregátumot képző fehérjéktől (csapadék). A pelletben lévő fehérjék nem alkalmasak biokémiai vizsgálatokhoz, ezért a fehérjék oldható formában való termelésének kedvező körülményeket biztosítottunk az indukció során. A fehérje oldhatóságát növelheti a fehérje termelődés ütemének lassítása, az indukálószer koncentrációjának csökkentése, vagy az indukálás során alacsonyabb hőmérséklet alkalmazása [Rosano és Ceccarelli 2014]. Így a képződő fehérjének több idő áll a rendelkezésére a helyes térszerkezet felvételéhez. Az Arctic Express sejtek hideg sokk proteineket 
hordoznak, melyek lehetővé teszik a kultúra $18^{\circ} \mathrm{C}$-on és az alatt történő növesztését. Esetünkben sem a Ver, sem a DTL oldhatósága nem növekedett jelentősen az említett módszerek alkalmazásával.

Az oldhatóságot fokozhatja még, ha a fehérje interakciós partnere jelen van a termelődés során [Henricksen et al. 1994, Yao et al. 2003, Diebold et al. 2011]. Az oldhatóság növelése érdekében olyan plazmidokat hoztam létre, melyek policisztronos formában koexpresszálják a fenti fehérjéket. A koexpressziós kísérleteket Arctic Express sejtekben végeztem.

A HOAP és a HP1 együtt történő termelése során mind a HP1, mind a HOAP oldhatósága jelentősen javult, szinte az összes fehérje a felülúszóban található (18. ábra). Ver és HOAP vagy Ver, HOAP és HP1 koexpresszió során azonban a Ver esetében nem tapasztaltunk változást. Amikor viszont a DTL is megjelent a sejtben, mind a négy fehérje termeltethető lett oldható formában (18. ábra). A fehérjék oldhatóságának javulása feltehetően a fehérjék között kialakuló interakcióknak köszönhető. A HOAP és a HP1 interakciója Ver fehérjével nem bizonyult annyira jelentősnek, hogy Ver oldhatóságát javítsa.

Elkészítettem az öt terminin fehérje egyidejű termelését biztosító plazmidot is, de a HipHop továbbra is rendkívül alacsony expressziós szintet mutatott, és nem volt érdemi hatással a többi fehérje oldhatóságára.
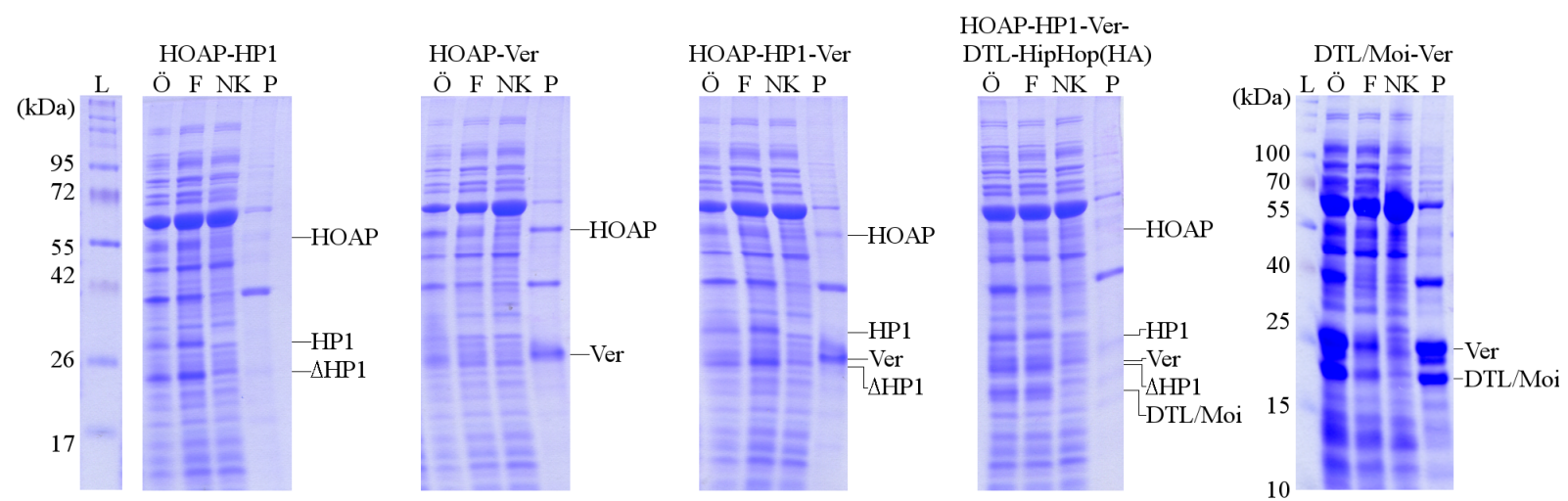

18. ábra: A baktériumsejtekben termelt terminin fehérjék oldhatóságát kölcsönható partnereik jelenléte megnöveli

A terminin fehérjéket koexpresszáló baktériumok lizátumának PAGE gél fotója. A HOAP és a HP1 koexpressziója esetén mindkét fehérje oldhatósága jelentősen fokozódik és a fehérjék túlnyomó többsége a felülúszóban (F) és nem a csapadékban (P) látható. A Ver viszont a HOAP és a HP1 jelenléte esetén is nagyrészt a csapadékban (P) van. Azonban, ha DTL is jelen van az expresszió során, akkor valamennyi fehérje kimutatható az oldható frakcióban (F) is. A Ver és a DTL koexpressziója is fokozta a fehérjék oldhatóságát.

L: molekulatömeg marker (létra); Ö: összes sejt lizátum - centrifugálatlan minta; F: felülúszó minta; NK: nem indukált felülúszó kontroll; P: csapadék (pellet) 


\subsection{A terminin fehérjék tisztításuk során két alkomplexet formálnak}

A hipotetikus terminin komplex további vizsgálatára a policisztronos vektorról termelt négy fehérjét (HP1, HOAP, Ver, DTL) tartalmazó sejt extraktumot heparin-sepharose oszlopra vittem, mert a heparin kromatográfia jól alkalmazható DNS-kötő fehérjék tisztítására. Az általunk a feltárás során használt puffer sem pH-ban sem ionerősségben nem különbözik lényegesen a fehérjék interakcióját leíró pull-down kísérletek során alkalmazottól, ezért nem valószínű, hogy a komplex a feltárás során szétesne. Ennek megfelelően amennyiben a terminin fehérjék a hipotézisünknek megfelelően egy stabil komplexet alkotnak, az egyes fehérjék együttes tisztulását várjuk. Ezzel szemben azt tapasztaltuk, hogy míg a Ver és a DTL alacsony sókoncentráció mellett (200-300 mM NaCl), addig a HP1 és a HOAP magasabb sókoncentráció mellett (500-700 mM NaCl), jól elkülöníthető frakciókban eluálhatók az oszlopról (19. ábra, A panel). Az eluált fehérjéket tömegspektrometriával is azonosítottuk (19. ábra, B panel). Mivel a koexpresszió során kevesebb HOAP fehérje termelődött, mint HP1, a HP1 fehérjék egy részének nem jutott HOAP interakciós partner, ezért láthatunk szabad HP1 fehérjéket 5-6. frakciókban. A kölcsönható partner nélkül tisztított HP1 proteinekre jellemző ez az elúciós mintázat. 


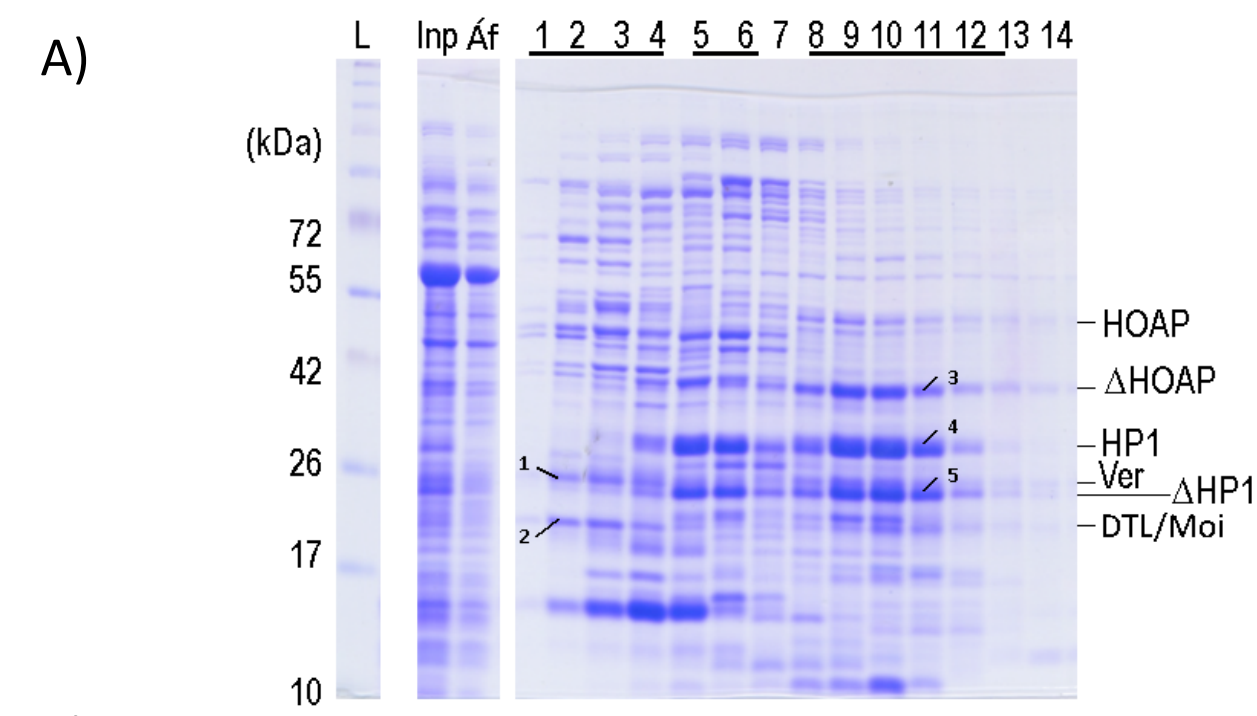

B)

\begin{tabular}{|c|c|c|c|c|}
\hline \# & $\begin{array}{l}\text { Felismert } \\
\text { fehérje }\end{array}$ & $\begin{array}{l}\text { Peptid } \\
\text { találatok } \\
\text { száma }\end{array}$ & $\begin{array}{l}\text { Szekvencia } \\
\text { lefedettség } \\
(\%)\end{array}$ & Szekvencia lefedettsége \\
\hline 1 & Ver & 19 & $73,8 \%$ & $\begin{array}{l}\text { MDFNQSFEDIESQLDNFVIRKNQQSEKSTGKCGPEVHDNVPLTISQIERATQDPENENVFITDDVHPIHFCTCIIYAFVTGNGTHNESFM } \\
\text { KFMIDDGTGSLEASITKKPFNGRVISSLYSEASSLASSEAYKSIAVSMMRLLOVSMEYIDPTRISRGHSLFLRGRPNRFRGKMGLDAFQFFID } \\
\text { SGRSRNMEIGFVDYLTDWQRRHKTMQNTNK }\end{array}$ \\
\hline 2 & DTL/Moi & 14 & $74,2 \%$ & $\begin{array}{l}\text { MSLVPEASTSRAPKYCYFFKTLLVEELELETSYHNLHYGOCALIGRLAFKANQYRLENVRVKCLPKKYYLLGEGTVSLLILGLTHDKVVENRVST } \\
\text { GRYCIVRGEWVLHNVOHPKGAKLTAGGVYDKINSLSNDPLAQKQYLSALLATYRPAIDLWYIQVIDRAEDLITRRLEMRSLIEK }\end{array}$ \\
\hline 3 & $\triangle \mathrm{HOAP}$ & 16 & $28,1 \%$ & $\begin{array}{l}\text { MLLLLCVNMSGTQMSAFLRKYLADEDKKIRAQFKESDPNNKLLLWMHEKTRITEEDLARPYTEDEVKELLCLRTKVKVDMTAWNCLWEAKK } \\
\text { RFEAKGRFVNKSERFINRMYMKAVRRKMVQPYPEEFVAQRREIVAAETKKONISRLDRWOKKKSQNLSAPESSPDAHASSNDAVQSHEDQ } \\
\text { ANTNLSSLSQMNFQVEAMAPPGVSSSDLSGIGDDEDEQQQSGFQDENINRPETEINENSVRCDPINLGRMRTGCINSQANNSFRNTESDP } \\
\text { DWMFGTQLSTLVRPTSTQEPDDQVNCPETEMNESWVRCDQINSESLSIGPSIDSEGTITFQNTESEPIDVTSIA }\end{array}$ \\
\hline 4 & HP1 & 24 & $68,4 \%$ & $\begin{array}{l}\text { MGKKIDNPESSAKVSDAEEEEEEYAVEKIIDRRVRKGKVEYYKWKGYPETENTWEPENNLDCQDLIQQYEASRKDEEKSAASKKDRPSSSAK } \\
\text { AKETQGRASSSTSTASKRKSEEPTAPSGNKSKRTDAEQDTIPVSGSTGFDRGLEAEKILGASDNNGRLTFLIOFKGVDQAEMVPSSVANEKIP } \\
\text { RMVIHFYEERLSWYSDNED }\end{array}$ \\
\hline 5 & $\triangle \mathrm{HP1}$ & 26 & $69,9 \%$ & $\begin{array}{l}\text { MGKKIDNPESSAKVSDAEEEEEEYAVEKIIDRRVRKGKVEYYKWWKGYPETENTWEPENNLDCQDLIQQYEASRKDEEKSAASKKDRPSSSAK } \\
\text { AKETOGRASSSTSTASKRKSEEPTAPSGNKSKRTDAEQDTIPVSGSTGFDRGLEAEKILGASDNNGRLTFLIQFKGVDQAEMVPSSVANEKIP } \\
\text { RMVIHFYEERLSWYSDNED }\end{array}$ \\
\hline
\end{tabular}

19. ábra: Bakteriális eredetű fehérjék parciális tisztítása heparin-sepharose oszlopon

(A) A fehérje tisztítás során gyüjtött frakciók PAGE gél fotója. Az oszlopra felvitt sejtextraktum (Inp) és az átfolyó (Áf) összehasonlítva láthatjuk, hogy a fehérjék egy része, a heterológ fehérjékkel együtt, eltűnik az átfolyóból, ami arra utal, hogy ezek a fehérjék kötődtek a heparin-sepharose oszlopra. Azonban a felkötődött terminin fehérjék eltérő sókoncentráció mellett eluálódtak (1-14). A Ver és a DTL alacsony só koncentrációnál $(0,2-0,3 \mathrm{M} \mathrm{NaCl})$ az 1-4. frakciókban távozott míg HOAP és HP1 a 8-12. frakciókban (0,5-07 M NaCl). (B) Az ábra "A" részén számokkal megjelölt fehérjesávok identitásának meghatározása tömegspektrometriával történt. $\mathrm{Az}$ aminosav szekvenciában az aláhúzott részek a tömegspektrometriával azonosított peptid részeket jelölik.

A holokomplex nem alakult ki abban az esetben sem, ha mind az öt fehérjét tartalmazó sejtextraktumot használtuk a tisztításhoz. Viszont a haemagglutinin jelölt HipHop fehérjét - nem meglepő módon - a HOAP és a HP1 proteinekkel azonos frakciókban sikerült kimutatni (20. ábra). 


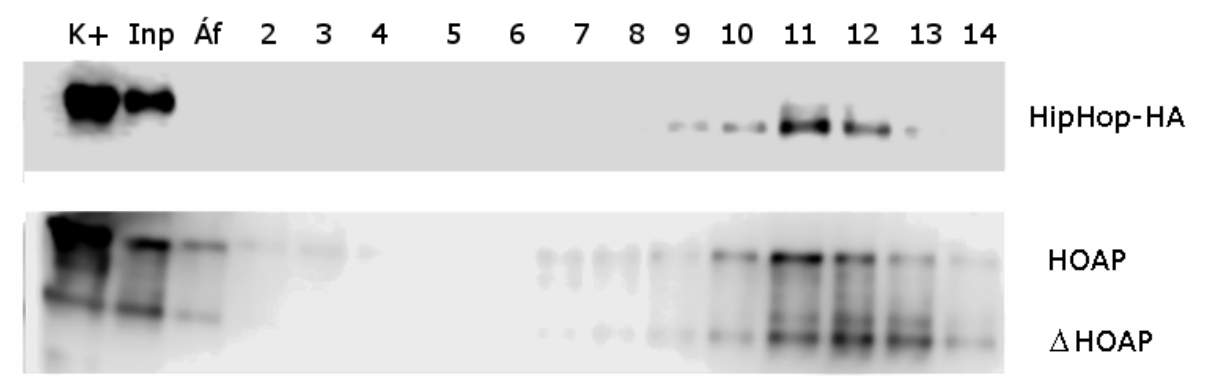

20. ábra: A HipHop a HOAP-pal és a HP1-gyel azonos frakciókban tisztul kromatográfia során

A HipHop fehérje kimutatása western blottal a heparin-sepharose oszlopról távozó frakciókban. Az oszlopra felvitt sejtextraktumot (Inp) összehasonlítva az oszlopon átfolyt fehérjékkel (Áf) láthatjuk, hogy HipHop kötött az oszlopra. Az elúció során HipHop a 9-13. frakciókban jelent meg, ami megfelel a HOAP elúciós mintázatának is $(0,5-07 \mathrm{M} \mathrm{NaCl})$. A HOAP elleni ellenanyag a fehérje csonkolt formáihoz is köt (delta HOAP) ezért látunk több jelet az alsó western bloton.

L: molekulatömeg marker (létra); Inp: input az oszlopra felvitt minta, Áf: átfolyó, a számok az elúció során gyűjtött frakciókat jelölik.

Az, hogy terminin fehérjék nem azonos frakciókban találhatóak, magyarázható azzal, hogy az oszlopról történő elúció során az emelkedő sókoncentráció miatt, a holokomplex két alegységre esik szét. A bakteriális sejtextraktum alacsony só koncentráción történő vizsgálata méretkizárásos kromatográfiával (gélszűrés) lehetővé teszi a kérdés megválaszolását, azonban a fehérjék poliakrilamid gélen történő megbízható azonosítása a sejtextraktum heterogenitása, (és specifikus ellenanyagok hiánya) miatt nehezen elképzelhető. Ezért a heparin-sepharose oszlopon már tisztított terminin fehérjéket használtuk fel méretkizárásos kromatográfiához. A terminin fehérjéket tartalmazó frakciókat alacsony sókoncentráció mellett újra egyesítettük, és gélszűréssel vizsgáltuk, hogy a komplex tagjai együtt eluálódnak-e. A heparin-sepharose oszlopon tisztított frakciók komplexitása lényegesen kisebb, mint a bakteriális sejt extraktumé, ezért gélszürés során a heterológ fehérjék méretük alapján azonosíthatóak.

Az oszlop kalibrációját az SDS-PAGE Standard (Biorad) protein létra tagjainak natív gélszűrésével végeztük. Meghatároztuk, hogy a protein létra egyes tagjai a felviteltől számított melyik térfogat egységben távoznak az oszlopról. A frakciók gyűjtése viszont nem standardizált módon történt, ezért eltérések figyelhetőek meg a mostani és a később bemutatásra kerülő gélszűrések frakcióinak számozásában. Ezért a 116kDa, a 66kDa és 45kDa méretű fehérjéknek megfelelő térfogat egységeket minden ábrán jelöltem.

A méretkizárásos kromatográfia során továbbra is két alkomplexet találunk (21. ábra). A Ver és a DTL heterodimert formál, és ennek megfelelően 45 kDa méretű fehérjének megfelelő frakcióban távozott az oszlopról. A HOAP és a HP1 esetén viszont bonyolultabb a helyzet, mert mindkét fehérje csonkolt formája is jelen van a tisztítás során. A tömegspektometriai mérések alapján a HOAP fehérjének a 
prolinban gazdag C-terminálisa degradálódott, míg a fehérje globuláris HMG-like doménje stabil (40 kDa). Hasonló degradációt figyeltek meg Badugu és munkatársai is [Badugu et al. 2003].

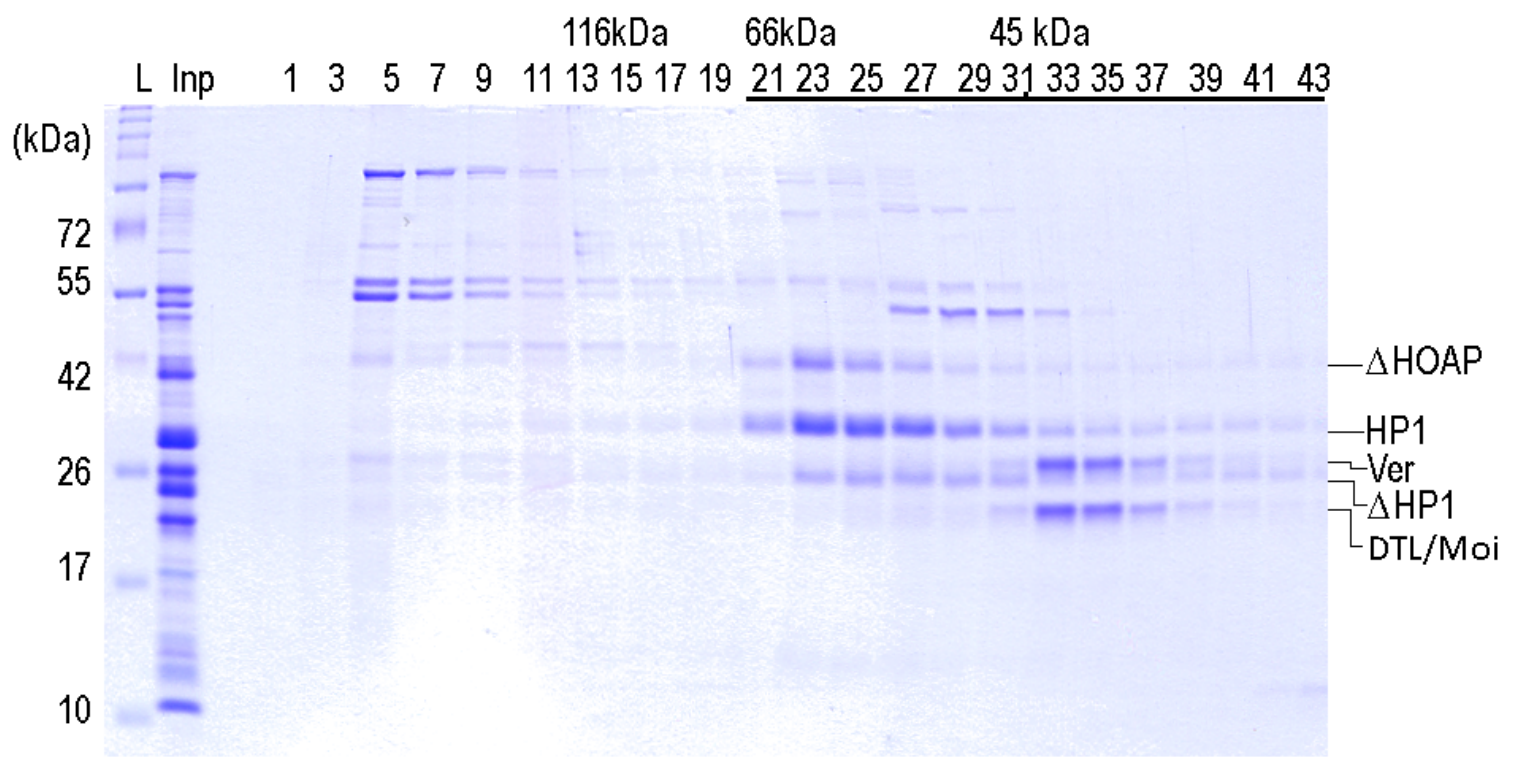

21. ábra: A terminin fehérjék két alkomplexet alkotnak gélszürés során.

A méretkizárásos kromatográfia során kapott frakciókat poliakrilamid gélen futtattam és elemeztem. A terminin fehérjék alacsony sókoncentráció (100 mM NaCl) mellett történő újraegyesítése során nem alakul ki holokomplex, a HP1-HOAP és a Ver-DTL alkomplexek külön-külön hagyják el gélszürés során az oszlopot.

L: molekulatömeg marker (létra); Inp: alacsony sókoncentráción (100 mM NaCl) egyesített heparin-sepharose oszlopról származó frakciók; a számok a gyüjtött frakciókat jelölik.

A heparin-sepharose oszlopon való tisztítás után, a gélen való festődés alapján úgy túnt, hogy 1 HOAP molekulához 2 HP1 tartozik, azonban a gélszürés során ezt nem sikerült alátámasztanunk. Még a csonkolt fehérjékkel számolva is 90 kDa méretű lenne egy trimer molekula, azonban a HOAP és a HP1 fehérjék által alkotott komplexek 66 és 40 kDa között mozognak (21-30 frakciók). Ha a molekulák alakjától eltekintünk, ebbe a mérettartományba a HOAP-HP1 és a HP1-HP1 dimerek tartoznak. Ez nem erősíti meg Badugu és munkatársai által leírt 1:2 HOAP-HP1 sztöchiometriát, igaz ők a HOAP prolinban gazdag C-terminálisát tették felelőssé a HP1-gyel történő kölcsönhatásért, ami esetünkben nincs jelen.

Mivel a Ver és a DTL dimer egyértelmú sztöchiometriával rendelkezik, valamint a fehérjék és kölcsönhatásuk is stabilnak bizonyult, az oldhatósági problémák ellenére is egyszerúbben vizsgálhatóak, mint a HOAP, HP1 és HipHop fehérjékből álló alkomplex. Ezért elkészítettem a csak a Ver és a DTL fehérjét termelő bicisztronos plazmidot. A két fehérje koexpressziója kis mértékben fokozta oldhatóságukat (18. ábra), ami elegendőnek bizonyult a heparin-sepharose oszlopon való tisztításhoz (22. ábra, A panel). A vártnak megfelelően (21. ábra), az alacsony só koncentrációnál 
gyújtött fehérjék a gélszűrés során is heterodimert képeztek és 45 kDa körüli mérettartománynak megfelelő frakciókban hagyták el az oszlopot (22. ábra, B panel).

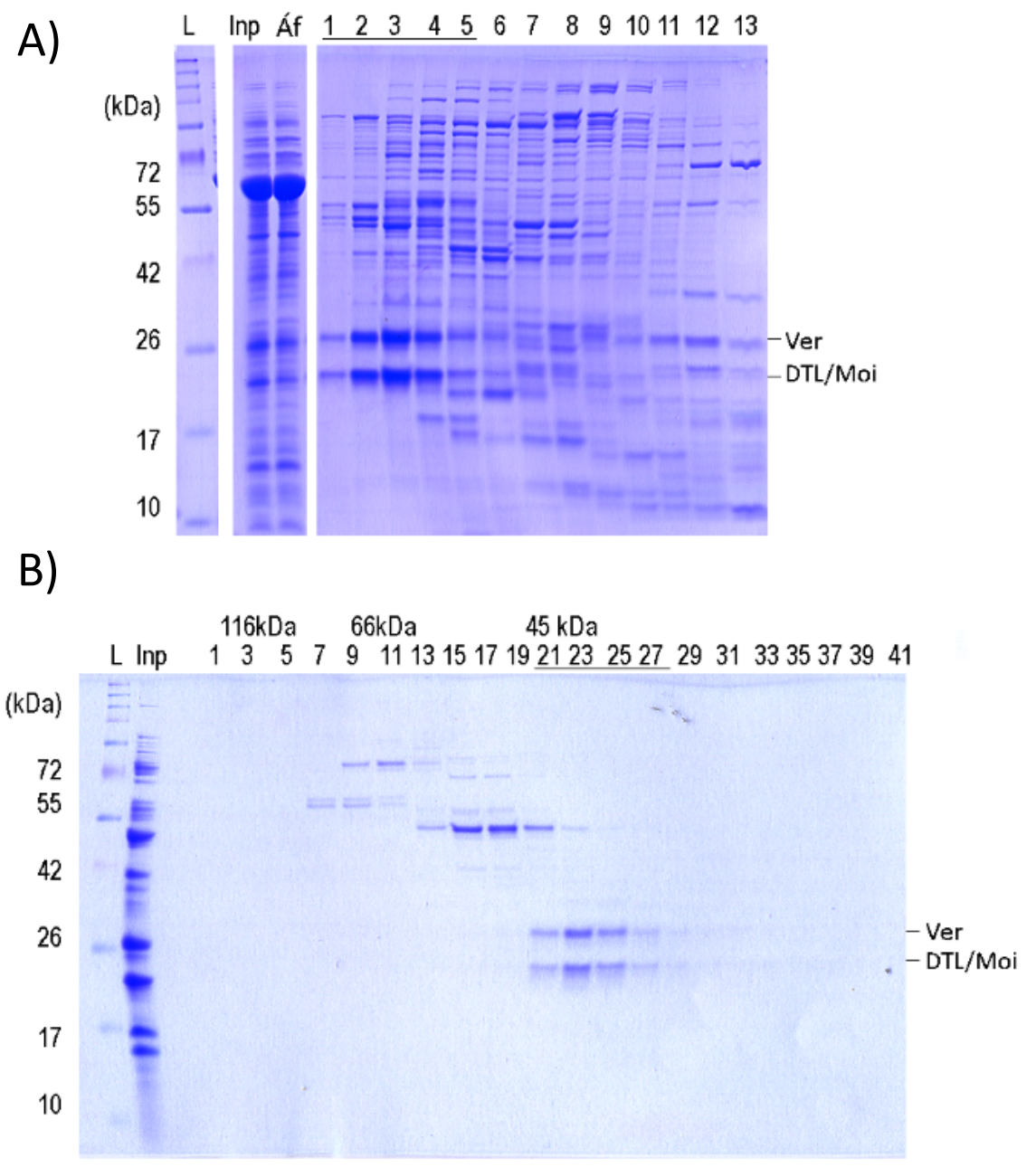

\section{2. ábra: A Ver és a DTL stabil heterodimert alkotnak.}

A Ver-DTL heterodimer tisztítása a korábban leírtaknak megfelelően történt, először heparin-sepharose oszlopon, majd gélszúréssel, melyek során gyűjtött frakciókat poliakrilamid gélen elemeztük. (A) A Ver és a DTL fehérjék együtt tisztíthatóak heparin-sepharose oszlopon (1-5. frakciók) és (B) gélszürés során stabil komplexet alkotnak (21-27. frakciók).

A frakciókat poliakrilamid gélen futtattam és elemeztem. L: molekulatömeg marker (létra); Inp: input, Áf: átfolyó; a számok a gyújtött frakciókat jelölik.

4.5 A D. yakuba Ver és a D. melanogaster DTL hibrid komplexet formálnak

A Ver és a DTL gyors evolúciót mutató fehérjék, és mivel funkciójuk az egész kromoszóma integritását érinti, ezért szerepük lehet a fajképzésben. A reprodukciós korlátként való múködéshez már közeli 
rokon fajokból származó fehérjék interakciójának hiánya is szükségszerűen megzavarhatja a telomer védelmében betöltött funkciókat. Ennek vizsgálatára, a viszonylag közeli rokon Drosophila yakuba Ver kódoló régióját felhasználva olyan bicisztronos plazmidot készítettem, mely a $D$. yakuba Ver ortológja mellett a D. melanogaster DTL fehérjét fejezi ki. A Ver ortológok 83\%-ban egyeznek, meg míg a $D$. yakuba és $D$. melanogaster DTL 89\%-ban hasonlítanak aminosav szekvencia szinten. A fehérjék kölcsönhatásának hiánya megerősítené hipotézisünket, mely szerint a fehérjék evolúciós változása csökkenti a hibridek életképességét.

A D. melanogaster Ver-DTL dimerrel megegyező módon termeltettem a fehérjéket, és mert elegendő oldható fehérje termelődött, heparin-sepharose oszlopon tisztítottam. A $D$. yakuba Ver és a $D$. melanogaster DTL azonos frakciókban eluálódtak, alacsony sókoncentráció mellett (23. ábra, A panel). A hibrid komplex létrejöttét gélszűréssel is megerősítettük, mely során 45 kDa körül azonosítottuk a hibrid dimert (23. ábra, B panel).

A)

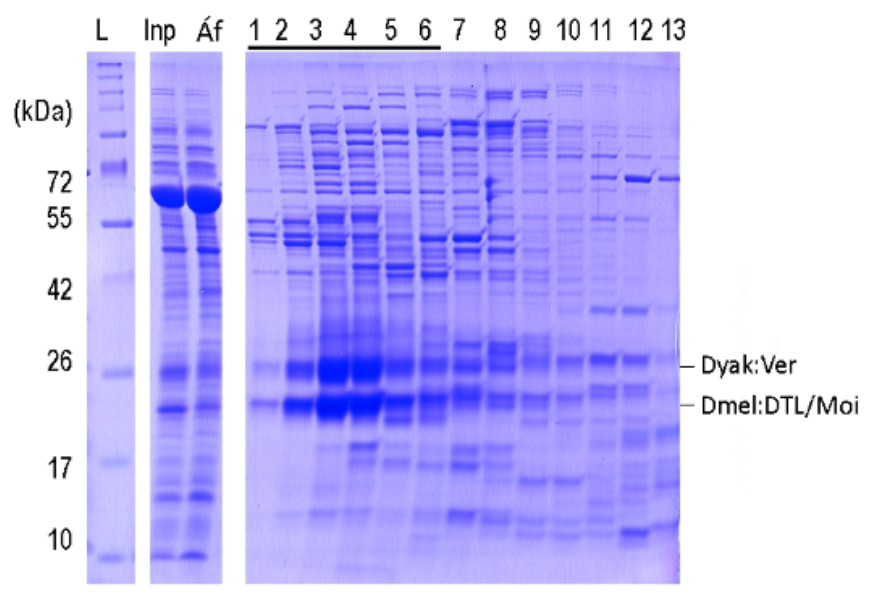

B)

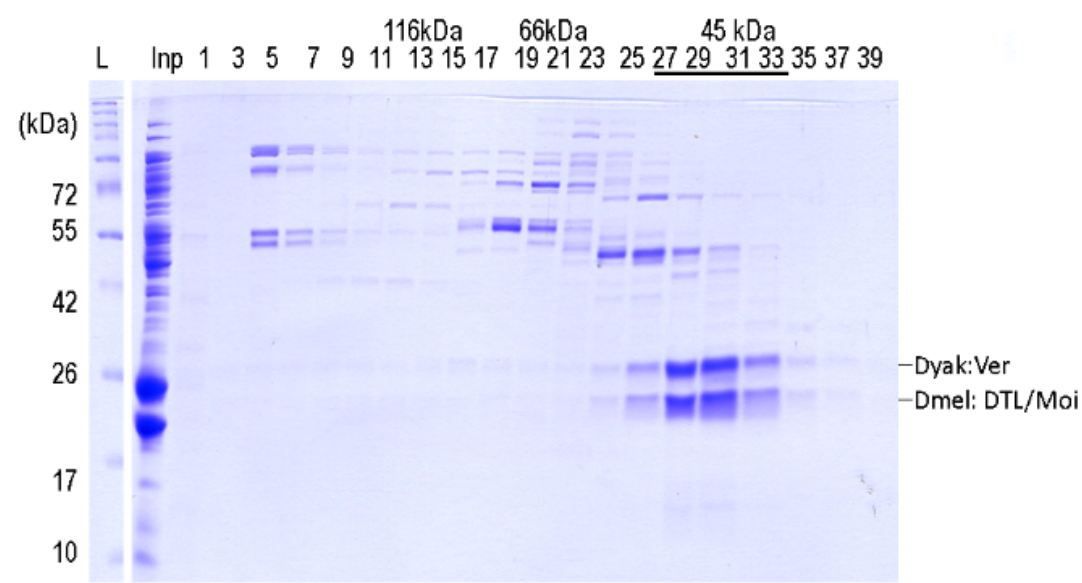

23. ábra: A $D$. yakuba Ver stabil komplexet alkot a $D$. melanogaster DTL fehérjével

A $D$. yakuba Ver és $D$. melanogaster DTL heterodimer tisztítása a korábban leírtaknak megfelelően történt, először heparin-sepharose oszlopon, majd gélszűréssel, melyek során gyüjtött frakciókat poliakrilamid gélen

59. 
elemeztük. D. yakubából származó Ver fehérje szintén dimer komplexet képez DTL-lel, amely (A) heparinsepharose oszlopon (1-6. frakciók) és (B) gélszűrés esetén is stabil maradt (27-33. frakciók).

A frakciókat poliakrilamid gélen futtattam és elemeztem. L: molekulatömeg marker (létra); Inp: input, Áf: átfolyó; a számok a gyűjtött frakciókat jelölik

A D. yakuba Ver és $D$. melanogaster DTL közti interakció jelenlétét más módszerrel is megerősítettük; haemagglutinin (HA) jelölt DTL fehérjével mindkét fajból származó Ver proteint sikerült tisztítani immunaffinitás kromatográfiával (8. függelék). Egy további eljárás, a far-western blot technika - mely lényegében a western blot fehérje-fehérje interakciók kimutatására használt variációja - nem bizonyult alkalmasnak a Ver-DTL kölcsönhatásnak a vizsgálatára (9. függelék).

\subsection{DNS-kötés vizsgálatok}

A Ver-DTL dimer feltehetően az egyes-szálú DNS-kötésért felel, azonban a komplex DNS-kötő képességét részleteiben még nem vizsgálták. A $D$. melanogaster és a hibrid Ver-DTL heterodimerek funkciójának összehasonlítása újabb lehetőség a terminin fajképzésben betöltött szerepének vizsgálatára. A hibrid komplex esetén tapasztalt esetleges funkcióvesztés ugyanis arra utalna, hogy a terminin fehérjék gyors evolúciós változása szerepet játszhat a fajok közti izolációban.

Ezért a heterodimerek egyes- és kettős-szálú DNS-kötő képességét vizsgáltuk. Ehhez mágneses gyöngyökre kötöttem 80 nukleotid hosszú egyes-szálú, kettős-szálú és 3' túlnyúló végú oligonukleotidokat és vizsgáltam, hogy melyik DNS féleséggel borított gyöngy képes több heterodimert megkötni. A Ver-DTL komplex a vártnak megfelelően nagyobb affinitással kötődött az egyes-szálú DNS-hez, mint a kettős-szálúhoz (24. ábra). A hibrid komplexszel végzett kísérletek során hasonló eredményt kapunk (24. ábra).

60. 
A) Dmel/Ner-Dmel/DTL

Dyak/Ver-Dmel/DTL

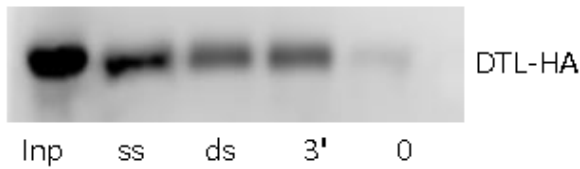

B)

B) $1,2 \quad \ln p \quad s s \quad d s \quad 3^{\prime} \quad 0$
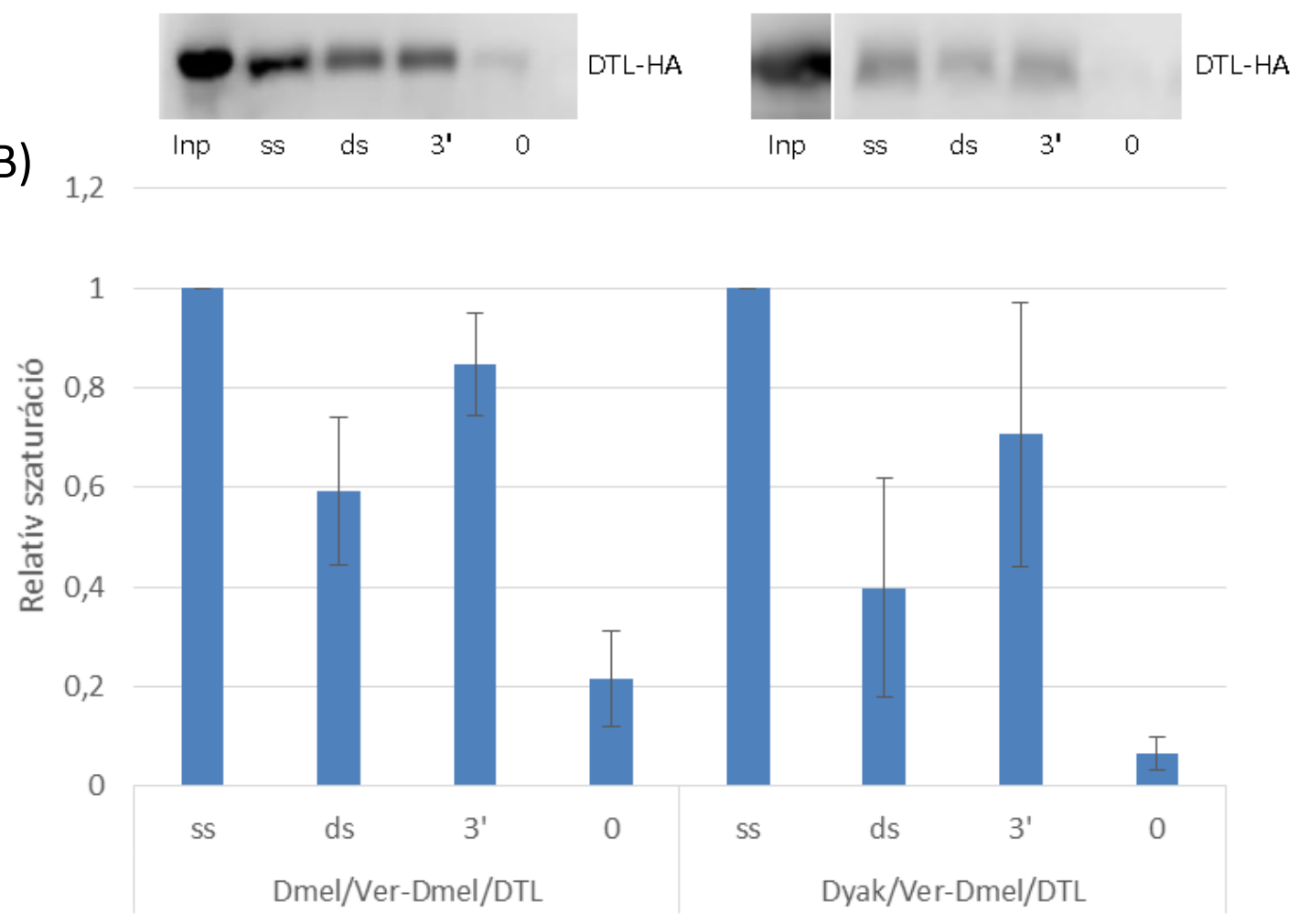

24. ábra: DNS affinitás mátrixhoz való kötődésük alapján $D$. melanogaster Ver-DTL heterodimer és $D$.yakubaD.melanogaster hibrid dimer is köti az egyes és kettős-szálú DNS-t.

(A) Western blot, ami a mágneses gyöngyökről eluálódott DTL-t mutatja. Az egyes-szálú DNS-sel borított gyöngyökről származó mintáknál kaptuk a legerősebb jelet. (B) Három kísérletből származó western blotokat pixel intenzitás alapján kiértékelve láthatjuk, hogy a Ver-DTL heterodimer az egyes-szálú DNS-t nagyobb affinitással köti. ss: egyes-szálú DNS, ds: kettős-szálú DNS, 3’: 3’ túlnyúló végű DNS, 0: gyöngyök DNS nélkül, Inp: input. A hibasávok a szórást ábrázolják 3 kísérlet eredményeiből számolva.

Az Ver-DTL DNS-kötő képességét érzékenyebb technikával, bioréteg interferencián (BLI) alapuló mérésekkel is megvizsgáltuk. A módszerhez fényvezető szenzorokat alkalmazunk, melyeket lényegében apró átlátszó múanyag oszlopok. Ha az oszlopba felülről fényt vezetünk, akkor a fény egy része az oszlop alján visszaverődik és az oszlopon belül visszajut a detektorba. Amennyiben a szenzor végéhez (az oszlop aljára) bármilyen molekulát kötünk, a szenzor hossza megváltozik, így a visszaverődő fény fázisa a kötődő molekulák méretével azonos mértékben eltolódik. Az eltérő fázisban a detektorba érkező fotonok interferálnak, mely lehetővé teszi a fáziseltolódás mértékének meghatározását és így a szenzor hosszváltozásának mérését. Kísérletünk során DNS molekulákat kötünk a szenzor végének felszínére, melynek sikeressége esetén a kötött molekula méretével 
arányos fáziseltolódást érzékelünk (10-11. függelék). A DNS-sel borított szenzorhoz ezt követően hozzáadjuk a Ver-DTL dimert, melynek kötődése újabb fáziseltolódást okoz.

A leírt kísérleti elrendezésben fontos, hogy a Ver-DTL fehérje preparátum más DNS-kötő molekulát ne tartalmazzon. A Ver-DTL dimer tisztítása ezért Flag-affinitás kromatográfiával történt, Ver fehérje N-terminálisának Flag jelölését követően. A tisztítás sikeres volt, habár szennyeződésként jelentős mennyiségű dajkafehérjét (Oleispira antarctica 60 kDa chaperonin) azonosítottunk, mely fehérje az Arctic Express sejtek alacsony hőmérsékleten való növekedéséért felelős (25. ábra). A dajkafehérjék nem DNS-kötő fehérjék, így méréseinket nem befolyásolják.

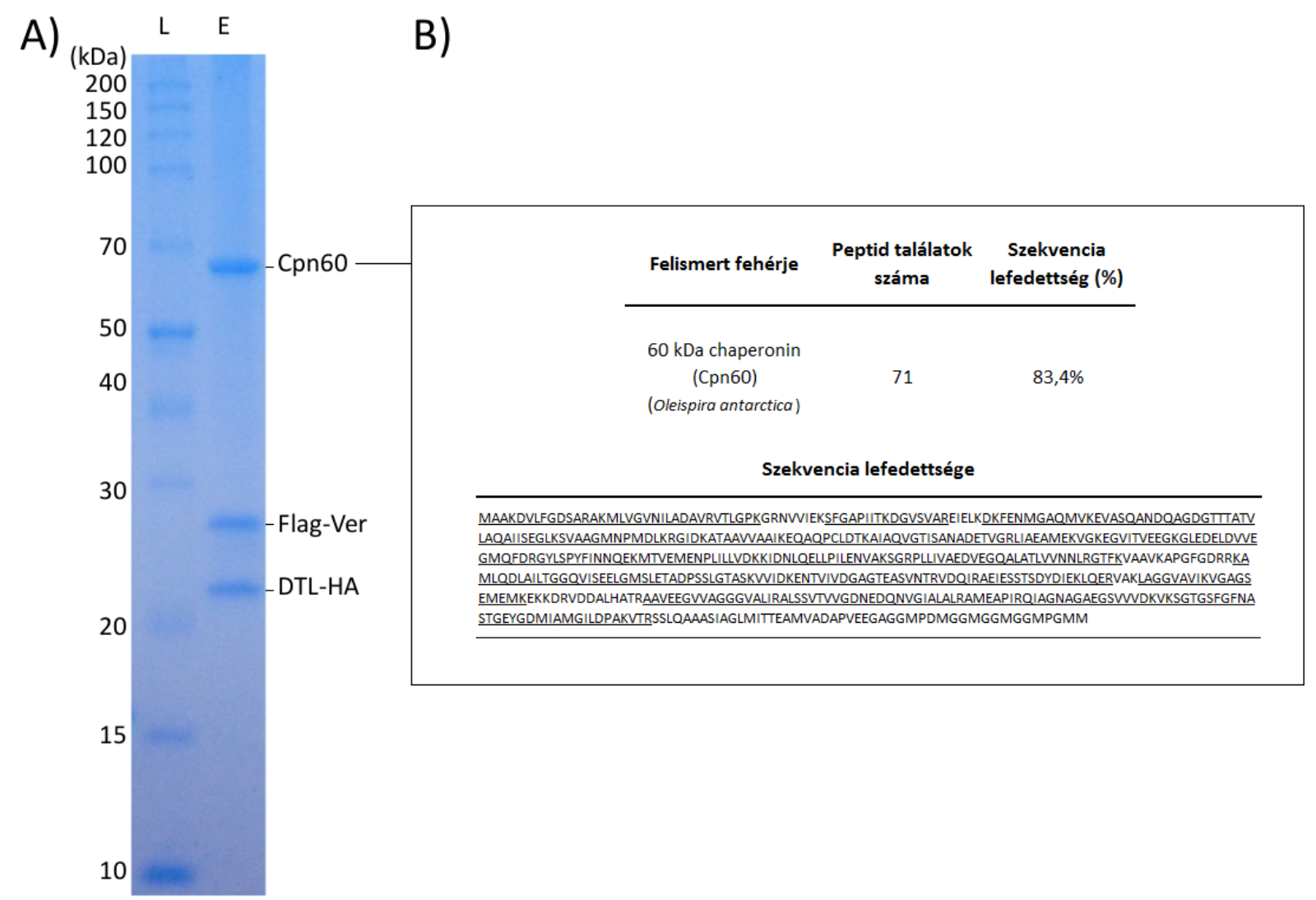

25. ábra: Flag immunaffinitás kromatográfiával megfelelö tisztaságú Ver-DTL dimer nyerhető BLI mérésekhez (A) Poliakrilamid gélen látható, hogy Flag immunaffinitás kromatográfia során a Ver és a DTL fehérjék mellett a $60 \mathrm{kDa}$ chaperonin is tisztult (E). (B) A dajkafehérjét tömegspektrometriával azonosítottuk.

L: molekulatömeg marker (létra); E: eluátum

A bioréteg interferencia vizsgálatok során korábbi kísérletekben használt biotinilált egyes-szálú, kettős-szálú és 3' túlnyúló végű DNS molekulákat használtam. A kontroll esetében a szenzor végére nem kötöttünk DNS-t. A DNS-fehérje kölcsönhatásokat a sikeres szenzor előkészítés után vizsgáltuk (10-11. függelékek). A korábbi kísérleteinkkel megegyező eredményeket kaptunk, mely szerint a VerDTL dimer affinitása az egyes-szálú DNS-hez a legnagyobb (26. ábra). A kötődés után a szenzorokat 
visszahelyeztük az alapvonal felvételére használt pufferbe, így a fehérjéink DNS-ről való disszociációját is megfigyelhettük.

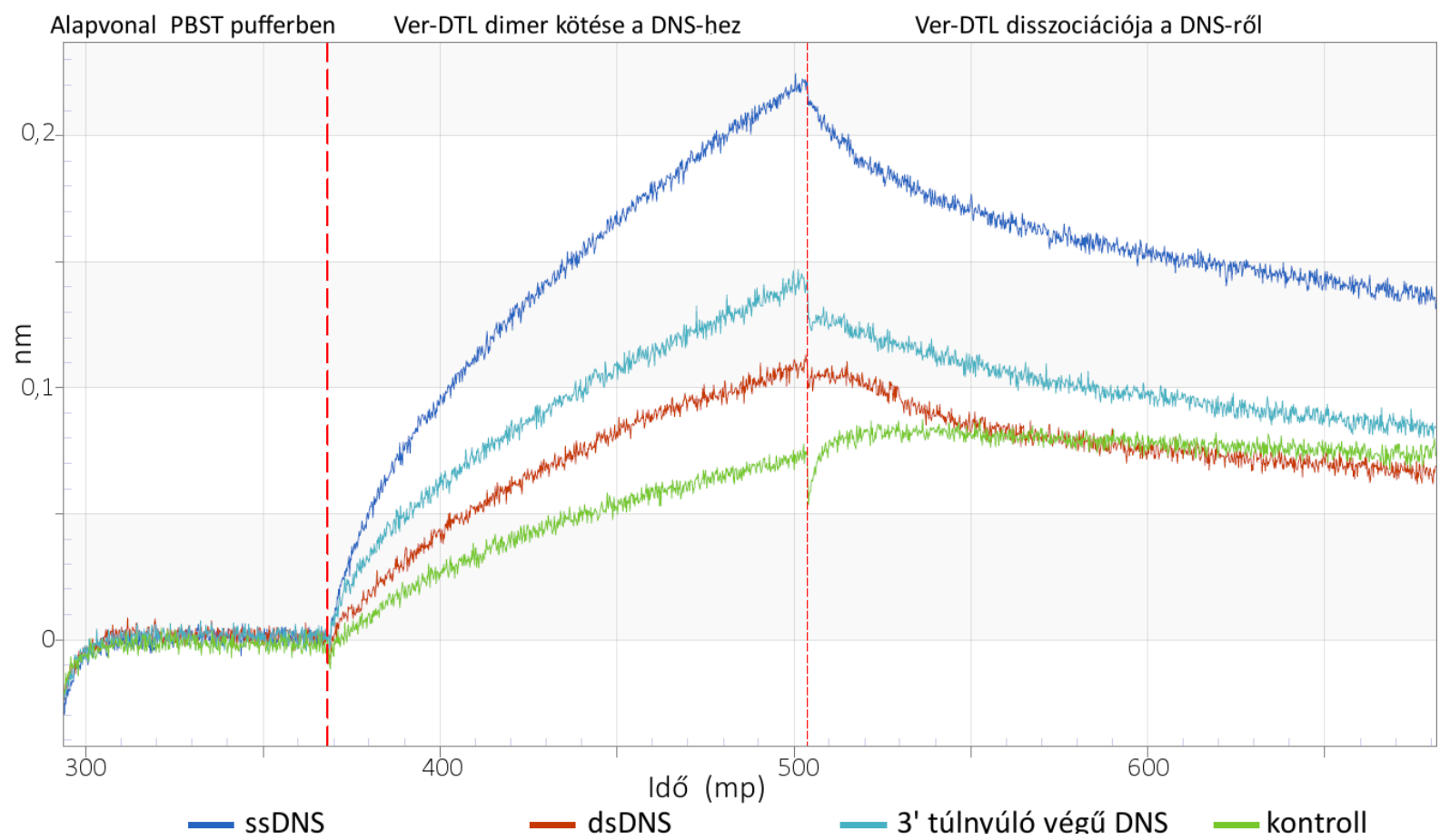

26. ábra: A Ver-DTL dimer eltérő affinitással köti az egyes-szálú, a kettős-szálú és a 3' túlnyúló végű DNS-t.

A fehérjék interakciója a szenzoron lévő DNS-sel a méréshez használt fény fázisának eltolódását eredményezi. A DNS-hez kötődő fehérjék mennyiségével a fáziseltolódás $(\mathrm{nm})$ egyenesen arányos. Tehát a legerősebb kötődést az egyes-szálú DNS (sötét kék) esetében, míg a leggyengébbet a kettős-szálú DNS (piros) esetében tapasztaljuk. A DNS-t nem tartalmazó kontroll (zöld) esetében a kötési lépésnél szintén látunk változást a jel erősségében, viszont mert a disszociáció lépésben a kontroll értéke stabil marad, ez feltehetően nem specifikus kötődést jelent. (ssDNS: egyes-szálú DNS, dsDNS: kettős-szálú DNS)

Hasonló kísérleti elrendezést használva megvizsgáltuk a Ver-DTL dimer és az egyes-szálú DNS közötti kötés kinetikáját (27. ábra). Ehhez a kísérlethez hat szenzorra egyes-szálú DNS-t kötöttünk, illetve egy DNS nélküli kontroll szenzort használtunk. Ver-DTL fehérjéből hígítási sort készítettünk (2x, 4x, 8x, $16 x$, 32x) és a komplexet különböző koncentrációban tartalmazó oldatokban mértük az egyes-szálú DNS kötés mértékét. A felvett görbék alapján és a koncentrációk ismertében ki tudjuk számolni az egyes-szálú DNS és Ver-DTL heterodimer interakció disszociációs állandóját. Amennyiben a fehérje komplex egy DNS kötő felszínnel rendelkezik, a kapott eredmények klasszikus telítési görbét rajzolnának ki, azaz a kezdeti emelkedést követően a görbe meredeksége nullára csökkenne. Ezzel szemben a kötődés a görbék alapján kétfázisú, egy gyors kötődési fázist egy lassabb követ. Az 1x minta esetén a gyorsabb kinetikájú felszín telítődésére utal a 0,1 nm-nél látható meredekség csökkenés (27. ábra), azonban a helyett, hogy a görbe meredeksége tovább csökkenne, míg eléri a 
telített állapotot (vízszintest), azt tapasztaljuk, hogy további molekulák kötnek a DNS-hez és a görbe meredeksége nem változik lényegesen. A lassabb kinetikájú kötés feltehetően egy másik DNS kötő felszín jelenléte eredményezi.

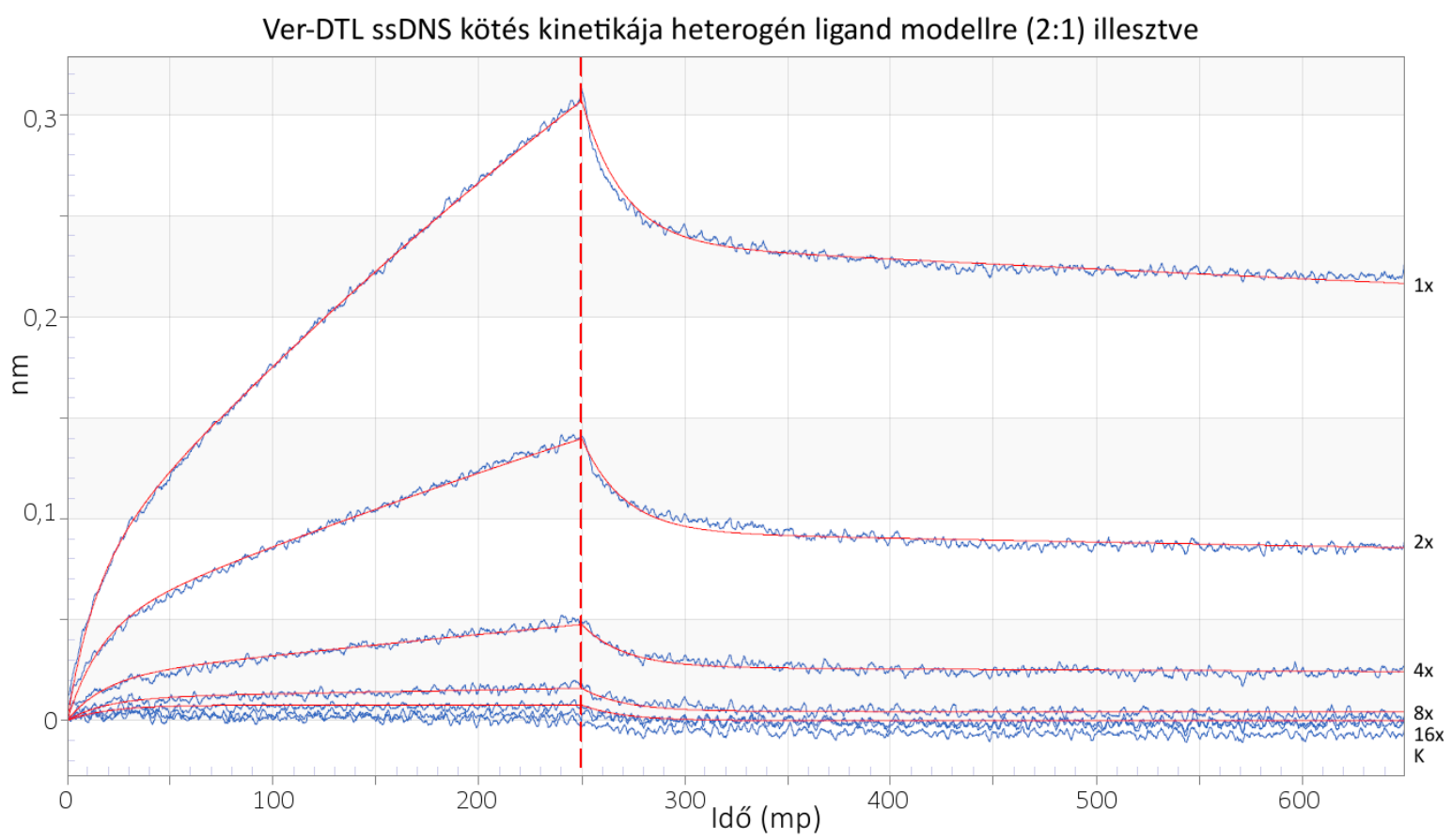

27. ábra: A Ver-DTL dimer egyes-szálú DNS-hez való kötési görbéi, heterogén ligand (2:1) modellre illesztve. A Ver-DTL dimer kötési görbéi nem klasszikus telítődési görbét mutatnak. Egy gyors kötési fázis után egy lassabbat figyelhetünk meg, ami arra utal, hogy a Ver-DTL dimer két DNS-kötő felszínnel rendelkezik. (kék görbe: mért értékek, vörös görbe: illesztett görbe)

A Ver-DTL heterodimer ez alapján két DNS-kötő domént is tartalmaz. A disszociációs állandó kiszámolásához ezért a kettős telítési görbék esetén használható matematikai képletet, a heterogén ligand modellt alkalmaztuk. A görbét leíró egyenletünk jól illeszkedett az adatsorunkra $\left(R^{2}=0,9994\right)$ mely alapján a rendszer szoftverét felhasználva meg tudtuk állapítani mindkét felszínhez tartozó disszociációs állandót. Az erősebb kötődésért feltehetően a Ver Ob-fold doménje felel $\left(K_{d}=1.29 \mathrm{E}-07\right.$ M), míg a gyengébbért a DTL DNS-kötő doménje $\left(K_{d}=1.57 E-06 M\right)$. A DTL-ről leucinban gazdag szekvenciája miatt korábban is feltételezték, hogy DNS-kötő fehérje [Komonyi et al. 2009]. Kísérleteink megerősítik ezt a feltételezést és adataink arra utalnak, hogy a DTL önmagában (9. függelék) és a Ver proteinnel alkotott dimerként is képes kötni a DNS-t. 


\section{Diszkusszió}

Dolgozatomban a Drosophila telomer fenntartásában résztvevő terminin komplex gyorsan evolválódó fehérjéivel foglalkoztam, bioinformatikai, molekuláris biológiai és biokémiai megközelítéseket alkalmazva. Az a rendkívül érdekes jelenség inspirálta kutatásomat, hogy az egyébként konzervált fehérjék funkcióját Drosophilában gyorsan változó fehérjék vették át, ennek ellenére a telomer múködése mégsem sérült. A fehérjék gyors evolúciójának és interakcióiknak a tanulmányozásán kívül, vizsgáltam a fehérjék fajképzésben betöltött lehetséges szerepét is.

\subsection{A terminin fehérjék gyorsan változó doménjeiken át alakítanak ki kölcsönhatásokat}

A terminin fehérjék evolúciójának jobb megértése érdekében 12 annotált és 9 még nem annotált Drosophila genomban végeztem kereséseket, és azonosítottam a vizsgált fehérjéket és homológjaikat kódoló DNS szakaszokat. A szekvenciák elemzéséből kiderült, hogy a terminin fehérjék közül a HP1 konzervált, míg a DTL, a Ver, a HOAP, és a HipHop fehérjék változékonyak. Az irodalmi adatok és az in silico eredményeink összevetése alapján a fehérjék közötti kölcsönhatások, azok gyorsan változó doménjein keresztül valósulnak meg. Ez a felismerés összhangban áll hipotézisünkkel a fehérjék fajképzésben betöltött szerepéről, hiszen ha a fehérjék interakciós felszínei gyorsan változnak, akkor az intenzív koevolúciót feltételez a terminin tagok között, így a koevolúció biztosítja a funkció fennmaradását. A gyors evolúció miatt ugyanakkor már közeli rokon fajok esetében is lehet olyan jelentős a terminin fehérjék interakciós felszínei közötti eltérés, hogy nem képesek kölcsönhatásba lépni egymással. Ez pedig hibridben veszélyezteti a terminin komplex múködését, ami a DNS hibajavítás aktiválásához, kromoszóma fúziókhoz, a sejt pusztulásához és posztzigotikus izolációhoz vezethet. Azonban egy gyorsan változó domén is tartalmazhat konzervált felszíneket, és ha az interakció ezeken a felszíneken valósul meg, akkor a fajképzésben betöltött szerep megkérdőjelezhető.

Mivel a terminin fehérjék többségének nem ismerjük a térszerkezetét, in silico nem állt módunkban közvetlenül vizsgálni az interakciós felszíneket. A gyors evolúciójú fehérjék közül egyedül a Verrochio protein esetében tudtunk közel megbízható térszerkezeti modellt létrehozni, melyhez Ver Ob-fold fehérjékkel mutatott homológiáját használtuk [Raffa et al. 2010]. Predikcióink szerint a $D$. yakuba és a $D$. grimshawi Ver fehérjéi, melyek aminosav szinten $86 \%$-ban, illetve 51\%-ban azonosak a $D$. melanogaster Ver fehérjével, szintén felvehetik az Ob-fold struktúrát. A modell alapján úgy gondoljuk, hogy a fehérje N-terminálisán található egy magi lokalizációs szignál. Megállapítottuk, hogy a szekvenciában elszórtan elhelyezkedő konzervált aminosavak a térszerkezet fontos szerkezeti

65. 
pozícióiban találhatóak. Ilyen módon, bár a Ver fehérje konzerváltsága aminosav szinten alacsony, a szerkezete mégsem változik lényegesen. Köszönhetően a konzervált szerkezetnek, a DNS kölcsönhatásban feltehetően részt vevő konzervált aminosavak minden modell esetében hasonló pozíciót vettek fel. Ez alapján úgy túnik, hogy a funkcionális szempontból fontos aminosavak mégsem evolválódnak gyorsan. Két további felszínt is kijelöltünk a molekulán, melyek a helyes térszerkezet kialakulása esetén hasonló konzervált interakciós felszínként múködhetnek, azonban annak kísérletes bizonyítása, hogy ezek valóban ilyen szerepet játszanak, még nem történt meg.

A Ver és a DTL fehérjék mind méretben, mind evolúciójuk sebességében és számolt másodlagos szerkezeti elemeik (alfa-hélixek és béta-redők száma) alapján is hasonlítanak egymásra, ezért a Ver esetében tapasztaltak a DTL esetében is érvényesek lehetnek, azaz a konzervált aminosavaknak a fehérje szerkezetének kialakításában lehet jelentős szerepe.

A HOAP és a HipHop fehérjékre ezek a megfigyeléseink csak korlátozott mértékben terjeszthetőek ki, mert szerkezetükben lényegesen eltérnek a Ver és a DTL fehérjékétől. Ezek interakciós doménjeire inkább alfa hélixek jellemzőek, továbbá kiterjedt nem rendezett doméneket hordoznak, melyek akár linker, akár interakciós funkciót is betölthetnek (4-5. függelékek).

\subsection{A terminin komplex két alkomplexből szerveződik}

A terminin komplex kialakulásának és biokémiai jellemzésének megvalósításához a komplex fehérjéit heterológ expressziós rendszerben termeltettem. A Ver és DTL fehérjék többsége „inclusion body”-ba került, mely nem oldható nagyrészt abnormális térszerkezetű fehérjék aggregátuma. A kapott eredmények összeegyeztethetőek az in silico adatokból levont következtetéseinkkel, miszerint a béta redőben gazdag Ver és DTL fehérjék helyes térszerkezetének kialakulása nehézkes lehet a baktériumban. A HOAP és a HP1 fehérjék önmagukban termeltetve is oldható formában szintetizálódnak, viszont a HipHop fehérje nagy mennyiségben történő expresszióját többszöri próbálkozás után sem sikerült megoldanunk.

A proteinek együtt termelése növelte a fehérjék oldhatóságát, ami valószínúleg a köztük kialakuló kölcsönhatásoknak köszönhető. A leglátványosabban a HOAP-HP1 koexpresszió növelte a fehérjék oldhatóságát 50\%-ról közel 100\%-ra, továbbá a Ver és a DTL koexpressziója esetén is nagyobb arányban oldható fehérjéket sikerült előállítanunk. Ezek az eredmények összeegyeztethetőek a korábban GST-pull down kapott adatokból [Gao et al. 2010, Raffa et al. 2009, Raffa et al. 2010], és egy HipHop nélkül is összeszerelődő komplex létezésére utalnak (16. ábra). Végül, az oldható formában előállított fehérjéket használva lehetőség adódott a terminin komplex in vitro vizsgálatára. 
Azonban, a terminin komplexet alkotó összes feltételezett fehérje együttes expressziójával sem tudtuk kimutatni a mind a négy vizsgált fehérjét tartalmazó holokomplex képződését. Helyette két alkomplexet azonosítottunk.

Annak, hogy a terminin holokomplex nem volt kimutatható a kísérletinkben, több oka is lehet. A komplex kialakulását elméletileg akadályozhatta a heparin-sepharose oszlopról történő elúció során használt sógradiens, azonban ez nem valószínű, mert a frakciók alacsony sókoncentráción (100 mM $\mathrm{NaCl})$ történő egyesítése után sem tapasztaltuk a holokomplex kialakulását. Amennyiben a komplex már a koexpresszió alatt sem jött létre, az magyarázza, hogy az oldhatósági tesztek során a HOAP és a HP1 jelenléte miért nem volt hatással Ver oldhatóságára. Szintén valószínútlen, bár nem kizárható, hogy a HipHop fehérje nagyobb koncentrációban szükséges a holokomplex létrejöttéhez. Egy másik, valószínúbb eshetőség az, hogy további interakciós partnerek hiányoznak a komplex kialakulásához. 2015-ben és 2016-ban írták le, hogy a Pendolino (Peo), illetve Separase (Sse) fehérjék kölcsönhatásba lépnek a terminin fehérjékkel, így ezek akár a komplex részeiként is funkcionálhatnak [Cenci et al. 2015, Cipressa et al. 2016]. Ezen kívül egyes adatok arra utalnak, hogy a Hmr és Lhr fehérjék is kölcsönhatást mutatnak a terminin fehérjékkel, melyek ugyancsak szerepet játszhatnak a holokomplex kialakításában [Thomae et al. 2013, Statyaki et al. 2014]. A genetikai kölcsönhatások alapján a HOAP központi szerepet tölt be a terminin fehérjék komplexszé szerveződésében [Raffa et al. 2011], ezért elképzelhető, hogy a kísérleti rendszerünkben megfigyelt C-terminális degradációja a holokomplexet kialakító interakció megszúnését eredményezte. Végül pedig a holokomplex kialakulásának hiánya azzal is magyarázható, hogy a teljes komplexet összetartó kölcsönhatások gyengék ahhoz, hogy a kísérleti rendszerünkben kimutathassuk létezésüket, és poszttranszlációs módosítások hiánya is okozhatja a terminin holokomplex formálódásának elmaradását.

Érdemes kiemelni, hogy a két alkomplex szerveződése összhangban áll a molekuláris funkciójukkal, azaz, hogy az őket alkotó fehérjék az egyes vagy a kettős-szálú DNS-javító mechanizmus gátlásában vesznek-e részt. A kettős-szálú hibajavítás gátlásáért felelős HOAP, HP1 és HipHop alkotja az egyik alkomplexet és az egyes-szálú hibajavítás gátlásáért felelős Ver és DTL a másikat. A HOAP, HP1 és HipHop alkomplex esetén nem sikerült egyértelmú sztöchiometriát megállapítanunk, melynek oka részben a HipHop alacsony koncentrációja és a másik két fehérje csonkolt formájának a jelenléte. A Ver és a DTL viszont egyértelmúen heterodimert alkotnak, és erősen kötődnek az egyes-szálú DNShez. 


\subsection{A Ver-DTL heterodimer és a fajképzés}

A Drosophila telomer fenntartásában részt vevő fehérjék evolúciós változékonysága összeegyeztethetetlennek tűnik fontos funkciójukkal. A fontos sejtfunkciók fenntartását általában erősen konzervált gének végzik, melyekben akár egyetlen mutáció is végzetes lehet a sejt számára. Drosophilában viszont a kromoszómák integritásának megőrzéséért felelős telomer fehérjék gyors evolúciót mutatnak. Ennek az ellentmondásnak többféle feloldása is lehetséges. Egyrészt elképzelhető, hogy a fehérjéknek a szerkezete és az interakciós felszínei konzerváltak és így képesek megbízhatóan ellátni a funkciójukat. Egy másik lehetőség az, hogy a fehérjék koevolválódnak. Ebben az esetben a gyors evolúció egyszerre kell, hogy megváltoztassa a fehérjék interakciós felszíneit. Ha a változások gyorsak, akkor már közeli rokon fajokból származó fehérjék felszínei is különbözhetnek annyira, hogy ne alakuljon ki közöttük kölcsönhatás és a telomer funkciója sérüljön. Így ezek a proteinek a kromoszómák védelmén kívül hozzájárulhatnak a fajok közti izolációhoz.

A terminin fehérjék közötti interakció hiányát kutatva létrehoztam egy olyan bicisztronos expressziós vektort, mely kifejezte a $D$. melanogaster DTL és a $D$. yakuba Ver fehérjéket. Az expresszált fehérjék stabil kölcsönhatást mutattak annak ellenére, hogy a Ver 17\%-ban, míg a DTL 11\%-ban tér el a $D$. yakuba ortológjától. Figyelembe véve, hogy a $D$. yakuba Ver és a $D$. melanogaster DTL hibrid komplexet alkotnak, feltételezhetjük, hogy a köztük lévő interakció konzervált felszínen keresztül valósul meg. A hidrofób aminosavak egy fehérje felszínén gyakran interakciós felszínek részeit képezik, de előfordulhat az is, hogy a modell hibájából fakadóan került rossz helyre az adott aminosav. Ha megbízhatónak ítéljük modellünket és hidrofób, ugyanakkor konzervált aminosavakat keresünk, potenciális interakciós felszíneket azonosíthatunk. A Ver esetében ez három pozíciót jelent (28. ábra).

Az első konzervált és hidrofób aminosav a magi lokalizációs szignálon figyelhető meg (28. ábra, fekete körök), ami feltehetően az importin fehérjék kötéséhez szükséges. A második régió a rosszul prediktálható, változékony hélixeknél látható (28. ábra, sárga körök), mely esetben több hidrofób aminosav is látható a felszínen. A harmadik régió alkotja a legnagyobb konzervált felszínt a molekulán (28. ábra, A-B panelek, szaggatott körvonal). Ezt a területet az Ob-fold és az azt stabilizáló alfa hélix közös felszíne határozza meg, így ennek a felszínnek a kialakulása több távoli aminosav megfelelő pozícionálásán múlik. Figyelembe véve, hogy Ver helyes térszerkezetét már a baktériumban való termeltetés során sem vette fel, feltételezhetjük, hogy dajkafehérjék hiányában alig alakul ki a megfelelő térszerkezetű aktív protein. Ez megmagyarázná azt a jelenséget, hogy az egyéb módszerekkel kimutatott stabil Ver és DTL dimer miért nem vizsgálható a fehérjék denaturációjával járó far-western blot kísérletek segítségével (9. függelék). Ezeket a megfigyeléseket összegezve azt 68. 
feltételezzük, hogy a Ver-DTL interakció az Stn1-ten1 modellen tapasztaltakhoz hasonló, azaz a DTL fehérje az Ob-fold és az azt stabilizáló hélix által alkotott felszínen lép kölcsönhatásba a Ver proteinnel. Ez esetben tehát a fehérjék közti kölcsönhatás inkább köszönhető a konzervált szerkezetnek és egy konzervált interakciós felszínnek, mint az interakciós felszínek koevolúciójának.

A)

B)
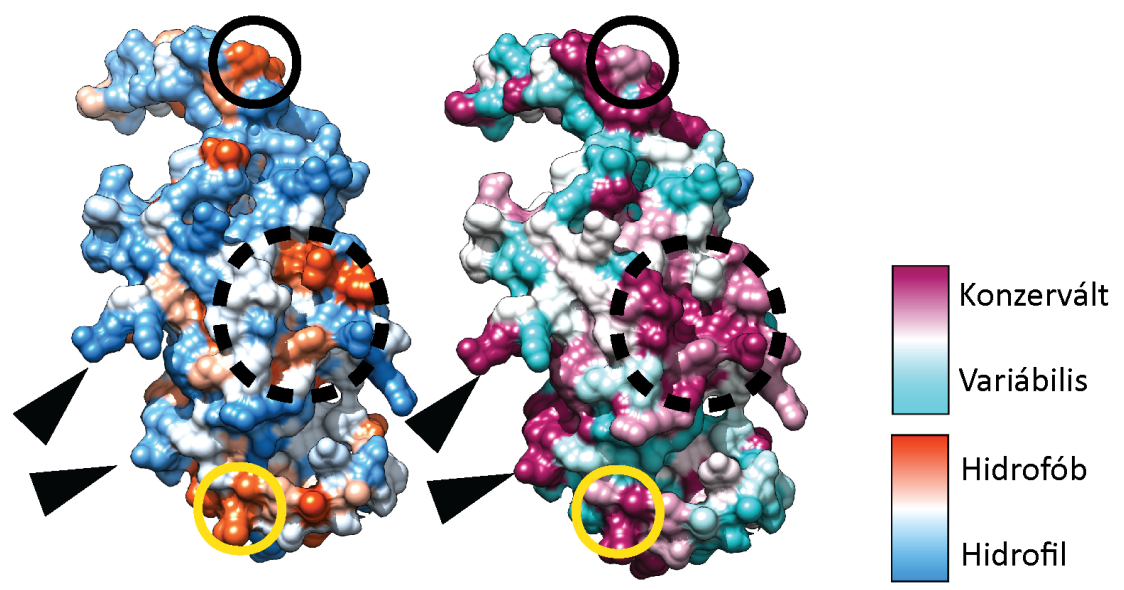

C)

D)
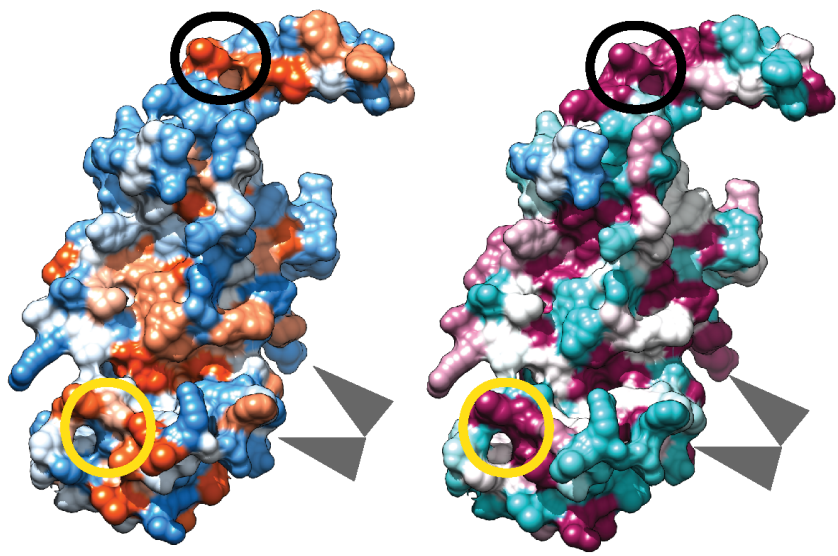

Konzervált hidrofób régió

Legnagyobb

konzervált felület

DNS-kötő árok

\section{8. ábra: Lehetséges fehérje-fehérje interakciós felszínek a Ver fehérjén}

A felszínek összehasonlítása hidrofobicitás $(A, C)$ és konzerváltság $(B, D)$ szempontjából történt. $A z$ „ $A$ ” és „ $B$ ” a molekula elölnézeti képe, míg " $C$ ” és „ $\mathrm{D}$ ” hátulnézetben mutatja a Ver térkitöltő modelljét. A kék-piros színátmenet megfeleltethető a fehérje hidrofobicitásának, a cián-lila színátmenet az adott aminosav konzerváltsági értékeivel arányos. A konzervált hidrofób felszíneket körök jelzik. A feltételezett DNS kötő felszínt nyílhegyek mutatják.

Hasonló jelenséget láthatunk a Ver feltételezett DNS-kötő árkánál, ahol a konzervált interakciós felszínt kialakító aminosavak abban az esetben pozícionálódnak megfelelően, ha a helyes 
térszerkezet kialakult. Ennek értelmében a hibrid Ver-DTL dimer DNS-kötő funkciója sem sérül, amit kísérleteinkkel is alátámasztottunk.

A terminin fehérjék fajok keletkezésében játszott szerepének vizsgálatára különböző fajokból származó terminin fehérjék közötti kölcsönhatás változását kerestük. Azt tapasztaltuk, hogy a $D$. melanogaster DTL kölcsönhatott a $D$. yakuba fajból származó Ver fehérjével, ami arra utal, hogy a gyors evolúció nincs hatással a fehérjék közti interakcióra, így nem járul hozzá a fajok közti izolációhoz. Ez nem jelenti azt, hogy hipotézisünket, mely szerint a terminin fehérjék részt vesznek a fajképzésben, szükségszerűen el kell vetnünk. Az interakció megszűnése alátámasztaná a fajképzésben betöltött szerepet, de annak megmaradása sem zárja ki ennek lehetőségét. Elképzelhető, hogy a kölcsönhatás megmarad, ám a magasabb szinten szerveződő komplex funkciója sérül. Sőt a Hmr és az $L h r$ speciációs gének példájából tudjuk, hogy bizonyos esetekben a gyorsan evolválódó fehérjék kölcsönhatása szükséges a speciációs korlátként való múködésükhöz [Thomae et al. 2013, Fukagawa 2013]. A Hmr és Lhr fehérjék kölcsönhatnak egymással és centromer kialakulásához mind a két fehérje szükséges. $D$. melanogaster és D. simulans hibridben a fehérjék feltehetően magas expressziós szintet mutatnak, melynek következménye, hogy a Hmr és az Lhr fehérjék a centromereken kívüli heterokromatikus régiókban is megjelennek. Ez oda vezet, hogy több centromer is kialakul a kromoszómán, ami meggátolja a sikeres sejtosztódást.

\subsection{A Ver-DTL dimer szerepe a DNS hibajavítás gátlásában}

Az emlős TPP1-Pot1 fehérjék az emlős telomeren az egyes-szálú DNS-törések hibajavításnak gátlásáért felelnek. A Pot1 a Ver-hez hasonlóan Ob-fold fehérje, míg TPP1 adapter szerepet tölt be a Pot1 és a telomer védelmét szolgáló egyéb fehérjék között. Raffa és munkatársai többször is hivatkoznak nem publikált kísérleteikre, melyek alapján a Ver az egyes-szálú DNS-kötésért felelős Obfold fehérje [Raffa et al. 2010, 2011]. A Ver-DTL komplex ezért hasonlóan múködhet a TPP1-Pot1 fehérjékhez, viszont esetünkben a DTL nem csupán adapter funkcióval rendelkezik, hanem DNS-kötő aktivitással is. Ez az aktivitás önmagában azonban nem lehet elegendő a telomer védelméhez, hiszen akár a Ver, akár a DTL fehérje hiánya kromoszóma fúziót okoz [Raffa et al. 2011].

Komonyi és munkatársai genetikai kölcsönhatásokat vizsgáltak a DTL és a DNS-javító mechanizmusok génjei között, és megállapították, hogy a DTL nem az ATM, hanem az ATR hibajavító útvonalon keresztül fejti ki hatását [Komonyi et al. 2009]. Az ATM (tefu/atm) mutánsokkal ellentétben, az ATR (mei41/atr) mutánsok nem eredményeznek kromoszóma fúziókat Drosophilában [Oikemus et al. 2006]. Ezért feltételezhetjük, hogy a terminin komplex kialakulásában az ATR fehérjének nincs 
szerepe, viszont a terminin kialakulása gátolja az ATR útvonal telomeren történő aktiválódását. Ezt támasztja alá, hogy a DTL mutánsokban a kromoszóma fúziók gyakoriak, míg a DTL és ATR (mei41/atr) kettős mutánsokban a kromoszóma fúziók száma csökkent [Komonyi et al. 2009]. Eredményeink szerint a DTL és a Ver heterodimerként funkcionál és molekuláris szerepe az egyesszálú DNS kötése. Ez magyarázza, hogy a dtl-atr kettős mutánsok miért mutatnak kevesebb kromoszóma fúziót, amit a korábbi adatok alapján még nem lehetett értelmezni. Az eredmények alapján ezt a jelenséget egyszerúen megmagyarázhatjuk (29. ábra).

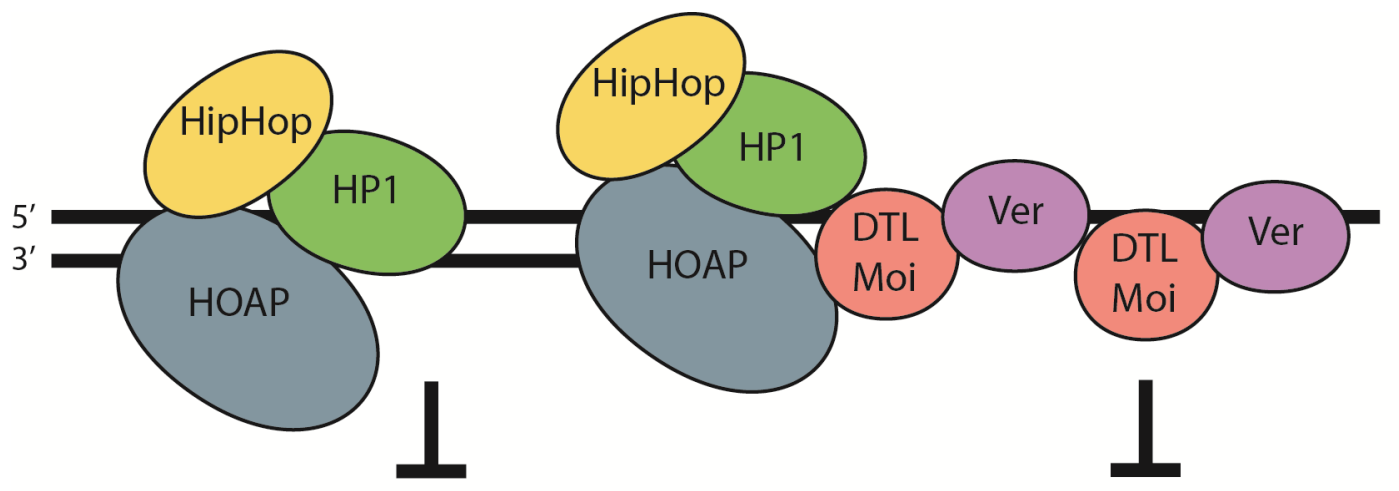

ATM útvonal

ATR útvonal

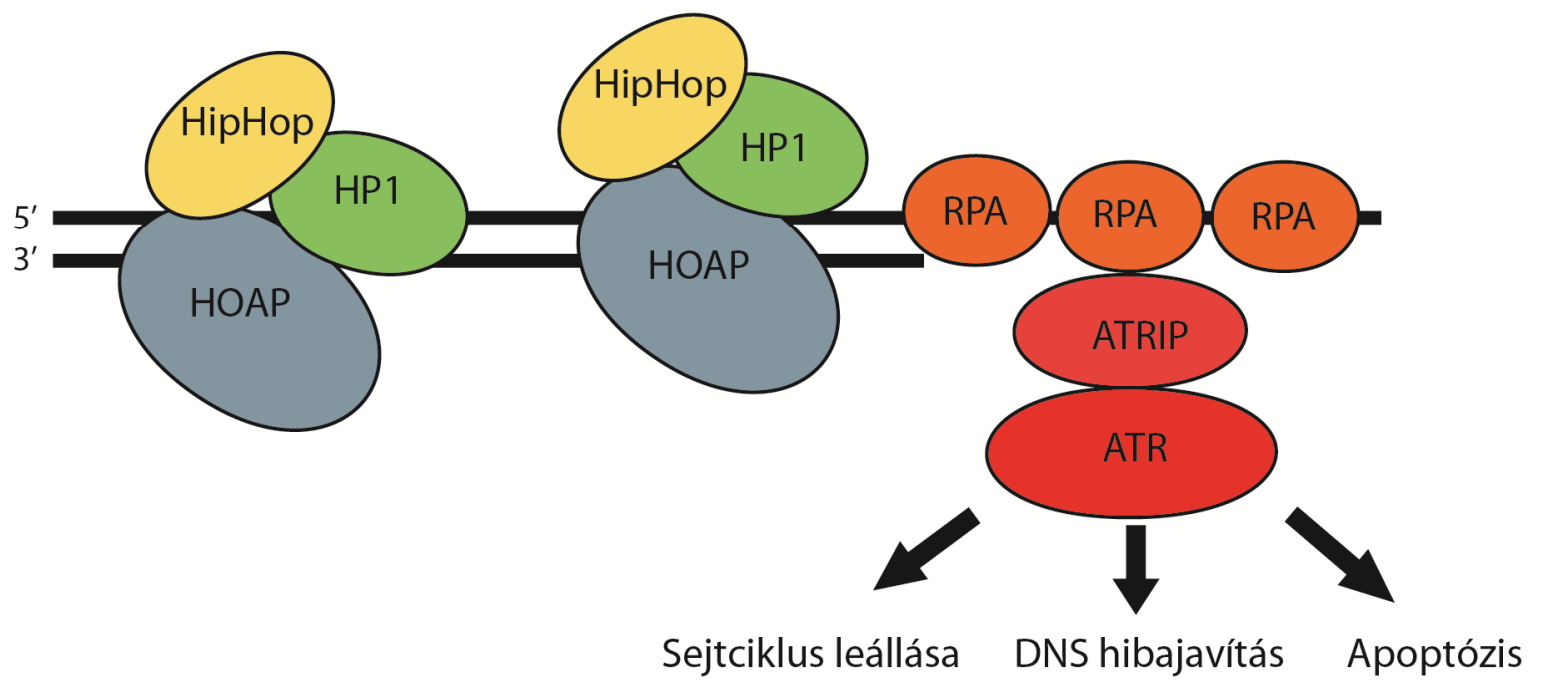

\section{9. ábra: A DTL-Ver dimer gátolja az ATR szignalizációs útvonalakat}

Ver vagy DTL hiányában a telomer DNS 3' túlnyúló vége szabaddá válik és RPA fehérjék kötődnek hozzá, melyek elindítják az ATR szignalizációt.

Modellünkben a DTL-Ver heterodimer a kromoszómák végén található egyes-szálú DNS-t kötik, lokalizációjukat a HOAP fehérje segíti [Raffa et al. 2011]. Akár a DTL, akár a Ver fehérjét kódoló gén mutációja esetén, a kromoszóma végeken található egyes-szálú DNS szabaddá válik és az általánosan 
egyes-szálú DNS-t kötő RPA fehérjék halmozódnak fel rajta [Fanning et al. 2006]. Ezt követően az RPA fehérjék ATRIP és ATR fehérjéket toboroznak a kromoszóma végekhez, aminek eredményeként az ATR DNS hibajavító útvonal aktiválódik [Zou és Elledge 2003]. Az atr mutációja esetén viszont az útvonal aktiválódása elmarad, ez pedig megmagyarázza, hogy miért látunk kevesebb kromoszóma fúziót a dtl-atr kettős mutánsokban [Komonyi et al. 2009].

\subsection{Gyors evolúciójú fehérjék a fajképzésen túl}

Kutatásom a terminin komplex alaposabb megismerésén túl a gyorsan változó fehérjék evolúciójának megértéséhez is hozzájárulhat. Egy 2009-ben megjelent tanulmány szerint a gének evolúciós sebessége és a gén kora egyértelmű összefüggést mutatnak; a fiatal gének gyorsan, míg az idősebb gének lassabban evolválódnak [Wolf et al. 2009]. Mivel ez az összefüggés egyetemesnek bizonyult, arra következtethetünk, hogy a mai konzervált gének a kialakulásukkor még gyors evolúcióval rendelkeztek. A mai gyors evolúciót mutató gének tehát e tekintetben hasonlíthatnak az élet hajnalán kialakultakhoz. A Ver fehérje így egy telomer szerepére nemrég evolválódott DNS kötő fehérje, melyben csak a térszerkezetet kialakító, illetve a DNS-kötésben részt vevő aminosavak konzerválódására van szükség, hogy a DNS-kötő funkcióját ellássa. Mivel a többi aminosavra lényegesen kisebb szelekciós nyomás nehezedik, a fehérje felszíne gyorsan változhat. A változó felszín pedig evolúciós lehetőséget hordoz magában, hogy új interakciós felszínné formálódjon. Amennyiben ez megtörténik és az újonnan kialakult interakció előnyösebb, akkor a felszín konzerválódhat. Ehhez első lépésben csak a megfelelő térszerkezetet kialakító, és az interakcióban részt vevő aminosavak konzervációja szükséges, majd az optimális szerkezet létrejöttével az evolúció üteme lassul. Ennek megfelelően a fiatal gének kevés funkcióval gyorsan evolválódnak, míg az idősebb génekről képződő fehérjék felszínei egyre konzerváltabbak, hogy megőrizzék a fontos kölcsönhatásokat és elkerüljék az előnyteleneket.

Beláttuk, hogy a terminin fehérjék evolúciós sebessége nagymértékben hasonlít más, a fajképzésben közremúködő fehérjékére, azonban nem találtunk egyértelmű bizonyítékot ennek alátámasztásához. A feltételezett fajképzésben játszott szerep más ezzel kapcsolatba hozott fehérjéknél is megkérdőjelezhető. Így például a $D$. melanogaster Hmr fehérjék hibrid letalitást okoznak, míg a $D$. simulans Hmr fehérjék nem [Barbash et al. 2004]. Eredményeink alapján ugyanez a terminin komplex fehérjéi esetében is feltételezhető. Nem zárható ki, hogy más fajok és más terminin fehérjék bevonásával talán megtalálnánk a hipotézisünket támogató fehérjekombinációt, azonban ehhez új metodikát kell kidolgozni, mivel az általam alkalmazott alacsony áteresztő képességű módszer nem 
lenne célszerű ilyen jellegű vizsgálatokhoz. Megfelelő metodika lenne például az élesztő két-hibrid rendszer alkalmazása, mert nem igényli a fehérjék tisztítását a kölcsönhatás kimutatásához, vagy in vitro transzlációval eloállított fehérjék vizsgálata, mely szintén jelentősen gyorsítaná az interakciók vizsgálatát. A keresést megkönnyítené továbbá a fehérjék térszerkezetének ismerete, ahogyan a Ver térszerkezeti modellje is segítséget adott a dolgozatomban bemutatott eredmények értékelésében.

A kutatásunk során számos kérdésünkre választ kaptunk. Megállapítottuk, hogy a terminin fehérjék interakciós doménjei magas mutációs rátával fejlődnek. Sikerült kimutatni, hogy a terminin holokomplex két alkomplexből szerveződik. Vizsgáltuk a Ver-DTL alegység DNS kötő képességét és megállapítottuk, hogy az egyes-szálú DNS-hez mutat nagyobb affinitást. Sikeresen létrehoztunk egy múködőképes hibrid Ver-DTL dimert, és Ver fehérje térszerkezeti modelljét, melyek alapján azt feltételezzük, hogy a Ver-DTL interakció konzervált felszíneken valósul meg. A válaszok sok esetben újabb kérdésekhez és hipotézisek megfogalmazásához vezettek. Ilyen hipotézis például az DTL-Ver komplex szerepéről alkotott hipotézisünk az ATR útvonal gátlásában, vagy egyéb elképzeléseink az evolúciósan fiatal fehérjék alacsony konzerváltságának magyarázatára. A terminin fehérjék esetleges szerepe a fajképzésben eredményeim ellenére továbbra sem kizárható, de annak igazolása további kísérleteket igényel. 


\section{Köszönetnyilvánítás}

Szeretnék köszönetet mondani témavezetőimnek, Boros Imrének és Blastyák Andrásnak, munkájukért, segítségükért, útmutatásaikért és szemléletformáló tanácsaikért.

Köszönöm Ősz-Pápai Juditnak és Laczka Csillának a baculovírus rendszer felállításához nyújtott segítségüket.

Köszönettel tartozom Hunyadi-Gulyás Évának és Darula Zsuzsannának a tömegspektrometriás mérések elvégzéséért.

Köszönöm Sonja Lukicnak a bioréteg interferencia kísérletek elvégzését.

Szeretném megköszönni Ökrösné Katalinnak, hogy rendelkezésemre bocsátotta a $D$. yakuba Ver szekvenciáját tartalmazó plazmidjait.

Hálás vagyok Csebella-Bakota Adriennek és Pataki Edinának, akiknek segítsége lehetővé tette a kutatások gördülékeny menetét.

Köszönet illeti továbbá Laurinyecz Barbarát és Vedelek Viktort dolgozatom megírásához nyújtott tanácsaikért.

Köszönöm a szüleimnek és családomnak szeretetüket, sok éves támogatásukat, hogy lehetővé tették tanulmányaim zavartalan végzését.

OTKA K 100969 - Telomer fehérjék múködése, evolúciója és lehetséges szerepe fajok képződésében

GINOP-2.3.2-15-2016-00032 - A sejtek fehérjeháztartását szabályozó folyamatok vizsgálata újszerű genetikai és proteomikai módszerekkel 


\section{Irodalomjegyzék}

(Abad et al. 2004) Abad JP, De Pablos B, Osoegawa K, De Jong PJ, Martín-Gallardo A, Villasante A. (2004) TAHRE, a novel telomeric retrotransposon from Drosophila melanogaster, reveals the origin of Drosophilatelomeres. Mol Biol Evol. 2004 Sep;21(9):1620-4. Epub 2004 Jun 2.

(Ayala és Coluzzi 2005) Ayala FJ, Coluzzi M. (2005) Chromosome speciation: humans, Drosophila, and mosquitoes. Proc Natl Acad Sci U S A. 2005 May 3;102 Suppl 1:6535-42. Epub 2005 Apr 25.

(Azzalin et al. 2007) Azzalin CM, Reichenback P, Khoriauli L, Giulotto E, Lingner J. (2007) Telomeric Repeat Containing RNA and RNA Surveillance Factors at Mammalian Chromosome Ends. Science 2007;318:798-801. [PubMed: 17916692]

(Barbash et al. 2004) Barbash DA, Awadalla P, Tarone AM. (2004) Functional divergence caused by ancient positive selection of a Drosophila hybridincompatibility locus. PLoS Biol. 2004 Jun;2(6):e142. Epub 2004 Jun 15.

(Baumann és Cech 2001) Baumann P, Cech TR. (2001) Pot1, the putative telomere end-binding protein in fission yeast and humans. Science. 2001 May 11;292(5519):1171-5.

(Bi et al. 2005) Bi X, Srikanta D, Fanti L, Pimpinelli S, Badugu R, Kellum R, Rong YS. (2005) Drosophila ATM and ATR checkpoint kinases control partially redundant pathways for telomere maintenance. Proc Natl Acad Sci U S A. 2005 Oct 18;102(42):15167-72. Epub 2005 Oct 3.

(Bianchi et al. 1997) Bianchi A, Smith S, Chong L, Elias P, de Lange T. (1997) TRF1 is a dimer and bends telomeric DNA. EMBO J. 1997 Apr 1;16(7):1785-94.

(Bidzinska et al. 2013) Bidzinska J, Cimino-Reale G, Zaffaroni N, Folini M. (2013) G-quadruplex structures in the human genome as novel therapeutic targets. Molecules. 2013 Oct 8;18(10):12368-95. doi: 10.3390/molecules181012368.

(Biessmann et al. 1992) Biessmann H, Champion LE, O'Hair M, Ikenaga K, Kasravi B, Mason JM (1992) Frequent transpositions of Drosophila melanogaster HeT-A transposable elements to receding chromosome ends. EMBO J. 1992 Dec; 11(12):4459-69.

(Bilaud et al. 1997) Bilaud T, Brun C, Ancelin K, Koering CE, Laroche T, Gilson E. (1997) Telomeric localization of TRF2, a novel human telobox protein. Nat Genet. 1997 Oct;17(2):236-9.

(Boughman 2002) Boughman, J. W. (2002). How sensory drive can promote speciation. Trends in Ecology and Evolution 17(12):571-577.

(Brideau et al. 2006) Brideau NJ, Flores HA, Wang J, Maheshwari S, Wang X, Barbash DA. (2006) Two Dobzhansky-Muller genes interact to cause hybrid lethality in Drosophila. Science. 2006 Nov 24;314(5803):1292-5.

(Brideau et al. 2011) Brideau NJ, Barbash DA. (2011) Functional conservation of the Drosophila hybrid incompatibility gene Lhr. BMC Evol Biol. 2011 Mar 2;11:57. doi: 10.1186/1471-2148-11-57. 
(Capkova Frydrychova et al. 2008) Capkova Frydrychova R, Biessmann H, Mason JM. (2008) Regulation of telomere length in Drosophila. Cytogenet Genome Res. 2008;122(3-4):356-64. doi: 10.1159/000167823. Epub 2009 Jan 30.

(Carpenter 1905) Carpenter FW (1905) The reactions of the pomace fly (Drosophila ampelophila Loew) to light, gravity, and mechanical stimulation. American Naturalist 39: 157-171.

(Cenci 2009) G. Cenci (2009) Drosophila cell cycle under arrest Cell Cycle 8:7, 990-995; 1 April 2009]; (C2009 Landes Bioscience

(Cenci et al. 1997 ) Cenci G, Rawson RB, Belloni G, Castrillon DH, Tudor M, Petrucci R, Goldberg ML, Wasserman SA, Gatti M. (1997) UbcD1, a Drosophila ubiquitin-conjugating enzyme required for proper telomere behavior. Genes Dev. 1997 Apr 1;11(7):863-75.

(Cenci et al. 2003) Cenci G, Siriaco G, Raffa GD, Kellum R, Gatti M. (2003) The Drosophila HOAP protein is required for telomere capping. Nat Cell Biol. 2003 Jan;5(1):82-4.

(Cenci et al. 2003) Cenci G, Siriaco G, Gatti M. (2003) The role of HeT-A and TART retrotransposons in Drosophila telomere capping. Genetica. 2003 Mar;117(2-3):311-8.

(Cenci et al. 2005) Cenci G, Ciapponi L, Gatti M. (2005) The mechanism of telomere protection: a comparison between Drosophila and humans. Chromosoma. 2005 Aug;114(3):135-45. Epub 2005 Jul 13.

(Cenci et al. 2015) Cenci G, Ciapponi L, Marzullo M, Raffa GD, Morciano P, Raimondo D, Burla R, Saggio I, Gatti M. (2015) The Analysis of Pendolino (peo) Mutants Reveals Differences in the Fusigenic Potential among DrosophilaTelomeres. PLoS Genet. 2015 Jun 25;11(6):e1005260. doi: 10.1371/journal.pgen.1005260. eCollection 2015.

(Ciapponi et al. 2004) Ciapponi L, Cenci G, Ducau J, Flores C, Johnson-Schlitz D, Gorski MM, Engels WR, Gatti M. (2004) The Drosophila Mre11/Rad50 complex is required to prevent both telomeric fusion and chromosome breakage. Curr Biol. 2004 Aug 10;14(15):1360-6.

(Ciapponi et al. 2006) Laura Ciapponi, Giovanni Cenci, Maurizio Gatti (2006) The Drosophila Nbs Protein Functions in Multiple Pathways for the Maintenance of Genome Stability Genetics Society of America DOI: 10.1534/genetics.106.058081

(Clark és Elgin 1992) R F Clark and S C Elgin (1992) Heterochromatin protein 1, a known suppressor of positioneffect variegation, is highly conserved in Drosophila. Nucleic Acids Res. Nov 25, 1992; 20(22): 60676074.

(de Lange 2004) de Lange T.(2004) T-loops and the origin of telomeres. Nat Rev Mol Cell Biol. 2004 Apr;5(4):323-9.

(Deng et al. 2009) Deng Z, Norseen J, Wiedmer A, Riethman H, Lieberman PM. (2009) TERRA RNA binding to TRF2 facilitates heterochromatin formation and ORC recruitment at telomeres. Mol Cell. 2009 Aug 28;35(4):403-13. doi: 10.1016/j.molcel.2009.06.025.

(Diebold et al. 2011) Diebold ML, Fribourg S, Koch M, Metzger T, Romier C. (2011) Deciphering correct strategies for multiprotein complex assembly by co-expression: application to complexes as large as 
the histone octamer. J Struct Biol. 2011 Aug;175(2):178-88. doi: 10.1016/j.jsb.2011.02.001. Epub 2011 Feb 12.

(Diotti és Loayza 2011) Diotti R, Loayza D. (2011) Shelterin complex and associated factors at human telomeres. Nucleus. 2011 Mar-Apr;2(2):119-35. doi: 10.4161/nucl.2.2.15135.

(Dobie et al. 1999) Dobie KW, Hari KL, Maggert KA, Karpen GH. (1999) Centromere proteins and chromosome inheritance: a complex affair. Curr Opin Genet Dev. 1999 Apr;9(2):206-17.

(Dubruille et al. 2012) Rapha“elle Dubruille, Gabriel A. B.Marais, and Benjamin Loppin (2012) Repeated Evolution of Testis-Specific New Genes: The Case of Telomere-Capping Genes in Drosophila Hindawi Publishing Corporation International Journal of Evolutionary Biology Volume 2012, Article ID 708980, 11 pages doi:10.1155/2012/708980

(Dyson és Wright 2005) Dyson HJ, Wright PE. 2005, Intrinsically unstructured proteins and their functions. Nat Rev Mol Cell Biol. 2005 Mar;6(3):197-208.

(Eissenberg et al 1990) Eissenberg JC, James TC, Foster-Hartnett DM, Hartnett T, Ngan V, Elgin SC (1990) Mutation in a heterochromatin-specific chromosomal protein is associated with suppression of position-effect variegation in Drosophila melanogaster. Proc Natl Acad Sci U S A. 1990 Dec; 87(24):9923-7.

(Fanning et al. 2006) Fanning E, Klimovich V, Nager AR. (2006) A dynamic model for replication protein A (RPA) function in DNA processing pathways. Nucleic Acids Res. 2006;34(15):4126-37. Epub 2006 Aug 25.

(Fanti et al. 1998) Fanti L, Giovinazzo G, Berloco M, Pimpinelli S. (1998) The heterochromatin protein 1 prevents telomere fusions in Drosophila. Mol Cell. 1998 Nov;2(5):527-38.

(Flynn wt al. 2011) Flynn RL, Centore RC, O'Sullivan RJ, Rai R, Tse A, Songyang Z, Chang S, Karlseder J, Zou L. (2011) TERRA and hnRNPA1 orchestrate an RPA-to-POT1 switch on telomeric single-stranded DNA. Nature. 2011 Mar 24;471(7339):532-6. doi: 10.1038/nature09772. Epub 2011 Mar 13.

(Fukagawa 2013) Fukagawa T (2013) Speciation mediated by centromeres. Dev Cell. 2013 Nov 25;27(4):367-8. doi: 10.1016/j.devcel.2013.11.005.

(Fulcher 2014) Fulcher N, Derboven E, Valuchova S, Riha K. (2014) If the cap fits, wear it: an overview of telomeric structures over evolution Cell Mol Life Sci. 2014 Mar;71(5):847-65. doi: 10.1007/s00018013-1469-z. Epub 2013 Sep 17.

(Gao et al. 2010) Gao G, Walser JC, Beaucher ML, Morciano P, Wesolowska N, Chen J, Rong YS. (2010) HipHop interacts with HOAP and HP1 to protect Drosophila telomeres in a sequence-independent manner. EMBO J. 2010 Feb 17;29(4):819-29. doi: 10.1038/emboj.2009.394. Epub 2010 Jan 7.

(Gao et al. 2011) Gao G, Cheng Y, Wesolowska N, Rong YS. (2011) Paternal imprint essential for the inheritance of telomere identity in Drosophila. Proc Natl Acad Sci U S A. 2011 Mar 22;108(12):4932-7. doi: 10.1073/pnas.1016792108. Epub 2011 Mar 7.

(Gavrilets 2003) Gavrilets S. (2003) Perspective: models of speciation: what have we learned in 40 years? Evolution. 2003 Oct;57(10):2197-215. 
(Gomes et al. 2000) Gomes XV, Gary SL, Burgers PM. (2000) Overproduction in Escherichia coli and characterization of yeast replication factor C lacking the ligase homology domain. J Biol Chem. 2000 May 12;275(19):14541-9.

(Gomez et al. 2004) Gomez D, Paterski R, Lemarteleur T, Shin-Ya K, Mergny JL, Riou JF. (2004) Interaction of telomestatin with the telomeric single-strand overhang. J Biol Chem. 2004 Oct 1;279(40):41487-94. Epub 2004 Jul 23.

(Greider és Blackburn 1985) Greider CW, Blackburn EH. (1985) Identification of a specific telomere terminal transferase activity in Tetrahymena extracts. Cell. 1985 Dec;43(2 Pt 1):405-13.

(Griffith et al. 1999) , Griffith J. D. Comeau L, Rosenfield S, Stansel RM, Bianchi A, Moss H, de Lange T (1999) Mammalian telomeres end in a large duplex loop. Cell 97, 503-514 (1999).

(Griffith et al. 1999) Griffith JD, Comeau L, Rosenfield S, Stansel RM, Bianchi A, Moss H, de Lange T. (1999) Mammalian telomeres end in a large duplex loop. Cell. 1999 May 14;97(4):503-14

(Guardino et al. 2009) Guardino KM, Sheftic SR, Slattery RE, Alexandrescu AT (2009) Relative stabilities of conserved and non-conserved structures in the OB-fold superfamily. Int J Mol Sci. 2009 May 22;10(5):2412-30. doi: 10.3390/ijms10052412.

(Henricksen et al. 1994) Henricksen LA, Umbricht CB, Wold MS. (1994) Recombinant replication protein A: expression, complex formation, and functional characterization. J Biol Chem. 1994 Apr 15;269(15):11121-32.

(Hoskin et al. 2005) Hoskin CJ, Higgie M, McDonald KR, Moritz C. (2005) Reinforcement drives rapid allopatric speciation. Nature. 2005 Oct 27;437(7063):1353-6.

(Hurley et al. 2000) Hurley LH, Wheelhouse RT, Sun D, Kerwin SM, Salazar M, Fedoroff OY, Han FX, Han H, Izbicka E, Von Hoff DD. (2000) G-quadruplexes as targets for drug design. Pharmacol Ther. 2000 Mar;85(3):141-58.

(Hurst 2002) Hurst LD. (2002) The Ka/Ks ratio: diagnosing the form of sequence evolution.Trends Genet. 2002 Sep;18(9):486.

(Inoue et al. 1990) Inoue H, Nojima H, Okayama H. (1990) High efficiency transformation of Escherichia coli with plasmids. Gene. 1990 Nov 30;96(1):23-8.

(Inoue et al. 1990) Inoue H, Nojima H, Okayama H. (1990) High efficiency transformation of Escherichia coli with plasmids. Gene. 1990 Nov 30;96(1):23-8.

(James és Elgin 1986) James TC, Elgin SC. (1986) Identification of a nonhistone chromosomal protein associated with heterochromatin in Drosophila melanogaster and its gene. Mol Cell Biol. 1986;6:3862-3872.

(James és Gaunt 1991) James, T. C. and Gaunt, S. J. (1991). A sequence motif found in a Drosophila heterochromatin protein is conserved in animals and plants. Nucl. Acids Res. 19, 789-794.

(Janin és Sternberg 2013) Janin J, Sternberg MJ. 2013, Protein flexibility, not disorder, is intrinsic to molecular recognition. F1000 Biol Rep. 2013;5:2. doi: 10.3410/B5-2. Epub 2013 Jan 11. 
(Joppich et al. 2009) Christian Joppich \& Sabrina Scholz \& Günter Korge \& Alexander Schwendemann (2009) Umbrea, a chromo shadow domain protein in Drosophila melanogaster heterochromatin, interacts with Hip, HP1 and HOAP Chromosome Research (2009) 17:19-36 DOI 10.1007/s10577-008-9002-1

(Kaltenegger és Ober 2015) Kaltenegger E, Ober D (2015) Paralogue Interference Affects the Dynamics after Gene Duplication. Trends Plant Sci. 2015 Dec;20(12):814-21. doi: 10.1016/j.tplants.2015.10.003. Epub 2015 Nov 27.

(Kelley et al. 2015) Kelley LA, Mezulis S, Yates CM, Wass MN, Sternberg MJ. (2015) The Phyre2 web portal for protein modeling, prediction and analysis. Nat Protoc. 2015 Jun;10(6):845-58. doi: 10.1038/nprot.2015.053. Epub 2015 May 7.

(Khurana et al 2010) Khurana JS, Xu J, Weng Z, Theurkauf WE. (2010) Distinct functions for the Drosophila piRNA pathway in genome maintenance and telomere protection. PLoS Genet. 2010 Dec 16;6(12):e1001246. doi: 10.1371/journal.pgen.1001246.

(Kim et al. 1999) Kim SH, Kaminker P, Campisi J. (1999) TIN2, a new regulator of telomere length in human cells. Nat Genet. 1999 Dec;23(4):405-12.

(Komonyi et al 2009) Komonyi O, Schauer T, Papai G, Deak P, Boros IM. (2009) A product of the bicistronic Drosophila melanogaster gene CG31241, which also encodes a trimethylguanosine synthase, plays a role in telomere protection. J Cell Sci. 2009 Mar 15;122(Pt 6):769-74. doi: 10.1242/jcs.035097. Epub 2009 Feb 24.

(Komonyi et al. 2005) Komonyi O, Pápai G, Enunlu I, Muratoglu S, Pankotai T, Kopitova D, Maróy P, Udvardy A, Boros I. (2005) DTL, the Drosophila homolog of PIMT/Tgs1 nuclear receptor coactivator-interacting protein/RNA methyltransferase, has an essential role in development. J Biol Chem. 2005 Apr 1;280(13):12397-404. Epub 2005 Jan 31.

(Koonin et al 1995) Koonin EV, Zhou S, Lucchesi JC (1995) The chromo superfamily: new members, duplication of the chromo domain and possible role in delivering transcription regulators to chromatin. Nucleic Acids Res. 1995 Nov 11; 23(21):4229-33.

(Kosugi et al. 2009) Kosugi S., Hasebe M., Tomita M., and Yanagawa H. (2009) Systematic identification of yeast cell cycle-dependent nucleocytoplasmic shuttling proteins by prediction of composite motifs. Proc. Natl. Acad. Sci. USA 106, 10171-10176.

(Könyv: Korber 2000) Korber B. (2000). HIV Signature and Sequence Variation Analysis. Computational Analysis of HIV Molecular Sequences, Chapter 4, pages 55-72. Allen G. Rodrigo and Gerald H. Learn, eds. Dordrecht, Netherlands: Kluwer Academic Publishers.

(Krempels 2006) Dana Krempels Spring 2006, Lecture Notes for EVOLUTION AND BIODIVERSITY class (BIL 160 Section HJ) Univ. Of Miami - https://en.wikipedia.org/wiki/File:Speciation_modes.png

(Kulathinal és Singh 2008) Kulathinal RJ, Singh RS. (2008) The molecular basis of speciation: from patterns to processes, rules to mechanisms. J Genet. 2008 Dec;87(4):327-38.

(Lachner et al 2001) Lachner M, O'Carroll D, Rea S, Mechtler K, Jenuwein T. (2001) Methylation of histone H3 lysine 9 creates a binding site for HP1 proteins. Nature. 2001 Mar 1;410(6824):116-20.

79. 
(Levine et al 2012) Levine MT, McCoy C, Vermaak D, Lee YC, Hiatt MA, Matsen FA, Malik HS. (2012) Phylogenomic analysis reveals dynamic evolutionary history of the Drosophila heterochromatin protein 1 (HP1) gene family. PLoS Genet. 2012;8(6):e1002729. doi: 10.1371/journal.pgen.1002729. Epub 2012 Jun 21

(Levis et al. 1993) Levis RW, Ganesan R, Houtchens K, Tolar LA, Sheen FM. (1993) Transposons in place of telomeric repeats at a Drosophila telomere. Cell. 1993 Dec 17;75(6):1083-93.

(Li et al. 2000) Li B, Oestreich S, de Lange T. (2000) Identification of human Rap1: implications for telomere evolution. Cell. 2000 May 26;101(5):471-83.

(Linding et al. 2003) Linding R, Russell RB, Neduva V, Gibson TJ. (2003) GlobPlot: Exploring protein sequences for globularity and disorder. Nucleic Acids Res. 2003 Jul 1;31(13):3701-8.

(Liu et al. 2004) Liu D, O'Connor MS, Qin J, Songyang Z. (2004) Telosome, a mammalian telomere-associated complex formed by multiple telomeric proteins. J Biol Chem. 2004 Dec 3;279(49):51338-42. Epub 2004 Sep 20.

(Louis 2002) Louis EJ. (2002) Are Drosophila telomeres an exception or the rule? Genome Biol. 2002 Sep 27;3(10):REVIEWS0007. Epub 2002 Sep 27.

(Lu et. al 2013) Lu X, Wontakal SN, Kavi H, Kim BJ, Guzzardo PM, Emelyanov AV, Xu N, Hannon GJ, Zavadil J, Fyodorov DV, Skoultchi (2013) Drosophila H1 regulates the genetic activity of heterochromatin by recruitment of Su(var)3-9 Science: Al.Apr 5;340(6128):78-81. doi: 10.1126/science.1234654.

(Lydall 2009) Lydall D. (2009) Taming the tiger by the tail: modulation of DNA damage responses by telomeres. EMBO J. 2009 Aug 5;28(15):2174-87. doi: 10.1038/emboj.2009.176. Epub 2009 Jul 23.

(Mallet 2006) Mallet J. (2006) What does Drosophila genetics tell us about speciation? Trends Ecol Evol. 2006 Jul;21(7):386-93. Epub 2006 Jun 9.

(Masly 2012) Masly JP. (2012) 170 Years of "Lock-and-Key": Genital Morphology and Reproductive Isolation. Int J Evol Biol. 2012;2012:247352. doi: 10.1155/2012/247352. Epub 2011 Dec

(Mason és Biessmann 1995) Mason JM, Biessmann H (1995) The unusual telomeres of Drosophila. Trends Genet. 1995 Feb; 11(2):58-62.

(Mason és Biessmann 1995) Mason JM, Biessmann H.(1995) The unusual telomeres of Drosophila Trends Genet. 1995 Feb;11(2):58-62.

(Mason et al. 2004) Mason JM, Ransom J, Konev AZ (2004) A deficiency screen for dominant suppressors of telomeric silencing in Drosophila. Genetics. 2004 Nov; 168(3):1353-70.

(Mason et al. 2008) Mason JM, Frydrychova RC, Biessmann H. (2008) Drosophila telomeres: an exception providing new insights. Bioessays. 2008 Jan;30(1):25-37.

(Mayr 1942) Mayr, E. (1942) Systematics and the Origin of Species (Columbia Univ. Press, New York).

(McClintock 1941) McClintock, B. (1941) The stability of broken ends of chromosomes in Zea mays. Genetics 26 : 234-282.

(McClintock 1942) McClintock, B. (1942) The fusion of broken ends of chromosomes following nuclear fusion. Proc. Natl. Acad. Sci. 28: 458-463. 
(Mechler et al. 1985) Mechler BM, McGinnis W, Gehring WJ (1985) Molecular cloning of lethal(2)giant larvae, a recessive oncogene of Drosophila melanogaster. EMBO J. 1985 Jun; 4(6):1551-7.

(Mihola 2009) Mihola O, Trachtulec Z, Vlcek C, Schimenti JC, Forejt J. (2009) A mouse speciation gene encodes a meiotic histone H3 methyltransferase. Science. 2009 Jan 16;323(5912):373-5. doi: 10.1126/science.1163601. Epub 2008 Dec 11.

(Mishima et al 2012) Mishima Y, Watanabe M, Kawakami T, Jayasinghe CD, Otani J, Kikugawa Y, Shirakawa M, Kimura H, Nishimura O, Aimoto S, Tajima S, Suetake I. (2012) Hinge and chromoshadow of HP1 $\alpha$ participate in recognition of $\mathrm{K} 9$ methylated histone H3 in nucleosomes. J Mol Biol. 2013 Jan 9;425(1):54-70. doi: 10.1016/j.jmb.2012.10.018. Epub 2012 Nov 6.

(Morgan 1903) Morgan TH (1903) Evolution and Adaptation. Macmillan \& Co., New York, NY, USA and London, UK.

(Muller 1938) Muller HJ. 1938. The remaking of chromosomes. Collecting Net 8:181-195.

(Mullins et al. 2016) Mullins MR, Rajavel M1, Hernandez-Sanchez W, de la Fuente M, Biendarra SM, Harris ME, Taylor DJ. (2016) POT1-TPP1 Binding and Unfolding of Telomere DNA Discriminates against Structural Polymorphism. J Mol Biol. 2016 Jul 3;428(13):2695-708. doi: 10.1016/j.jmb.2016.04.031. Epub 2016 May 10.

(Musarò et al. 2008) Musarò M, Ciapponi L, Fasulo B, Gatti M, Cenci G. (2008) Unprotected Drosophila melanogaster telomeres activate the spindle assembly checkpoint. Nat Genet. 2008 Mar;40(3):362-6. doi: 10.1038/ng.2007.64. Epub 2008 Feb 3.

(Nandakumar et al 2012) Nandakumar J, Bell CF, Weidenfeld I, Zaug AJ, Leinwand LA, Cech TR. (2012) The TEL patch of telomere protein TPP1 mediates telomerase recruitment and processivity. Nature. 2012 Dec 13;492(7428):285-9. doi: 10.1038/nature11648. Epub 2012 Oct 24.

(Nei és Nozawa 2011) Nei M, Nozawa M. (2011) Roles of mutation and selection in speciation: from Hugo de Vries to the modern genomic era. Genome Biol Evol. 2011;3:812-29. doi: 10.1093/gbe/evr028.

(Notredame et al. 2000) Notredame C , Higgins DG , Heringa J (2000) T-Coffee: A novel method for fast and accurate multiple sequence alignment. Journal of molecular biology 302 (1) :205-17

(Nugent és Lundblad 1998) Nugent Cl, Lundblad V. (1998) The telomerase reverse transcriptase: components and regulation. Genes Dev. 1998 Apr 15;12(8):1073-85.

(Nugent és Lundblad 1998) Nugent, C. I. \& Lundblad, V. (1998) The telomerase reverse transcriptase: components and regulation. Genes Dev. 12, 1073-1085 (1998).

(Oganesian és Karlseder 2009) Oganesian L, Karlseder J. (2009) Telomeric armor: the layers of end protection. J Cell Sci. 2009 Nov 15;122(Pt 22):4013-25. doi: 10.1242/jcs.050567.

(Oikemus et al. 2006) Oikemus SR, Queiroz-Machado J, Lai K, McGinnis N, Sunkel C, Brodsky MH. (2006) Epigenetic telomere protection by Drosophila DNA damage response pathways. PLoS Genet. 2006 May;2(5):e71. Epub 2006 May 19. 
(Okonechnikov 2012) Okonechnikov K, Golosova O, Fursov M; UGENE team. (2012) Unipro UGENE: a unified bioinformatics toolkit. Bioinformatics. 2012 Apr 15;28(8):1166-7. doi: 10.1093/bioinformatics/bts091. Epub 2012 Feb 24

(Oliver et al. 2009) Oliver PL, Goodstadt L, Bayes JJ, Birtle Z, Roach KC, Phadnis N, Beatson SA, Lunter G, Malik HS, Ponting CP. (2009) Accelerated evolution of the Prdm9 speciation gene across diverse metazoan taxa. PLoS Genet. 2009 Dec;5(12):e1000753. doi: 10.1371/journal.pgen.1000753. Epub 2009 Dec 4.

(Olovnikov 1971) Olovnikov AM.(1971) [Principle of marginotomy in template synthesis of polynucleotides]. Dokl Akad Nauk SSSR. 1971;201(6):1496-9.

(Palm és Lange 2008) Palm W, de Lange T. (2008) How shelterin protects mammalian telomeres. Annu Rev Genet. 2008;42:301-34. doi: 10.1146/annurev.genet.41.110306.130350.

(Pardue és DeBaryshe 2003) Pardue ML, DeBaryshe PG. (2003) Retrotransposons provide an evolutionarily robust non-telomerase mechanism to maintain telomeres. Annu Rev Genet. 2003;37:485-511.

(Pardue és ML, DeBaryshe 2003) Pardue ML, DeBaryshe PG. (2003) Retrotransposons provide an evolutionarily robust non-telomerase mechanism to maintain telomeres. Annu Rev Genet. 2003;37:485-511.

(Pegi et al. 2008) Jimin Pei, Bong-Hyun Kim and Nick V. Grishin. (2008) PROMALS3D: a tool for multiple sequence and structure alignment. Nucleic Acids Res. 2008 36(7):2295-2300.

(Perrini et al 2004) Perrini B, Piacentini L, Fanti L, Altieri F, Chichiarelli S, Berloco M, Turano C, Ferraro A, Pimpinelli S. (2004) HP1 controls telomere capping, telomere elongation, and telomere silencing by two different mechanisms in Drosophila. Mol Cell. 2004 Aug 13;15(3):467-76.

(Pettersen et al. 2004) Pettersen EF, Goddard TD, Huang CC, Couch GS, Greenblatt DM, Meng EC, Ferrin TE. (2004) UCSF Chimera--a visualization system for exploratory research and analysis. J Comput Chem. 2004 Oct;25(13):1605-12.

(Raffa et al 2013) Raffa GD, Cenci G, Ciapponi L, Gatti M. (2013) Organization and Evolution of Drosophila Terminin: Similarities and Differences between Drosophila and Human Telomeres. Front Oncol. 2013 May 10;3:112. doi: 10.3389/fonc.2013.00112

(Raffa et al. 2005) Raffa GD, Cenci G, Siriaco G, Goldberg ML, Gatti M. (2005) The putative Drosophila transcription factor woc is required to prevent telomeric fusions. Mol Cell. 2005 Dec 22;20(6):821-31.

(Raffa et al. 2009) Grazia D. Raffaa, Giorgia Siriacoa, Simona Cugusia, Laura Ciapponia, Giovanni Cencib, Edward Wojcikc, and Maurizio Gattia (2009) The Drosophila modigliani (moi) gene encodes a HOAP-interacting protein required for telomere protection PNAS February 17, 2009 vol. 106 no. 7 2271-2276

(Raffa et al. 2010) Raffa GD, Raimondo D, Sorino C, Cugusi S, Cenci G, Cacchione S, et al. (2010) Verrocchio, a Drosophila $\mathrm{OB}$ foldcontaining protein, is a component of the terminin telomere-capping complex Genes Dev 2010; 24:1596-601; PMID:20679394; DOI:10.1101/gad.574810.

(Raffa et al. 2011) Grazia D. Raffa, Laura Ciapponi, Giovanni Cenci and Maurizio Gatti (2011) Terminin A protein complex that mediates epigenetic maintenance of Drosophila telomeres Nucleus 2:5, 383-391; September/October 2011; (C) 2011 Landes Bioscience 
(Reinhardt és Jones 2013) Josephine A. Reinhardt Corbin D. Jones (2013) Two Rapidly Evolving Genes Contribute to Male Fitness in Drosophila J Mol Evol (2013) 77:246-259 DOI 10.1007/s00239-013-95948

(Reis et al. 2011) Reis M, Sousa-Guimarães S, Vieira CP, Sunkel CE, Vieira J. (2011) Drosophila genes that affect meiosis duration are among the meiosis related genes that are more often found duplicated. PLoS One. 2011 Mar 10;6(3):e17512. doi: 10.1371/journal.pone.0017512.

(Rendel 2003) Reddel RR (2003) Alternative lengthening of telomeres, telomerase, and cancer. Cancer Lett. 2003 May 15;194(2):155-62.

(Rendel et al. 1997) Reddel RR, Bryan TM, Murnane JP. (1997) Immortalized cells with no detectable telomerase activity. A review. Biochemistry (Mosc). 1997 Nov;62(11):1254-62.

(Reuter JS és Mathews DH. 2010) Reuter JS, Mathews DH. (2010) RNAstructure: software for RNA secondary structure prediction and analysis. BMC Bioinformatics. 2010 Mar 15;11:129. doi: 10.1186/1471-210511-129.

(Rieseberg 2001) Rieseberg LH. (2001) Chromosomal rearrangements and speciation. Trends Ecol Evol. 2001 Jul $1 ; 16(7): 351-358$

(Rosano és Ceccarelli 2014) Rosano GL, Ceccarelli EA (2014) Recombinant protein expression in Escherichia coli: advances and challenges. Front Microbiol. 2014 Apr 17;5:172. doi: 10.3389/fmicb.2014.00172. eCollection 2014.

(Sandell és Zakian 1993) Sandell LL, Zakian VA. (1993) Loss of a yeast telomere: arrest, recovery, and chromosome loss. Cell. 1993 Nov 19;75(4):729-39.

(Satyaki et al. 2014) Satyaki PR, Cuykendall TN, Wei KH, Brideau NJ, Kwak H, Aruna S, Ferree PM, Ji S, Barbash DA. (2014) The Hmr and Lhr hybrid incompatibility genes suppress a broad range of heterochromatic repeats. PLoS Genet. 2014 Mar 20;10(3):e1004240. doi: 10.1371/journal.pgen.1004240. eCollection 2014.

(Savitsky et al. 2002) Savitsky M, Kravchuk O, Melnikova L, Georgiev P. (2002) Heterochromatin protein 1 is involved in control of telomere elongation in Drosophila melanogaster. Mol Cell Biol. 2002 May;22(9):3204-18

(Savolainen et al. 2006) Savolainen V, Anstett MC, Lexer C, Hutton I, Clarkson JJ, Norup MV, Powell MP, Springate D, Salamin N, Baker WJ. (2006) Sympatric speciation in palms on an oceanic island. Nature. 2006 May 11;441(7090):210-3. Epub 2006 Feb 8.

(Schägger 1987) Schägger H, von Jagow G. (1987) Tricine-sodium dodecyl sulfate-polyacrylamide gel electrophoresis for the separation of proteins in the range from 1 to 100 kDa. Anal Biochem. $1987 \mathrm{Nov}$ 1;166(2):368-79.

(Schneider et al. 2012) Schneider CA, Rasband WS, Eliceiri KW. (2012) NIH Image to ImageJ: 25 years of image analysis. Nat Methods. 2012 Jul;9(7):671-5.

83. 
(Seetharam és Stuart 2013) Seetharam AS, Stuart GW. (2013) Whole genome phylogeny for 21 Drosophila species using predicted 2b-RAD fragments. PeerJ. 2013 Dec 23;1:e226. doi: 10.7717/peerj.226. eCollection 2013.

(Shareef et al. 2001) Shareef MM, King C, Damaj M, Badagu R, Huang DW, Kellum R. (2001) Drosophila heterochromatin protein 1 (HP1)/origin recognition complex (ORC) protein is associated with HP1 and ORC and functions in heterochromatin-induced silencing. Mol Biol Cell. 2001 Jun;12(6):1671-85.

(Siriaco et al. 2002) Siriaco GM, Cenci G, Haoudi A, Champion LE, Zhou C, Gatti M, Mason JM (2002) Telomere elongation (Tel), a new mutation in Drosophila melanogaster that produces long telomeres. Genetics. 2002 Jan; $160(1): 235-45$.

(Smothers és Henikoff 2000) Smothers JF, Henikoff S. (2000) The HP1 chromo shadow domain binds a consensus peptide pentamer. Curr Biol. 2000 Jan 13;10(1):27-30.

(Smothers és Henikoff 2001) Smothers JF, Henikoff S (2001) The hinge and chromo shadow domain impart distinct targeting of HP1-like proteins. Mol Cell Biol. 2001 Apr;21(7):2555-69.

(Stanke et al. 2004) Stanke M, Steinkamp R, Waack S, Morgenstern B. (2004) AUGUSTUS: a web server for gene finding in eukaryotes. Nucleic Acids Res. 2004 Jul 1;32(Web Server issue):W309-12.

(Sturtevant 1920) Sturtevant AH. (1920) Genetic Studies on DROSOPHILA SIMULANS. I. Introduction. Hybrids with DROSOPHILA MELANOGASTER. Genetics. 1920 Sep;5(5):488-500.

(Sun et al. 2006) Sun W, Gao S, Wang L, Chen Y, Wu S, Wang X, et al. (2006) Microwave-assisted protein preparation and enzymatic digestion in proteomics. Mol Cell Proteomics 2006;5:769-76

(Suyama et al 2006) Mikita Suyama, David Torrents, and Peer Bork (2006) PAL2NAL: robust conversion of protein sequence alignments into the corresponding codon alignments. Nucleic Acids Res. 34, W609W612.

(Templeton 1980) Templeton AR. (1980) The theory of speciation via the founder principle. Genetics. 1980 Apr;94(4):1011-38.

(Thomae et al. 2013) Thomae AW, Schade GO, Padeken J, Borath M, Vetter I, Kremmer E, Heun P, Imhof A. (2013) A pair of centromeric proteins mediates reproductive isolation in Drosophila species. Dev Cell. 2013 Nov 25;27(4):412-24. doi: 10.1016/j.devcel.2013.10.001. Epub 2013 Nov 14.

(Török et al. 2007)Török T, Benitez C, Takács S, Biessmann H. (2007) The protein encoded by the gene proliferation disrupter (prod) is associated with the telomeric retrotransposon array in Drosophila melanogaster. Chromosoma. 2007 Apr;116(2):185-95.

(Traverse és Pardue 1988) Traverse KL, Pardue ML. (1988) A spontaneously opened ring chromosome of Drosophila melanogaster has acquired He-T DNA sequences at both new telomeres. Proc Natl Acad Sci U S A. 1988 Nov;85(21):8116-20.

(van der Linde és Houle 2008) van der Linde, K. and Houle, D. (2008) A supertree analysis and literature review of the genus Drosophila and closely related genera (Diptera, Drosophilidae). Insect Syst. Evol. 39: 241267. Copenhagen, October 2008. ISSN1399-560X. 
(van Steensel és de Lange 1997) van Steensel, B. and T. de Lange. (1997) Control of telomere length by the human telomeric protein TRF1. Nature 385: 740-743.

(Vermaak és Malik 2009) Vermaak D, Malik HS. (2009) Multiple roles for heterochromatin protein 1 genes in Drosophila. Annu Rev Genet. 2009;43:467-92. doi: 10.1146/annurev-genet-102108-134802.

(Villasante et a. 2008) Villasante A, de Pablos B, Méndez-Lago M, Abad JP. (2008) Telomere maintenance in Drosophila: rapid transposon evolution at chromosome ends. Cell Cycle. 2008 Jul 15;7(14):2134-8. Epub 2008 May 12.

(Villasante et al. 2007) Alfredo Villasante, José P. Abad, Rosario Planelló, María Méndez-Lago, Susan E. Celniker, and Beatriz de Pablos (2007) Drosophila telomeric retrotransposons derived from an ancestral element that was recruited to replace telomerase Genome Res. 2007 Dec; 17(12): 1909-1918. doi: 10.1101/gr.6365107 PMCID: PMC2099598

(Walter et al. 2007) Walter MF, Biessmann MR, Benitez C, Török T, Mason JM, Biessmann H. (2007) Effects of telomere length in Drosophila melanogaster on life span, fecundity, and fertility. Chromosoma. 2007 Feb;116(1):41-51.

(Watson 1972) Watson JD. (1972) Origin of concatemeric T7 DNA Nat New Biol. 1972 Oct 18;239(94):197-201.

(Webb és Sali 2014) Benjamin Webb, Andrej Sali (2014) UNIT 5.6 Comparative Protein Structure Modeling Using MODELLER DOI: 10.1002/0471250953.bi0506s47 Published Online: 8 SEP 2014

(Williamson 1994) Williamson JR. (1994) G-quartet structures in telomeric DNA. Annu Rev Biophys Biomol Struct. 1994;23:703-30.

(Wolf et al. 2009) Wolf YI, Novichkov PS, Karev GP, Koonin EV, Lipman DJ. (2009) The universal distribution of evolutionary rates of genes and distinct characteristics of eukaryotic genes of different apparent ages. Proc Natl Acad Sci U S A. 2009 May 5;106(18):7273-80. doi: 10.1073/pnas.0901808106. Epub 2009 Apr 7.

(Xin et al. 2007) Xin H, Liu D, Wan M, Safari A, Kim H, Sun W, O'Connor MS, Songyang Z. (2007) TPP1 is a homologue of ciliate TEBP-beta and interacts with POT1 to recruit telomerase. Nature. 2007 Feb 1;445(7127):559-62. Epub 2007 Jan 21.

(Xu et al. 2007) Xu Y, Sato H, Shinohara K, Komiyama M, Sugiyama H. (2007) T-loop formation by human telomeric G-quadruplex. Nucleic Acids Symp Ser (Oxf). 2007;(51):243-4.

(Yang és Bielawski 2000) Yang Z, Bielawski JP. (2000) Statistical methods for detecting molecular adaptation. Trends Ecol Evol. 2000 Dec 1;15(12):496-503.

(Yao et al. 2003) Yao N, Coryell L, Zhang D, Georgescu RE, Finkelstein J, Coman MM, Hingorani MM, O'Donnell M. (2003) Replication factor C clamp loader subunit arrangement within the circular pentamer and its attachment points to proliferating cell nuclear antigen. J Biol Chem. 2003 Dec 12;278(50):50744-53. Epub 2003 Oct 6.

(Yasuda et al. 1995) Yasuda GK, Schubiger G, Wakimoto BT. (1995) Genetic characterization of ms (3) K81, a paternal effect gene of Drosophila melanogaster. Genetics. 1995 May;140(1):219-29. 
(Yurlova et al. 2009) Yurlova AA, Makunin IV, Kolesnikova TD, Posukh OV, Belyaeva ES, Zhimulev IF. (2009) Conservation of domain structure in a fast-evolving heterochromatic SUUR protein in drosophilids. Genetics. 2009 Sep;183(1):119-29. doi: 10.1534/genetics.109.104844. Epub 2009 Jul 13.

(Zou és Elledge 2003) Zou L, Elledge SJ. (2003) Sensing DNA damage through ATRIP recognition of RPA-ssDNA complexes. Science. 2003 Jun 6;300(5625):1542-8. 


\section{8. Összefoglaló}

Eukariótákban a lineáris kromoszómák végei egy speciális kromatin szerkezetbe szerveződnek, melyet telomernek nevezünk. A telomer meggátolja a különböző kromoszómák fúzióját és megakadályozza a kromoszóma végek degradációját, megőrizve a genom integritását. Ezekben a folyamatokban kulcsfontosságú szerepet játszik a telomer végét sapkaszerűen borító telomer capping komplex. Emlősökben shelterinnek nevezzük ezt a komplexet, melynek tagjai nagyfokú konzerváltságot mutatnak. A telomer biológiában érdekes kivételt képez a Drosophila nemzetség, mert ezekben a fajokban a telomer fenntartásának mechanizmusa és a capping komplex összetétele is jelentősen különbözik a kanonikustól. A Drosophila capping komplexet termininnek nevezzük. A terminin komplexet alkotó fehérjéknek nem ismertek homológjai a Drosophilák rokonsági körén kívül. Egyik legérdekesebb tulajdonságuk az, hogy gyors evolúciót mutatnak. A jelentős szekvencia különbségek ellenére ezek a fehérjék ugyanazt a funkciót látják el, és sok esetben ugyanazokkal a fehérjékkel hatnak kölcsön, mint más fajokban a kanonikus komplex tagjai.

A gyors evolúció és a létfontosságú funkció, melynek a Drosophila telomer capping komplexnek meg kell felelnie, ellentmondásosnak túnik. A sejtmúködés során a fontos funkciókhoz általában konzervált fehérjék látják el, mert a legtöbb változás a fehérje múködésképtelenné válását eredményezheti. Mégis előfordul, hogy egy-egy fontos funkciót gyorsan evolválódó protein lát el. Ilyen például egérben a PRDM9, mely a crossover kezdőpontok kijelölését végzi, vagy Drosophilában a Hmr és Lhr fehérjék, melyek a centromer kialakításában vesznek részt. Az evolúciós elmélet magyarázni képes, hogy egy élólény miért használhat mégis gyors evolúciójú fehérjét ilyen fontos molekuláris szerepek betöltésére. Úgy tartják, hogy a gyorsan változó, ugyanakkor esszenciális funkcióval rendelkező PRDM9 és a Hmr és Lhr fehérjéknek van egy fontos evolúciós szerepük, mégpedig az, hogy felgyorsítják a speciációs folyamatokat azáltal, hogy meggátolják a hibrid utódok létrejöttét.

Jelenleg nem bizonyított, hogy a Drosophila capping komplexnek van-e szerepe a hibrid sterilitásban, és ezzel a kromoszóma szintű reprodukciós izolációs mechanizmus része-e. Természetesen a gyors evolúció és konzervált funkció kettősségének feloldására más magyarázatokat is találhatunk, mint a fajképzésben betöltött szerep. Elképzelhető például, hogy a fehérjék múködéséhez és a térszerkezetük fenntartásához nem igénylik a teljes polipeptidlánc konzerválódását. Főként genetikai kísérletek alapján feltételezzük, hogy a Drosophila capping komplex öt fehérjéből áll, a Verrocchio, a DTL, a HOAP, a HipHop és a HP1 fehérjékből. A termininnek a HP1 az egyetlen konzervált tagja, 
melynek funkciója nem korlátozódik a telomerre, míg a többi fehérje gyors evolúciót mutat és csak a telomeren található meg.

Amennyiben két közel rokon fajból származó fehérje nem alkot komplexet, vagy a komplex funkciója sérül, akkor ezeknek a fehérjéknek szerepük lehet a fajképzésben. In vitro módszerekkel lehetőségünk van a fehérjék közti interakciónak és a DNS-kötésnek a vizsgálatára, azonban a terminin holokomplex összeállítására és vizsgálatára eddig még nem történtek ilyen jellegú kísérletek.

Munkám során az először bioinformatikai módszerekkel részletesen megvizsgáltam a Drosophila terminin fehérjék evolúciós sebességét. A számításokba 21 fajt bevonva megállapítottam, hogy a komplex tagjainak interakciós doménjei is felgyorsult evolúciót mutatnak. Ez azt jelenti, hogy a fehérjék közti interakciók nem konzervált doméneken keresztül valósulnak meg, mely alapján elképzelhető, hogy a közel rokon fajokból származó komplex tagok már nem képesek interakcióra. A fehérjék homológia alapú molekula modellezéssel is próbálkoztam, azonban csak a Ver esetében sikerült közel megbízható modellt előállítanom. Ezt követően a Ver térszerkezetet és az aminosav konzerváltsági értékeket együtt vizsgálva prediktáltam, a DNS-kötésben, a magi lokalizációban és a szerkezet kialakításában feltehetően fontos aminosavakat.

Immunprecipitációs adatok szerint, a Ver interakcióba lép a DTL-lel és a HOAP-pal, a DTL interakcióba lép a Ver, a HOAP és a HP1 proteinekkel, míg a HipHop kölcsön hat a HP1-gyel és a HOAP-pal, de nem lép kölcsönhatásba a Ver vagy a DTL fehérjékkel. A komplex további szerveződéséről, sztöchiometriájáról nincs információnk. Annak érdekében, hogy az öt fehérjéből álló komplexet izoláljuk, bakteriális rendszerben termeltettük a Drosophila melanogaster fehérjéket. Sikeresen előállítottam a HP1, a HOAP, a Ver és a DTL proteineket, a HipHop expressziós szintje azonban többféle expressziós plazmidot és indukciós körülményt kipróbálva is alacsony maradt. Mivel az interakciós adatok arra utalnak, hogy a HipHop nélkül is kialakulhat egy stabil komplex, a későbbiekben csak a sikerrel expresszált négy fehérjét vizsgáltuk.

A Ver és a DTL fehérjék magas expressziós szintet mutattak ugyan, azonban oldhatatlan formában, „inclusion body”-ban keletkeztek a baktériumban. A terminin fehérjék oldhatóságán sokat javított az együttes termelésük, ami lehetővé tette tisztításukat is. A négy fehérjét tartalmazó komplex tisztításának első lépéseként a fehérjéket a DNS-kötő fehérjék izolálására gyakran alkalmazott heparin-sepharose oszlopra kötöttem. Az oszlopról történő elúció során a terminin fehérjék több alkomplex formájában jelentek meg a frakciókban. A Ver és DTL fehérjék alacsony sókoncentráció mellett, míg a HOAP, a HP1 (és a HipHop) fehérjék magas sókoncentráció mellett távoztak az oszlopról. A négy fehérje közös elúcióját az elválasztás során alkalmazott sókoncentráció 
változtatásával sem lehetett elérni, helyette két alkomplexet azonosítottunk. A Ver és a DTL egyértelmúen egy stabil heterodimert alkotott, míg a HOAP és a HP1 egy nehezebben meghatározható sztöchiometriájú másik komplexbe szerveződött. Ez az elkülönülő két komplex összeegyeztethető az irodalomból ismert funkcionális elkülönüléssel, miszerint a Ver és a DTL az egyes-szálú DNS hibajavítási mechanizmusok gátlásában vesznek részt, míg a HOAP, a HP1 és a HipHop a kettős-szálú DNS hibajavítás gátlásában.

A további vizsgálatokhoz a Ver-DTL heterodimert választottuk és a két fehérje kifejeződését egyszerre biztosító plazmidot hoztunk létre. A fajképzésben betöltött szerep vizsgálatára készítettünk egy olyan plazmid konstrukciót is, amely egy közeli rokonból, a Drosophila yakuba fajból származó Ver ortológ és $D$. melanogaster DTL kódoló régióját tartalmazza. Az expressziót követően heparinsepharose oszlopon tisztítottuk mind a kétféle plazmidról expresszált fehérjéket. A számunkra érdekes proteineket tartalmazó frakciókat immunaffinitás kromatográfiával és méretkizárásos kromatográfiával is tovább vizsgáltuk. Eredményeink alapján a $D$. yakuba Ver és a $D$. melanogaster DTL fehérjék a köztük lévő szekvencia különbségek ellenére - a $D$. melanogaster Ver-DTL dimerhez hasonlóan - stabil komplexet alkotnak. A Ver-DTL dimerek DNS-kötő képességét is megvizsgáltuk. Ehhez mágneses gyöngyökre egyes-szálú, kettős-szálú és 3’ túlnyúló végú oligonukleotidokat kötöttünk és megállapítottuk, hogy a különböző DNS konformációk mennyi fehérje megkötésére alkalmasak. A kísérlet eredményei alapján mind a $D$. melanogaster, mind a hibrid heterodimer nagyobb affinitással kötötte az egyes-szálú DNS-t, mint a kettős-szálút. Ezt az eredményt bioréteg interferencia mérésekkel is megerősítettük.

A Ver térszerkezeti modellje alapján feltételezhetjük, hogy a Ver-DTL interakció a Ver részéről egy konzervált felszínen valósulhat meg, ami azt jelenti, hogy a gyors evolúció nem az interakciókban részt vevő aminosavakat érinti. Ezért a Ver és a DTL esetében valószínútlen, hogy a fehérjék gyors változása hozzájáruljon a fajképzéshez az alkomplex funkcióvesztése miatt. Más módon természetesen a fehérjék még működhetnek fajképzési korlátként, például hasonlóan a Hmr és Lhr proteinekhez, amik között létrejövő interakció ehhez a funkcióhoz elengedhetetlen.

Munkámmal hozzájárultam a Drosophila telomer capping komplex esszenciális funkciója és a gyors evolúciója között látszó ellentmondás feloldásához. Habár a terminin fehérjék fajképzésben betöltött szerepére nem találtam egyértelmú bizonyítékot, biokémiai megközelítéssel új adatokat nyertem a telomer capping komplexről. A Ver, illetve a Ver-DTL alkomplex vizsgálatával bemutattam, hogy hogyan lehetséges egy konzervált funkció elvégzése gyorsan evolválódó fehérjék segítségével. 


\section{Summary}

The most important molecular functions of a cell are usually performed by highly conserved proteins. Any mutation in these essential sequences could compromise the survival of the organism. However, in some cases the cells are seemingly tempting fate; they fulfil important functions by fast evolving proteins. In order to resolve this contradiction, we assume that these proteins may have an additional function, they contribute to species formation as post-zygotic barriers.

The hypothetical terminin complex is a fast evolving protein complex in Drosophila, which is responsible for the protection of the chromosomes termini, the telomeres. In eukaryotic cells telomeres prevent the chromosome ends from being detected as DNA double stranded breaks and also prevent chromosome shortening. In most organisms, this protective function is performed by the highly conserved shelterin protein complex. However, in Drosophila there are no homologues of shelterin proteins, instead a similar, still uncharacterized complex the terminin fulfil this role in chromosome end maintenance. Intriguingly, the members of terminin complex are fast evolving proteins. Their evolutionary speed and important cellular function make these proteins good candidates for having a role in post-zygotic isolation.

Terminin is believed to consist of HOAP, HipHop, Ver and DTL/Moi protein subunits. HP1 is generally regarded as the fifth subunit of the putative complex, though it is not strictly terminin-specific. While other terminin proteins localize only at chromosome ends, HP1 has a general role in maintaining chromosome structure. Furthermore HP1 is evolutionary highly conserved, while other terminin proteins manifest an accelerated rate of evolution. Deletion of the HP1 gene or any other terminin protein results in telomere fusions.

Physical interactions between terminin proteins have been demonstrated in vitro. According to these findings Ver interacts with DTL and HOAP, DTL interacts with Ver, HOAP and HP1. HipHop interacts with HP1 and HOAP, but it does not interact with Ver or DTL.

The available data about terminin proteins strongly suggest the existence of a shelterin like telomere capping complex in Drosophila; however, the existence of terminin is not experimentally proven, and no biochemical studies have been performed to investigate its assembly and action in detail.

As the first steps to characterize the terminin complex, we examined the rate of evolution of the whole proteins and their interacting domains. We collected and analysed the homologues sequences of the terminin genes from 21 Drosophila species. We found that the proteins and their interacting 
domains have accelerated evolution, which supports a possible role in speciation. Next, we created homology-based structure models. However, among the fast evolving terminin proteins only Ver resulted a reliable model. We evaluated this Ver model by the comparison of the structure and amino acid conservation rates. We have predicted the conserved amino acids that have a role in structure formation and nuclear localization. We also found further conserved surfaces that may contribute to DNA binding or may have a role in protein-protein interaction, although the roles of these surfaces are obscure.

In order to test how the fast evolving domains could maintain stable interactions we constructed multiple bacterial expression plasmids and produced the proteins of interest in bacteria. Ver, DTL, HOAP and HP1 was expressed in high levels, but HipHop expression was consistently low, and despite various attempts, which included alterations in construct design, conditions of induction and choices of host cells and trials of co-expression with other terminin proteins, we could not achieve notable expression. However, interaction data of terminin proteins suggest that a terminin complex may form without HipHop. The insolubility of Ver and DTL proteins during protein expression also delayed our attempt to reconstitute of the terminin complex. However, when we co-expressed these proteins with each other, their solubility increased suggesting that they are interacting partners.

We subjected the lysate of cells that co-expressed four heterologous proteins (HOAP, HP1, Ver and $\mathrm{DTL} / \mathrm{Moi}$ ) in soluble form to chromatography on heparin-sepharose column. We found that Ver together with DTL/Moi, and similarly HOAP together with HP1 eluted in different fractions, but no holo-complex was formed. The increasing salt concentration that we applied during the elution of our proteins, might disrupt terminin holo-complex, therefore we subjected peak fractions from the heparin-sepharose matrix to gel filtration column at low salt concentration. The gel filtration also revealed the existence of two terminin sub-complexes, the Ver-DTL and the HOAP-HP1 (and HipHop) sub-complexes. Our findings are in accordance with the literature since Ver and DTL are responsible for the inhibition of single stranded, while HOAP, HP1 and HipHop are responsible for inhibition of the double stranded break repairs.

We chose the Ver-DTL heterodimer for further studies, and we reconstituted Drosophila melanogaster Ver-DTL sub-complex by co-expressing them in bacteria. We successfully purified the sub-complex as described earlier. We also examined the DNA binding dynamics of the sub-complex, and we found that it binds single stranded DNA with a higher affinity than double stranded DNA. We also revealed that the Ver-DTL sub-complex has two DNA binding surfaces. Based on these results we suggest that both Ver and DTL have DNA binding activity. 
In order to investigate the role of Ver and DTL in speciation, we also created hybrid Ver-DTL subcomplex by the replacement of Ver with its orthologue from the closely related Drosophila yakuba. Both by gel filtration and immune affinity chromatography we found that Ver from $D$. yakuba and DTL from $D$. melanogaster could form a stable hybrid complex, despite the differences in their sequences. We examined the DNA binding properties of the hybrid sub-complex as well, and we got similar results as the $D$. melanogaster sub-complex. It binds single stranded DNA with higher affinity than double stranded DNA, and no loss of function was detected.

The formation of the hybrid complex suggests that the interaction between Ver and DTL may form on conserved surfaces. In this case, the accelerated evolution of amino acids does not affect the function of the protein, therefore it is unlikely that Ver and DTL have a role in species separation. However, our finding does not completely disprove this hypothesis.

Although our hypothesis about the terminin role in species formation remains unproven, we have successfully isolated two terminin sub-complexes. We have further studied the Ver-DTL heterodimer and its molecular function. This sub-complex also gave an opportunity to examine and solve the contradiction between the fast evolution and the important function of terminin proteins. We suppose that for the interactions between fast evolving proteins only a few amino acids are needed to be conserved, such as the amino acids that contribute to structure formation and the amino acids that form the interacting surfaces, while all the other parts of the molecule could change freely. In this case, fast evolution is not compromising the molecular function of the protein. 


\section{Függelékek}

\begin{tabular}{|c|c|c|c|c|}
\hline & HipHop & HipHop dupl & HipHop dupl & HipHop dupl \\
\hline Drosophila ananassae & GF10272 & - & - & - \\
\hline Drosophila biarmipes & $\begin{array}{l}\text { gi|358392949[690387- } \\
689698]\end{array}$ & $\begin{array}{l}\text { gi|358402098[2964671 } \\
\text {-2965297] }\end{array}$ & - & - \\
\hline $\begin{array}{l}\text { Drosophila } \\
\text { bipectinata }\end{array}$ & $\begin{array}{l}\text { gi|358403122[1284107 } \\
-1283427]\end{array}$ & - & - & - \\
\hline Drosophila elegans & $\begin{array}{l}\text { gi|343972741[1724994 } \\
-1725959]\end{array}$ & $\begin{array}{l}\text { gi|343972719[1005656 } \\
-1006243]\end{array}$ & $\begin{array}{l}\text { gi|343972552[34447- } \\
\text { 35022] }\end{array}$ & - \\
\hline Drosophila erecta & GG13678 & - & - & - \\
\hline Drosophila eugracilis & $\begin{array}{l}\text { gi|358409234[677060- } \\
\text { 676191] }\end{array}$ & $\begin{array}{l}\text { gi|358409002[154852- } \\
\text { 155409] }\end{array}$ & - & - \\
\hline Drosophila ficusphila & - & $\begin{array}{l}\text { gi|343464682[461020- } \\
\text { 461505] }\end{array}$ & $\begin{array}{l}\text { gi|343464675[185420 } \\
-184971]\end{array}$ & gi|343464569[2599414-2600109] \\
\hline Drosophila grimshawi & GH13489 & - & - & - \\
\hline Drosophila kikkawai & $\begin{array}{l}\text { gi|343973849[92534- } \\
\text { 92040] }\end{array}$ & - & - & - \\
\hline $\begin{array}{l}\text { Drosophila } \\
\text { melanogaster }\end{array}$ & CG6874 & CG14251 & - & - \\
\hline Drosophila miranda & $\begin{array}{l}\text { gi|478839164[177498- } \\
\text { 178172] }\end{array}$ & - & - & - \\
\hline $\begin{array}{l}\text { Drosophila } \\
\text { mojavensis }\end{array}$ & GI17239 & - & - & - \\
\hline Drosophila persimilis & GL24882 & - & - & - \\
\hline $\begin{array}{l}\text { Drosophila } \\
\text { pseudoobscura } \\
\text { pseudoobscura }\end{array}$ & GA19922 & - & - & - \\
\hline Drosophila rhopaloa & $\begin{array}{l}\text { gi|358405427[33547- } \\
\text { 32867] }\end{array}$ & $\begin{array}{l}\text { gi|358404732[683852- } \\
683265]\end{array}$ & $\begin{array}{l}\text { gi|358405183[799350 } \\
-800057]\end{array}$ & - \\
\hline Drosophila sechellia & GM14992 & - & - & - \\
\hline Drosophila simulans & GD14769 & GD21311 & - & - \\
\hline Drosophila takahashii & $\begin{array}{l}\text { gi|343974900[211517- } \\
\text { 212122] }\end{array}$ & $\begin{array}{l}\text { gi|343975433[141804- } \\
\text { 141217] }\end{array}$ & - & - \\
\hline Drosophila virilis & GJ17998 & - & - & - \\
\hline Drosophila willistoni & GK12110 & GK15167 & - & - \\
\hline Drosophila yakuba & GE19974 & - & - & - \\
\hline
\end{tabular}




\begin{tabular}{|c|c|c|c|c|}
\hline & HP1 & HOAP & HOAP dupl & DTL/Moi* \\
\hline Drosophila ananassae & GF15276 & GF16116 & - & $\begin{array}{ll}\text { GF26866 } & \text { (gnl|dana } \\
\text { scaffold_12911[2180058-2180635]) }\end{array}$ \\
\hline Drosophila biarmipes & $\begin{array}{l}\text { gi|449787801[45567- } \\
47741]\end{array}$ & $\begin{array}{l}\text { gi|449786593[384057- } \\
\text { 385042] }\end{array}$ & - & gi|459198444[1885228-1885814] \\
\hline Drosophila bipectinata & $\begin{array}{l}\text { gi|449794372[160543- } \\
\text { 161574] }\end{array}$ & $\begin{array}{l}\text { gi|449793788[682698- } \\
683645]\end{array}$ & - & gi|459198822 [894414-894995] \\
\hline Drosophila elegans & $\begin{array}{l}\text { gi|449802921[649465- } \\
\text { 650904] }\end{array}$ & $\begin{array}{l}\text { gi|449804487[352171- } \\
\text { 353093] }\end{array}$ & $\begin{array}{l}\text { gi } \mid 449804030[29779- \\
30841]\end{array}$ & gi|459200587[2176214-2176811] \\
\hline Drosophila erecta & GG23468 & GG11268 & - & $\begin{array}{l}\text { GG22804 } \quad \text { (gnl|dere } \\
\text { scaffold_4770[7553409-7554004]) }\end{array}$ \\
\hline Drosophila eugracilis & $\begin{array}{l}\text { gi|449842839[207145- } \\
\text { 208477] }\end{array}$ & $\begin{array}{l}\text { gi|449841379[49822- } \\
\text { 50703] }\end{array}$ & - & gi|459206134[433062-433656] \\
\hline Drosophila ficusphila & $\begin{array}{l}\text { gi|449814573[92535- } \\
94814]\end{array}$ & $\begin{array}{l}\text { gi|449814650[363262- } \\
\text { 364200] }\end{array}$ & - & gi|459201695[558770-559365] \\
\hline Drosophila grimshawi & GH10251 & GH18668 & - & $\begin{array}{l}\text { GH18562 } \\
\text { scaffold_14906[3589596-3590197]) }\end{array}$ \\
\hline Drosophila kikkawai & $\begin{array}{l}\text { gi|449823456[189636- } \\
\text { 191138] }\end{array}$ & $\begin{array}{l}\text { gi|449822549[182798- } \\
\text { 183676] }\end{array}$ & - & gi|459202742[386350-386937] \\
\hline Drosophila melanogaster & CG8409 & CG6219 & - & $\begin{array}{l}\text { CG42350 (gnl|dmel } 3 R[18255616- \\
18256211])\end{array}$ \\
\hline Drosophila miranda & $\begin{array}{l}\text { gi|478837874[12548- } \\
\text { 13409] }\end{array}$ & $\begin{array}{l}\text { gi|480995221[31717401- } \\
\text { 31718012] }\end{array}$ & $\begin{array}{l}\text { gi|480995221[17785649- } \\
\text { 17786505] }\end{array}$ & gi|480995221[11883980-11884582] \\
\hline Drosophila mojavensis & GI15430 & GI24179 & - & $\begin{array}{l}\text { GI24762 } \\
\text { scaffold_6540[17391024-17391636]) }\end{array}$ \\
\hline Drosophila persimilis & GL19396 & GL23417 & GL14051 & $\begin{array}{l}\text { GL21792 } \quad \text { (gnl|dper } \\
\text { scaffold_3[2121931-2122533]) }\end{array}$ \\
\hline $\begin{array}{l}\text { Drosophila } \\
\text { pseudoobscura } \\
\text { pseudoobscura }\end{array}$ & GA21056 & GA27250 & GA26940 & $\begin{array}{l}\text { GA26405 (gnl|dpse } 2[19388588- \\
19389190])\end{array}$ \\
\hline Drosophila rhopaloa & $\begin{array}{l}\text { gi|449556205[1289- } \\
\text { 2227] }\end{array}$ & $\begin{array}{l}\text { gi|449556302[11977- } \\
\text { 13060] }\end{array}$ & $\begin{array}{l}\text { gi|449571955[25331- } \\
\text { 25972] }\end{array}$ & gi|449575671[ 4792-5384] \\
\hline Drosophila sechellia & GM13138 & GM26573 & - & $\begin{array}{ll}\text { GM15294 } & \text { (gnl|dsec } \\
\text { scaffold_12[68564-69159]) } & \end{array}$ \\
\hline Drosophila simulans & GD22433 & GD21077 & - & $\begin{array}{lll}\text { GD19221 } & \text { (gnl|dsim } & \text { 3R[7399479- } \\
\text { 7400074]) } & & \end{array}$ \\
\hline Drosophila takahashii & $\begin{array}{l}\text { gi|449832232[14597- } \\
\text { 16758] }\end{array}$ & $\begin{array}{l}\text { gi|449831852[824922- } \\
825780]\end{array}$ & - & gi|459204027[774544-775127] \\
\hline Drosophila virilis & GJ17281 & GJ14215 & GJ17001 & $\begin{array}{lr}\text { GJ22548 } & \text { (gnl|dvir } \\
\text { scaffold_13047[19181152-19181777]) }\end{array}$ \\
\hline Drosophila willistoni & GK14980 & GK11387 & GK24325 & $\begin{array}{l}\text { GK28155 } \\
\text { scf2_1100000004921[3677794- } \\
3678394])\end{array}$ \\
\hline Drosophila yakuba & GE11133 & GE23460 & - & $\begin{array}{lll}\text { GE25528 } & \text { (gnl|dyak } & 3 R[2690898- \\
\text { 2691493]) } & & \\
\end{array}$ \\
\hline
\end{tabular}

94. 


\begin{tabular}{|c|c|c|c|c|}
\hline & Globin 1 & Lhr & Ver & Ver dupl \\
\hline Drosophila ananassae & GF16470 & GF13120 & GF10432 & - \\
\hline Drosophila biarmipes & $\begin{array}{l}\text { Dbia } \\
\text { gi|449786589[43960 } \\
8-440424]\end{array}$ & $\begin{array}{l}\text { gi|449787420[20219 } \\
\text { 5-203157] }\end{array}$ & $\begin{array}{l}\text { gi|449786027[98222 } \\
-98881]\end{array}$ & - \\
\hline Drosophila bipectinata & $\begin{array}{l}\text { gi|449793883[34705 } \\
-35272]\end{array}$ & $\begin{array}{l}\text { gi|449795434[22816 } \\
-23811]\end{array}$ & $\begin{array}{l}\text { gi|449794247[94863 } \\
-95495]\end{array}$ & - \\
\hline Drosophila elegans & $\begin{array}{l}\text { gi|449804144[5145- } \\
\text { 6022] }\end{array}$ & $\begin{array}{l}\text { gi|449803632[33178 } \\
\text { 6-332709] }\end{array}$ & $\begin{array}{l}\text { gi|449803332[23534 } \\
\text { 4-235982] }\end{array}$ & - \\
\hline Drosophila erecta & GG20278 & GG20678 & GG15580 & - \\
\hline Drosophila eugracilis & $\begin{array}{l}\text { gi|449841410[18440 } \\
\text {-19027] }\end{array}$ & $\begin{array}{l}\text { gi|449842111[14678 } \\
\text { 83-1468839] }\end{array}$ & $\begin{array}{l}\text { gi|449842806[63254 } \\
9-633196]\end{array}$ & - \\
\hline Drosophila ficusphila & $\begin{array}{l}\text { gi|449816899[12220 } \\
0-123232]\end{array}$ & $\begin{array}{l}\text { gi|449814461[50190 } \\
\text { 8-502864] }\end{array}$ & $\begin{array}{l}\text { gi|449814975[28421 } \\
\text { 9-284899] }\end{array}$ & - \\
\hline Drosophila grimshawi & GH13816 & GH21397 & GH14712 & - \\
\hline Drosophila kikkawai & $\begin{array}{l}\text { gi|449823214[44724 } \\
\text { 6-447832] }\end{array}$ & $\begin{array}{l}\text { gi|449824117[15457 } \\
\text { 5-155265] }\end{array}$ & $\begin{array}{l}\text { gi|449824548[12662 } \\
\text { 4-127289] }\end{array}$ & - \\
\hline $\begin{array}{l}\text { Drosophila } \\
\text { melanogaster }\end{array}$ & CG9734 & CG18468 & CG14121 & - \\
\hline Drosophila miranda & $\begin{array}{l}\text { gi|823757002[10502 } \\
\text { 3-105617] }\end{array}$ & $\begin{array}{l}\text { gi|478837310[26289 } \\
-27539]\end{array}$ & $\begin{array}{l}\text { gi|478839189[14445 } \\
\text { 4-145086] }\end{array}$ & - \\
\hline Drosophila mojavensis & GI24641 & GI18576 & GI12259 & - \\
\hline Drosophila persimilis & GL21726 & GL11424 & GL25197 & - \\
\hline $\begin{array}{l}\text { Drosophila } \\
\text { pseudoobscura } \\
\text { pseudoobscura }\end{array}$ & GA21995 & GA14945 & GA12773 & - \\
\hline Drosophila rhopaloa & $\begin{array}{l}\text { gi|449584828[14121 } \\
-14753]\end{array}$ & $\begin{array}{l}\text { gi|449561572[28509 } \\
-29444]\end{array}$ & $\begin{array}{l}\text { gi|449575535[28892 } \\
-29527]\end{array}$ & - \\
\hline Drosophila sechellia & GM25744 & GM21773 & GM25351 & - \\
\hline Drosophila simulans & GD20318 & GD11266 & GD14384 & - \\
\hline Drosophila takahashii & $\begin{array}{l}\text { gi|449833380[40505 } \\
\text { 0-405759] }\end{array}$ & $\begin{array}{l}\text { gi|449833601[44136 } \\
\text { 6-442292] }\end{array}$ & $\begin{array}{l}\text { gi|449833669[29715 } \\
\text { 5-297811] }\end{array}$ & - \\
\hline Drosophila virilis & GJ23463 & GJ20370 & GJ11490 & - \\
\hline Drosophila willistoni & GK11857 & GK22897 & GK12525 & GK14293 \\
\hline Drosophila yakuba & GE26348 & GE11661 & GE21909 & - \\
\hline
\end{tabular}

1. Függelék: A dolgozatban felhasznált gének azonosítói vagy a kódoló régiók pozíciói 21 Drosophila fajban. DTL/Moi esetén a Tgs1 génnel való közös transzkripció miatt az azonosítók mellett a pozíció adatokat is feltüntettük. 
DTL/Moi

A modell illeszthetősége a templátra

1 1

Valósznűség szín-kód

A másodlagos szerkezet predikció

Magas (9) | || || ||||| Alacsony (0)

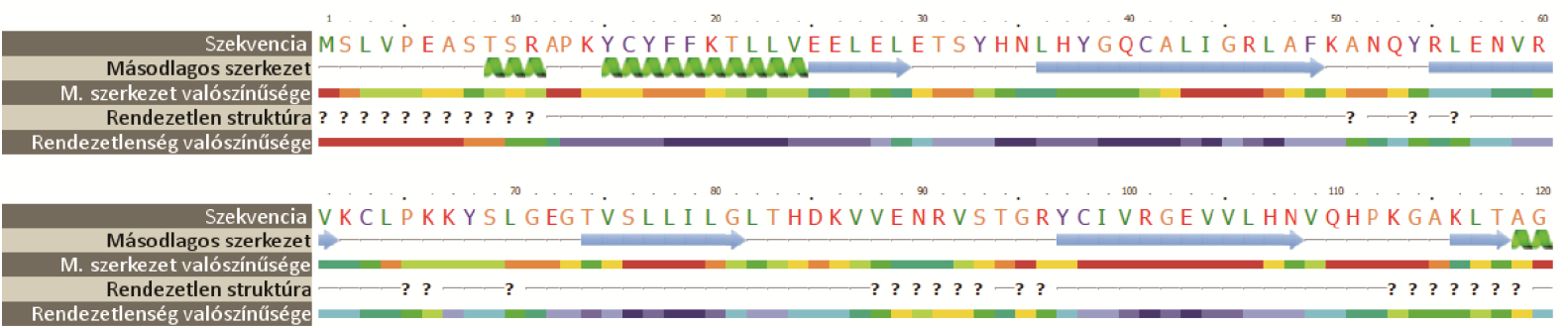

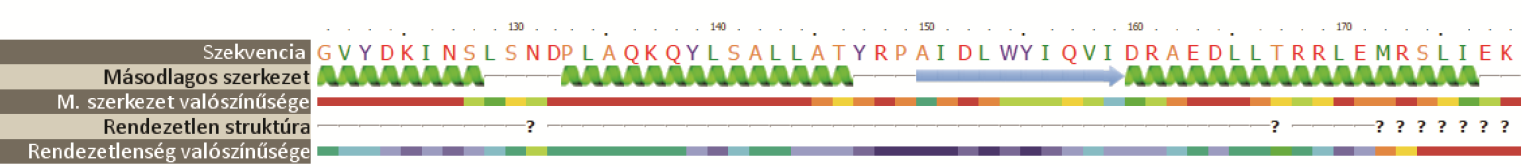

$$
\begin{aligned}
& \text { Valósznüség szín-kód } \\
& \text { Magas (9) } \\
& \text { ? Rendezetlen( } 23 \%) \\
& \text { ar. Alfa hélix ( } 30 \%) \\
& \Rightarrow \text { Béta redô }(33 \%)
\end{aligned}
$$

Egy prediktált térszerkezet, konzerváltság szerint színezve (szalag és felszín modell)
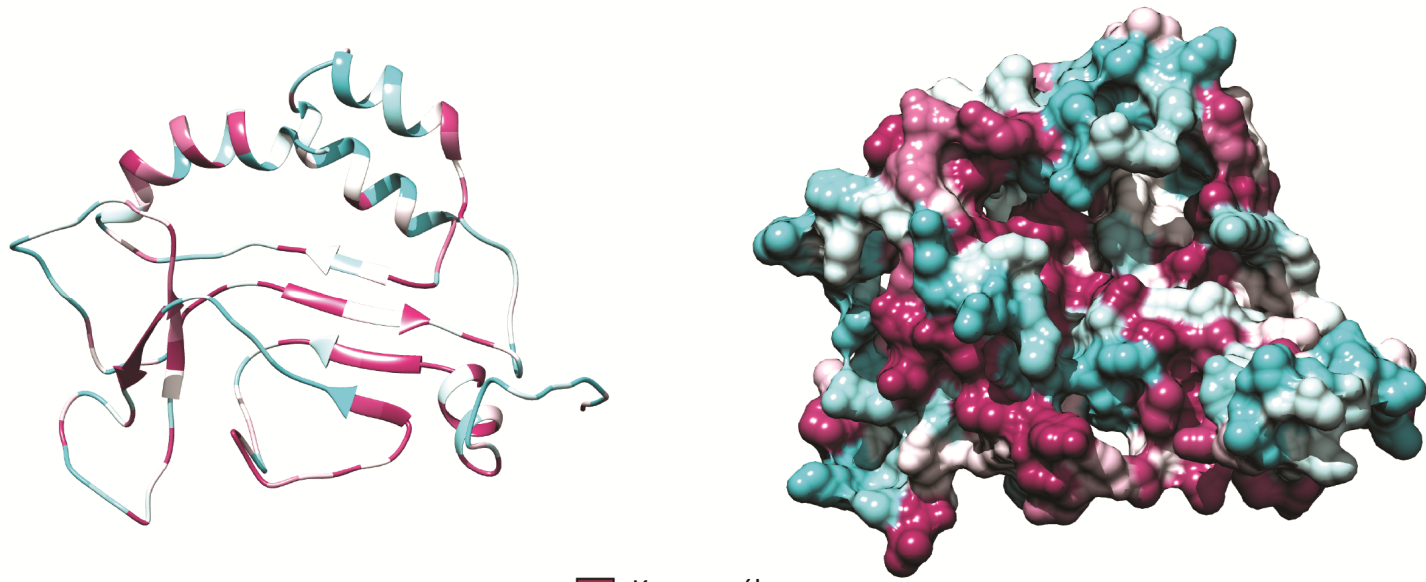

Konzervált

Variábilis

2. Függelék: Másodlagos és harmadlagos szerkezet predikciók Phyre2 szoftverrel DTL aminosav szekvenciájára. Habár a másodlagos szerkezeti elemek predikciója magas valószínűséget mutatnak, a kapott DTL térszerkezet nem megbízható. 
Ver

A modell illeszthetősége a templátra

1 IIIIII)

201 |||||||||||||||

Valósznűség szín-kód

Magas (9) | ||||||||||| Alacsony (0)

A másodlagos szerkezet predikció

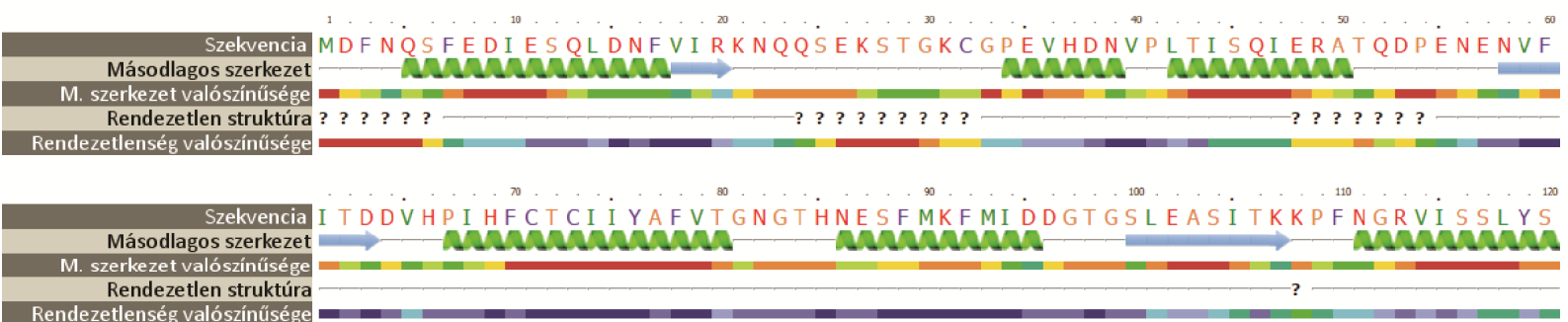
....... 170
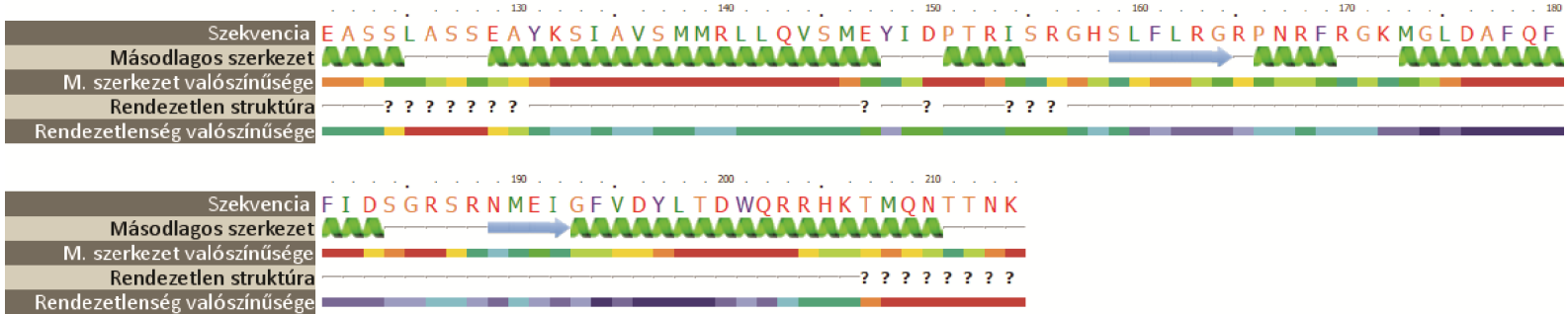

$$
\begin{gathered}
\text { Valósznúség szín-kód } \\
\text { Magas (9) } \\
? \text { Rendezetlen( } 20 \%) \\
\text { a Alfa hélix }(57 \%) \\
\Rightarrow \text { Béta redô }(13 \%)
\end{gathered}
$$

Egy prediktált térszerkezet, konzerváltság szerint színezve (szalag és felszín modell)
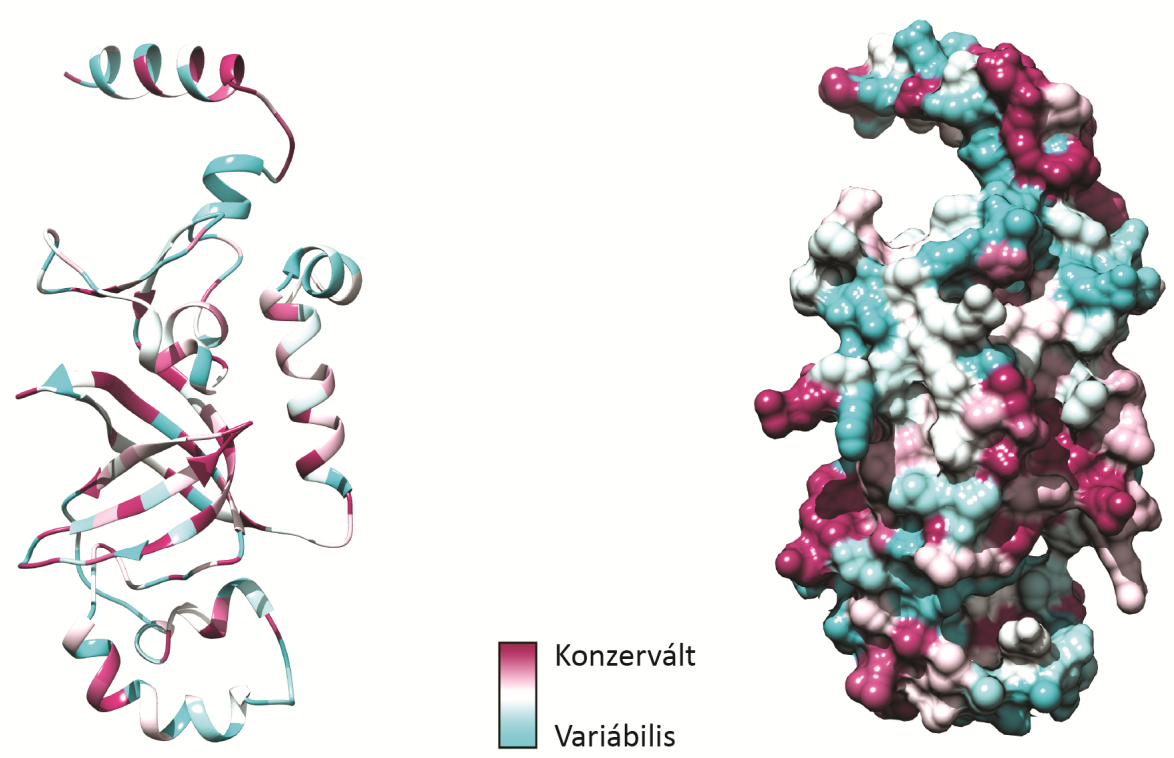

3. Függelék: Másodlagos és harmadlagos szerkezet predikciók Phyre2 szoftverrel Ver aminosav szekvenciájára. 
HOAP

A modell illeszthetősége a templátra

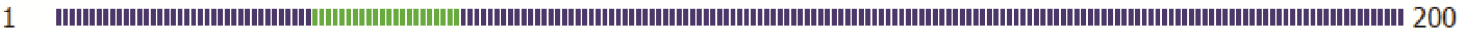

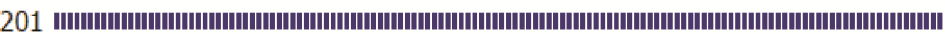

Valósznűség szín-kód Magas (9) |||||||||||| Alacsony (0)

A másodlagos szerkezet predikció

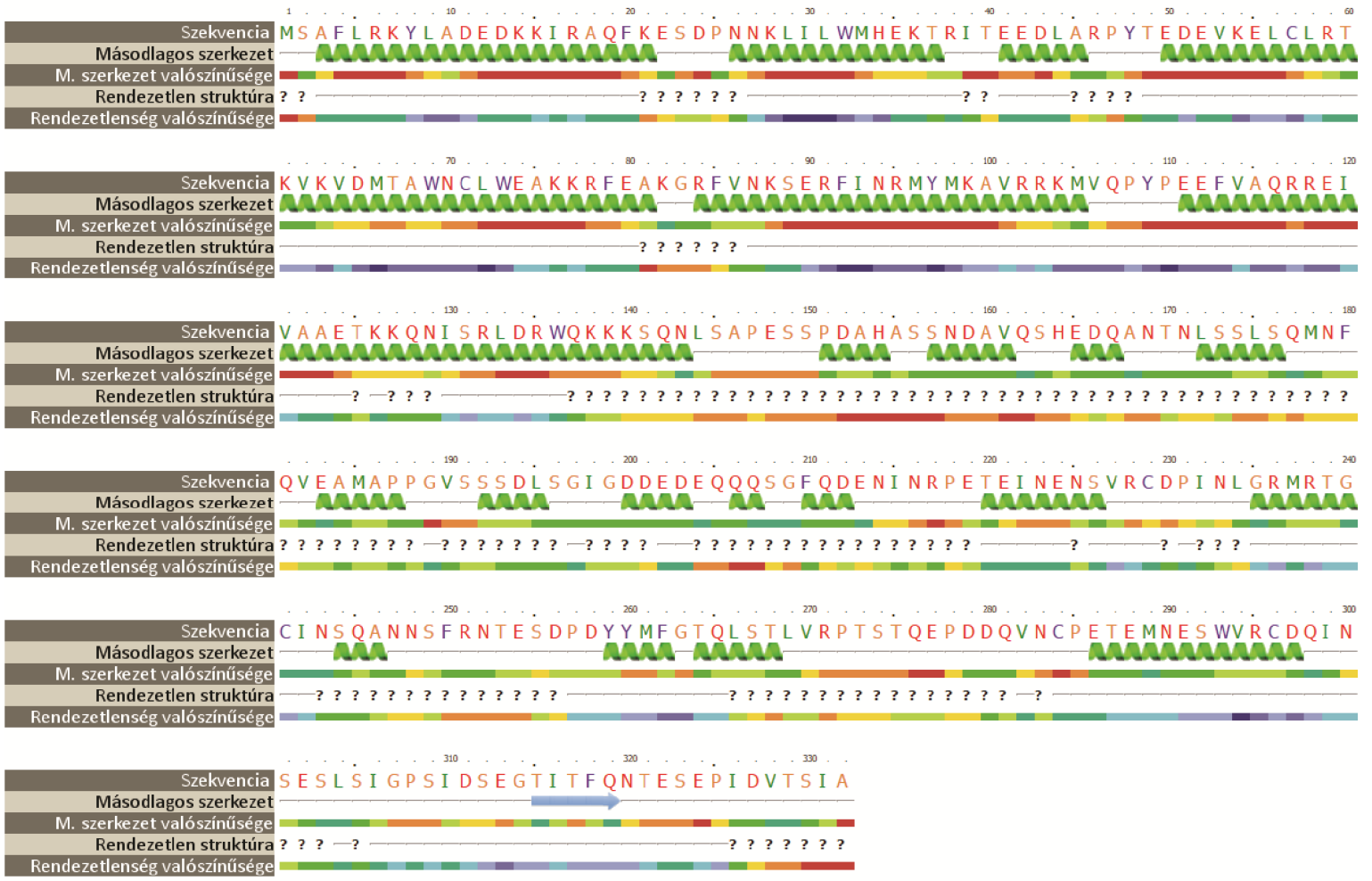

Valósznüség szín-kód

Magas (9) || || || || Alacsony (0)

? Rendezetlen( $45 \%$ )

Wa Alfa hélix ( $59 \%)$

Egy prediktált térszerkezet, konzerváltság szerint

$\Rightarrow$ Béta redố ( $2 \%$ )

színezve (szalag és felszín modell)
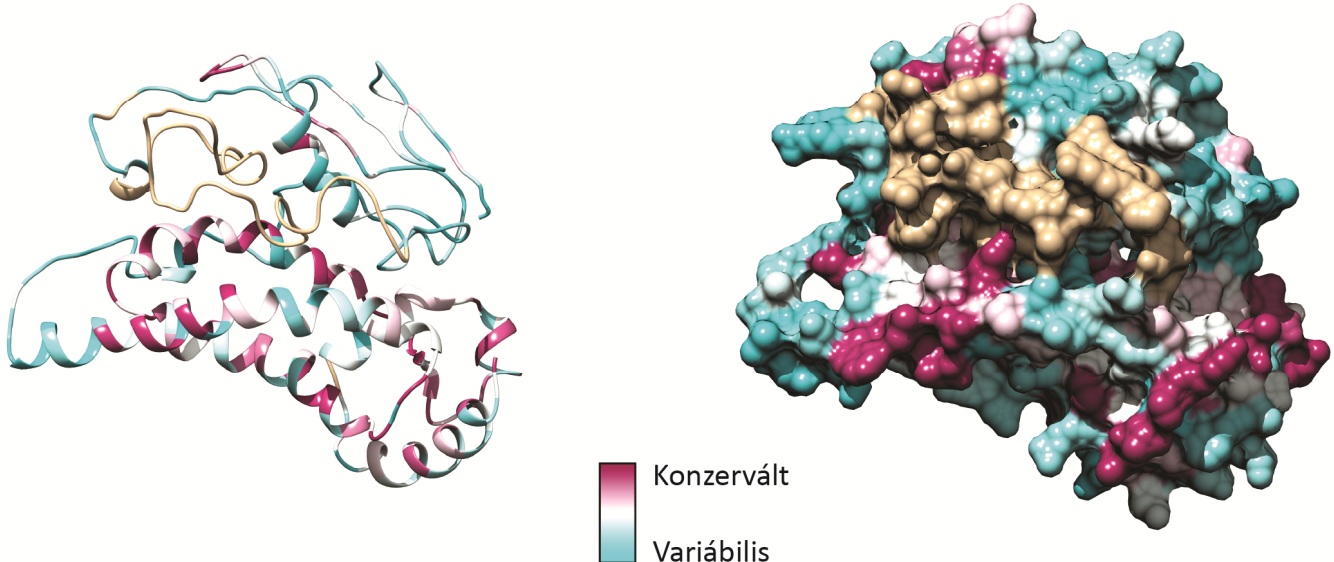

$\square$ Nem illeszthetó

4. Függelék: Másodlagos és harmadlagos szerkezet predikciók Phyre2 szoftverrel HOAP aminosav szekvenciájára. HOAP fehérje számos alfa helikális szerkezeti elemet tartalmaz, mely hélixek egyik felszíne konzerváltságot mutat. A prolinban gazdag doménben láthatunk egy inszerciót (barna), melyre konzerváltsági érték nem számolható. 
HipHop

A modell illeszthetősége a templátra

1 ก

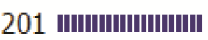

Valósznűség szín-kód

Magas (9) ||||||||||||| Alacsony (0)

A másodlagos szerkezet predikció

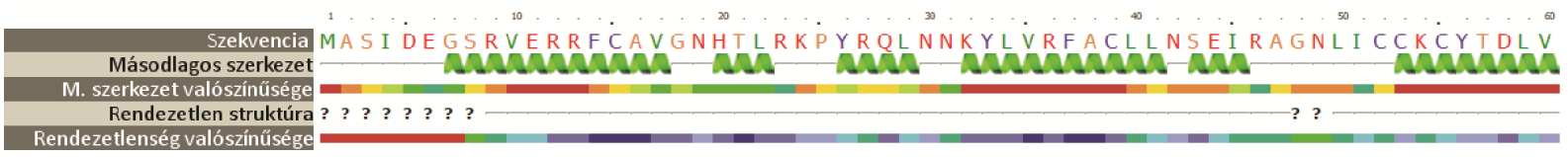

70

Szekvencia RL YRKKNDNAKRHKMARETAASI TDVSGSQSSSHQSAPSLHVSGQSSEFGASYSEGGIVT

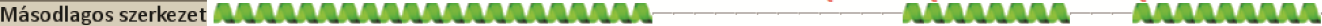
Rendezetlen struktúra $\quad$ ? ? ? ? ? ? ? ? ? ? ? ? ? ? ? ? ? ? ? ? ? ? ? ? ? ? ? ? ? ? ? ? ? ? ? ? ? ? ? ? ? ? ? ?

Rendezetlenség valószínüsége

(n)

150

Másodlagos szerkeze

TTSAA A I QKR QLARA N L MVKPSQRL S LAQTTPDCDDYDPNS

Rendezetlen struktúra ? ? ? ? ? ? ? ? ? ? ? ? ? ? ? ? ? ? ? — ? ? ? ? ? ? ? ? ? ? ? ? ? ? ? ? ? ? ? ? ? ? ? ? ? Rendeze

Szekvencia N L S L N A V NG T R L P H I Q P I P K R R P T VL D K Q S M D I Y L MG T T G G
Másodlagos szerkezet
M. szerkezet valószínúsége
Rendezetlen struktúra ? —? ? ? ? ? ? ? ? ? ? - ? ? —? ? ? ? ? ? ? ?
Rendezetlenség valószínúsége

Valósznüség szín-kód

Magas (9) |

? Rendezetlen(63\%)

a. Alfahélix (44\%)

$\Rightarrow$ Béta redô $(4 \%)$

Egy prediktált térszerkezet, konzerváltság szerint színezve (szalag és felszín modell)
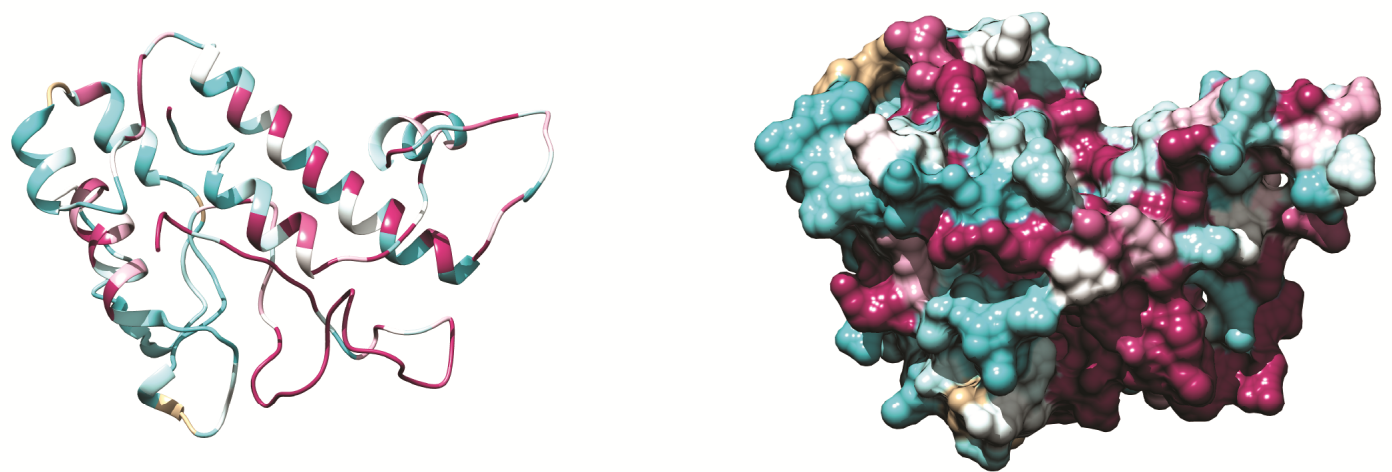

Konzervált

Variábilis

Nem illeszthető

Függelék 5: Másodlagos és harmadlagos szerkezet predikciók Phyre2 szoftverrel HipHop aminosav szekvenciájára. HipHop alfa-hélixeinek konzerváltságában hasonlít a HOAP hasonló szerkezeti elemeire. HipHop C-terminálisa erősen konzervált. Akárcsak HOAP esetében itt sem kaptunk megbízható térszerkezetet. 
A modell illeszthetősége a templátra

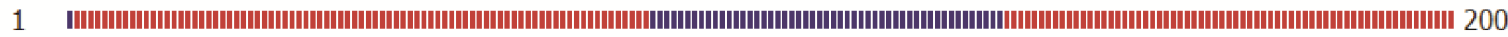
201 IIIIIII

A másodlagos szerkezet predikció
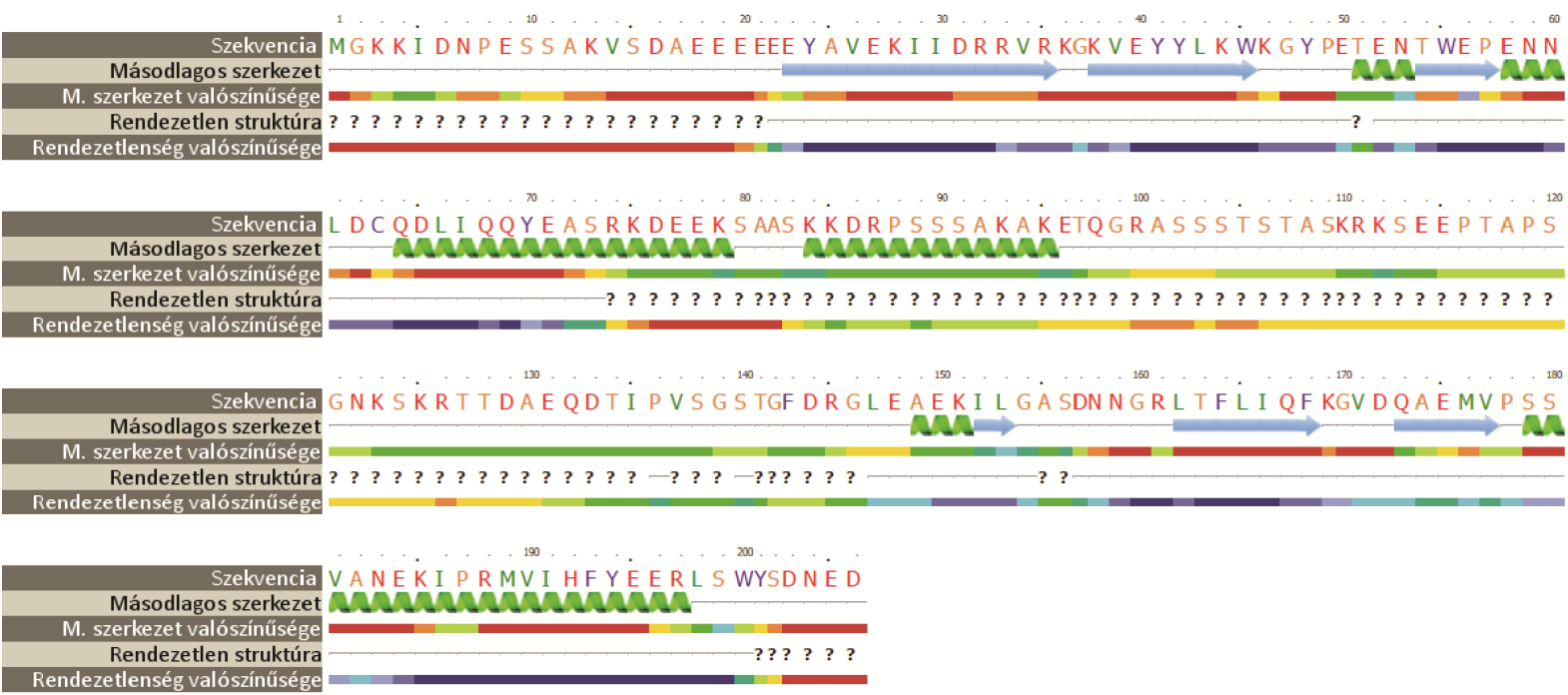

$$
\begin{gathered}
\text { Valóşníség szín-kód } \\
\text { Magas (9) } \\
? \text { Rendezetlen }(49 \%) \\
\text { a Alfa hélix }(27 \%) \\
\Rightarrow \text { Béta redô }(19 \%)
\end{gathered}
$$

Egy prediktált térszerkezet, konzerváltság szerint színezve (szalag és felszín modell)
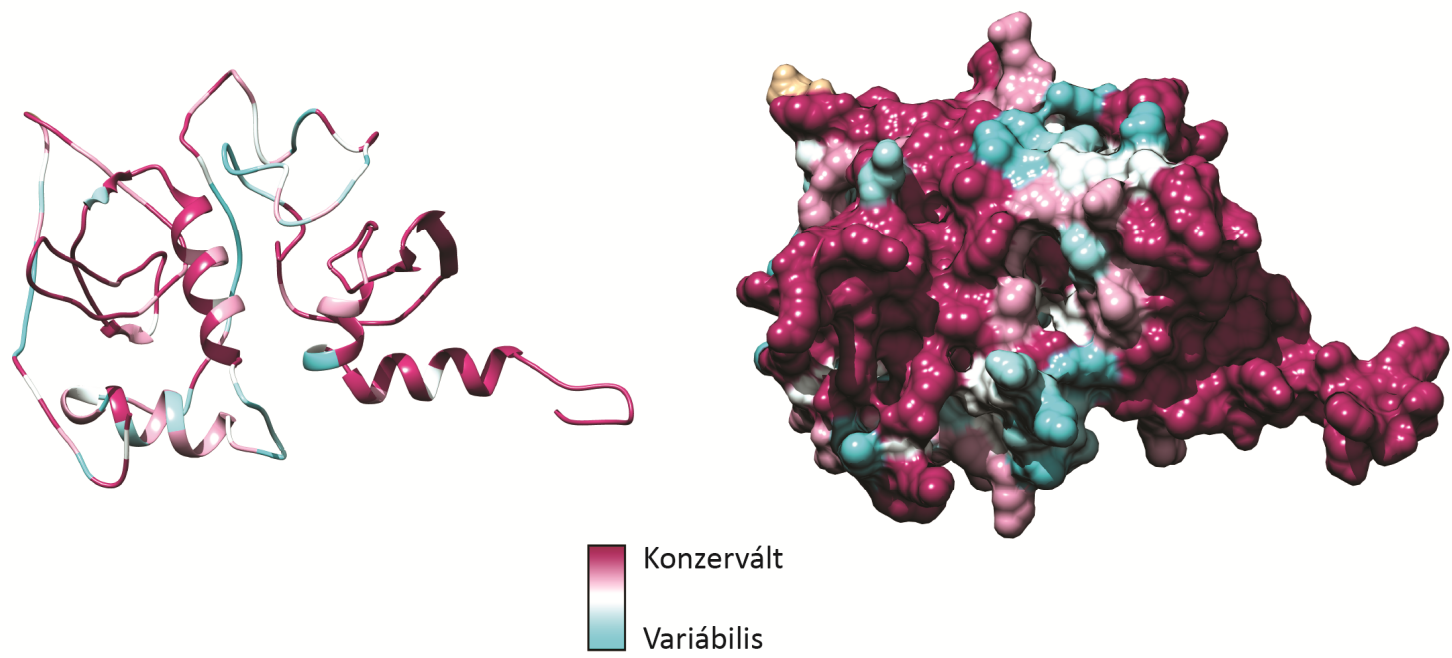

Nem illeszthető

Függelék 6: Másodlagos és harmadlagos szerkezet predikciók Phyre2 szoftverrel HP1 aminosav szekvenciájára. HP1 esetében kaptuk a legmegbízhatóbb szerkezeti predikciót. A két konzervált domén között lévő, rendezetlen másodlagos szerkezetet mutató, összekötő funkciót ellátó hinge régió térszerkezete nem megjósolható. HP1 fehérjének ez a doménje mutatja a legnagyobb változatosságot az evolúció során. 

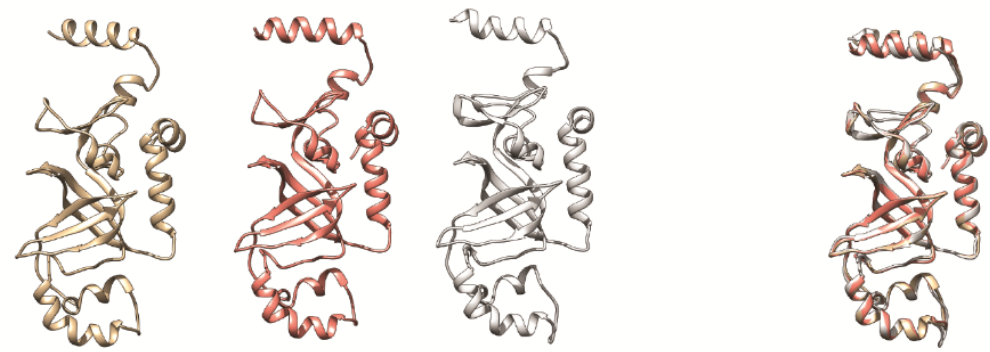

\begin{tabular}{|c|c|c|c|c|}
\hline & GA341 & zDOPE & RMSD & 3,5A átfedés \\
\hline D.yak & 1,00 & 0,27 & 7,927 & 0,493 \\
\hline D.gri & 1,00 & 0,58 & 8,059 & 0,461 \\
\hline
\end{tabular}

Függelék 7: D. melanogaster Ver P1 modellhez MODELLER-rel illesztett szerkezetek és hasonlósági értékek. A hasonlósági értékeket a MODELLER szoftver számolta négy féle megközelítést alkalmazva. A GA341 értékek 0 és 1 között változnak, minél közelebb van ez az érték az 1-hez annál hasonlóbbak a szerkezetek. A zDOPE (normalized discrete optimized protein energy), az RMSD (root-mean-square deviation) értékek esetén a kisebb számok jelentenek nagyobb egyezést a modellek között. A 3,5A átfedés a két térszerkezeten egymásnak megfeleltethető, azon alfa-szénatomok arányát mutatja, melyek 3,5A távolságon belül vannak az egymásra illesztett modelleken. 
A)

\section{Inp Áf $1 \quad 2 \quad 3 \quad 4 \quad 5$}

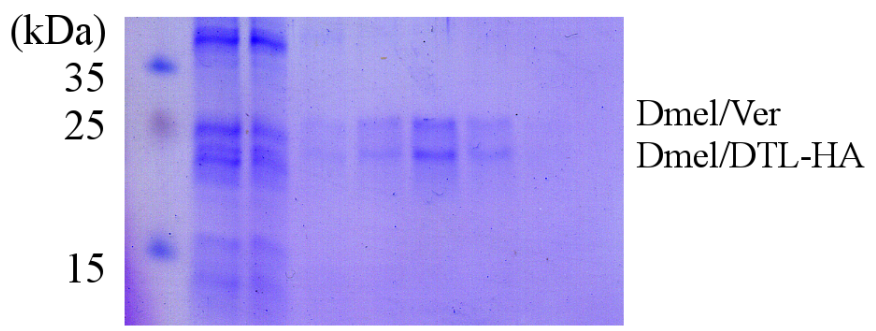

B)

L Inp Áf $1 \begin{array}{lllll}1 & 2 & 3 & 4 & 5\end{array}$

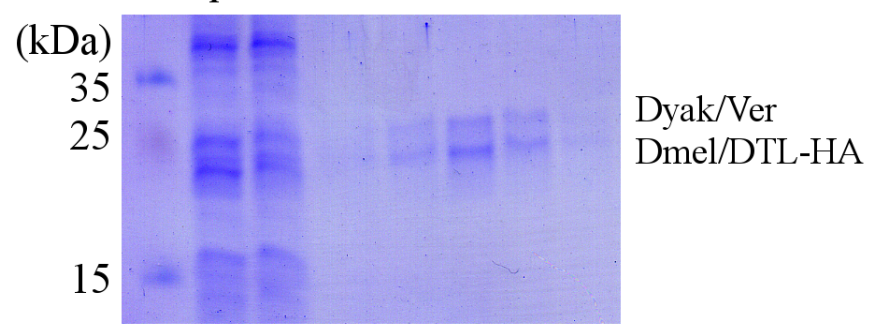

8. függelék: $D$. melanogaster Ver és DTL, illetve D. yakuba Ver és D. melanogaster DTL is stabil komplexet alkot, melyet immunaffinitás kromatográfiával is megerősítettünk.

A heparin-sepharose oszlopon tisztított $D$. melanogaster és hibrid Ver-DTL-HA dimereket (Inp) immunaffinitás kromatográfiával tovább tisztítottuk. A kromatográfiás oszlop felszínén lévő HA elleni ellenanyag telítődött a kísérletek során ezért az átfolyó (Áf) mintákban is látható Ver és DTL fehérje. Az oszlopról nagy koncentrációjú HA peptiddel történ az elúció mely peptidek leszorították a felkötődött DTL-HA fehérjét (1-5. frakciók). Habár az ellenanyag csak HA epitópot ismer fel, azaz csak a DTL fehérjét kötötte az eluálódott frakciókban megjelent a DTL-lel kölcsönható Ver fehérje is. Tehát mind (A) D. melanogaster Ver mind (B) D. yakuba Ver együtt tisztult DTL-HA fehérjével haemagglutinin immunaffinitás kromatográfia során.

L: molekulatömeg marker (létra); Inp: input, Áf: átfolyó; a számok a gyűjtött frakciókat jelölik. 
A)

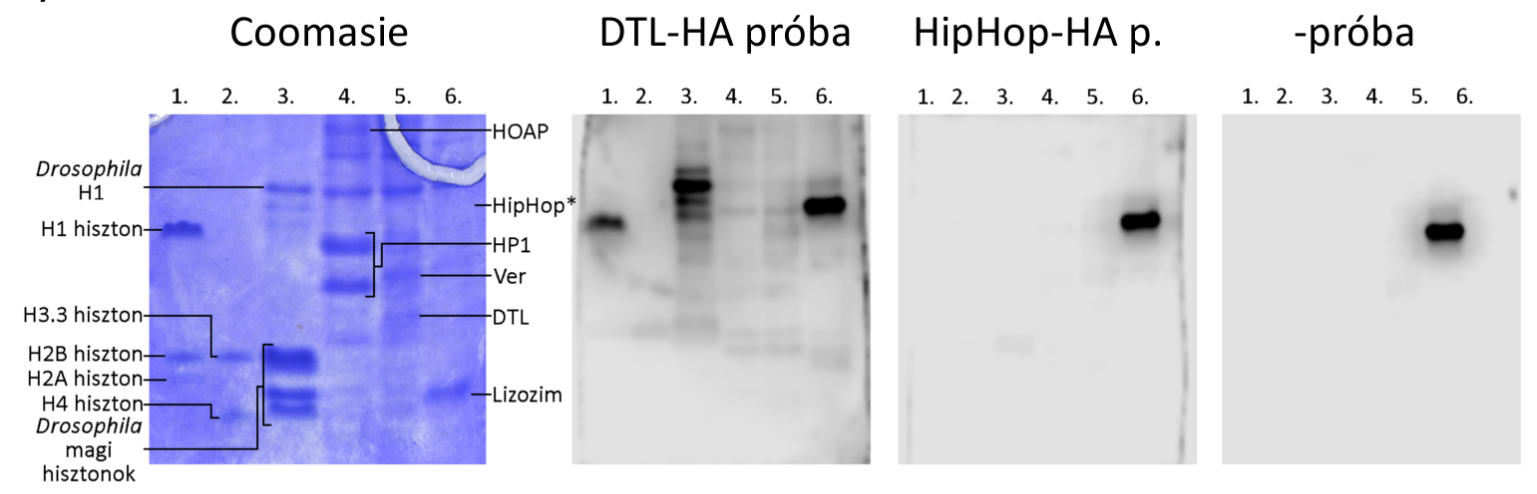

B)

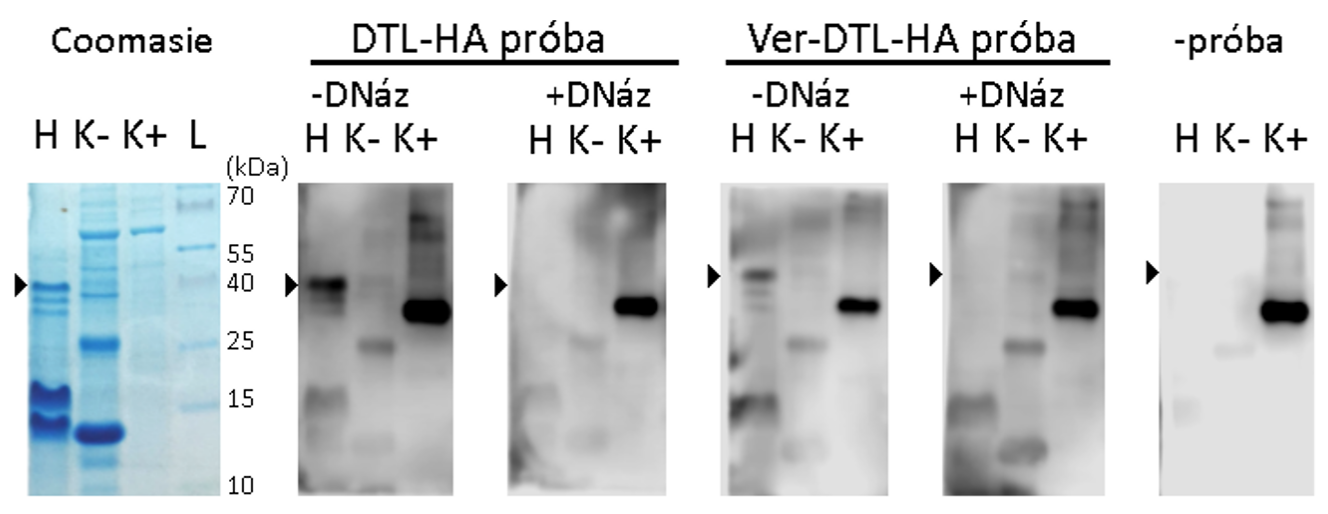

9. függelék: A DTL és a Ver fehérjék nem hatnak kölcsön far-western blot kísérletek során, azonban a DTL DNS intermedieren keresztül hat kölcsön $\mathrm{H} 1$ hisztonnal.

A far-western blot során, a western blot kísérletekhez hasonlóan, a vizsgált fehérjéket denaturáljuk, és méret szerint elválasztjuk, majd egy membrán felületen megkötjük őket. A western blot technikától eltérően, ebben az esetben ellenanyag helyett először az úgynevezett próbafehérjével kezeljük a mintát, mely potenciálisan köt a membránon lévő kölcsönható partneréhez. A fehérje-fehérje interakciót a próbafehérje elleni ellenanyaggal mutatjuk ki.

(A) $\mathrm{Az}$ A) panelen látható far-western blot kísérleteket baculovírus rendszerrel termeltetett DTL (D. melanogaster) fehérje és baktériumban előállított HipHop fehérje felhasználásával végeztem. A $D$. melanogaster terminin proteinek mellett hiszton fehérjéket is vizsgáltunk, mint potenciális interakciós partnerek. A far-western blot kísérlet eredményeként nem tapasztaltunk kimutatható kölcsönhatást a Ver és a DTL fehérjék között. Feltételezésünk szerint a Ver a denaturációt követően képtelen volt visszanyerni natív térszerkezetét, így az interakciós felszíne sem alakulhatott ki.

Coomassie: Coomassie brilliant blue festett SDS-PAGE, mely a membránra felvitt fehérjéket és a gélben jellemző helyzetüket mutatja. 1: Hiszton1, H2B, H2A, 2: H3.3, H4, 3: Drosophila hiszton preparátum, 4: HOAP, HP1, 5: Ver, DTL, 6: lizozim, HipHop-HA.

(B) A H1 hiszton esetében tapasztalt jel DNS intermedieren megvalósuló interakció miatt alakult ki. Far-western blot kísérletek DTL-HA és Ver-DTL-HA próbákkal történtek. DNáz kezelés hatására nem alakult ki interakcióra utaló jel a kísérlet során. A nyílhegyek a $\mathrm{H} 1$ hisztont jelölik. Az aspecifikus jelek a próba nélküli membránon is megfigyelhetőek. H: Drosophila hisztonok, K-:lizozim és BL21 sejt extraktum, K+: HipHop-HA 


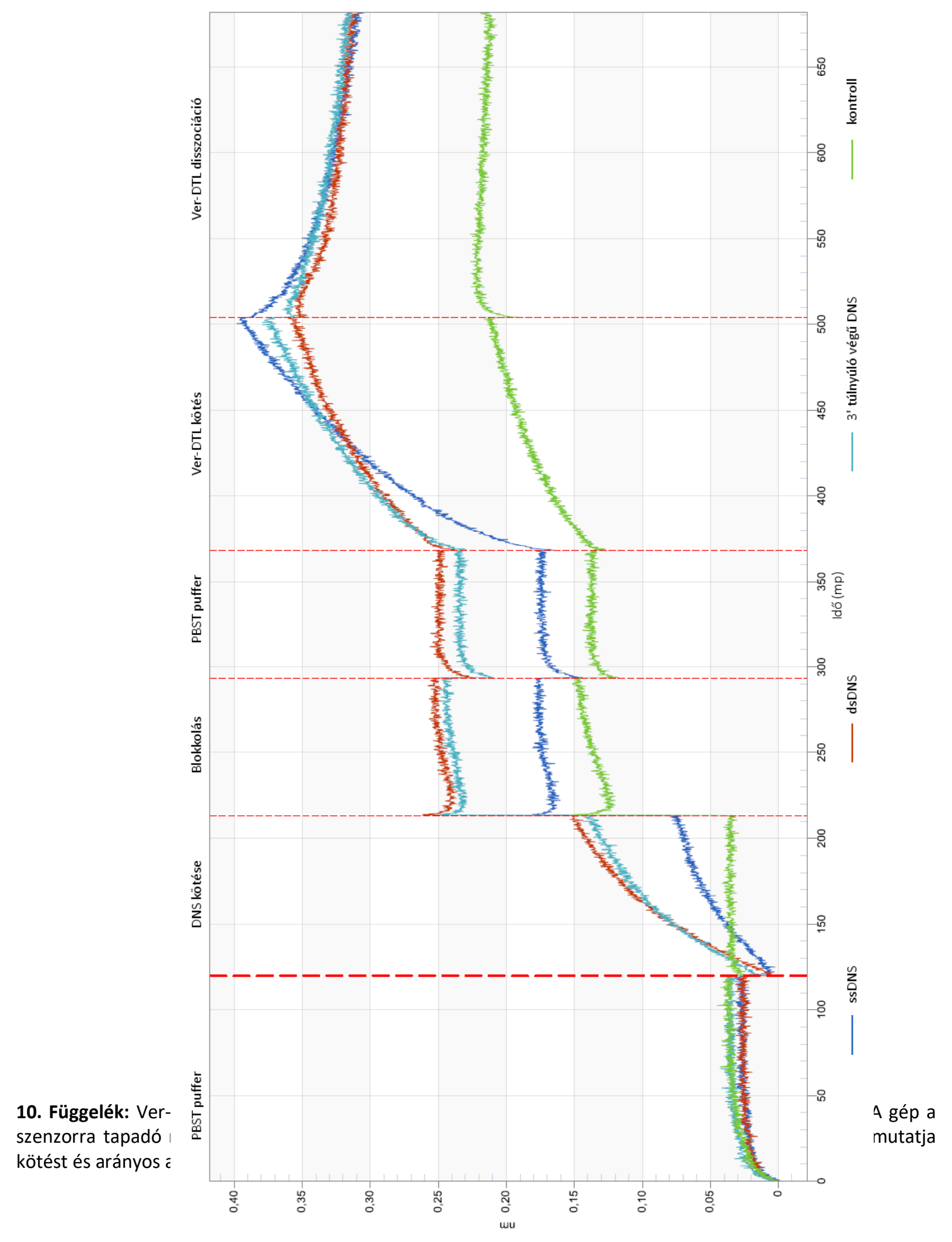




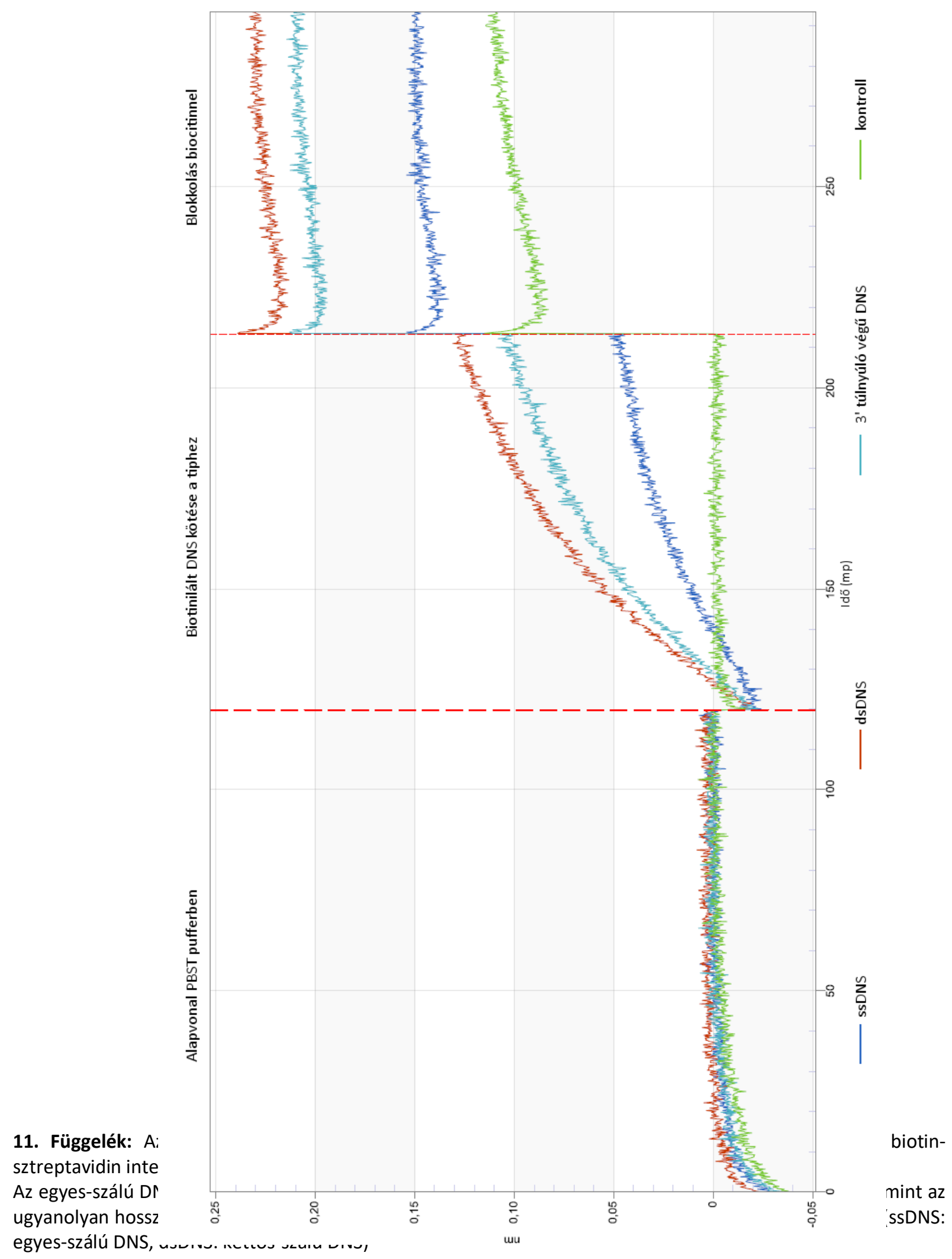

